Historic, Archive Document

Do not assume content reflects current scientific knowledge, policies, or practices. 


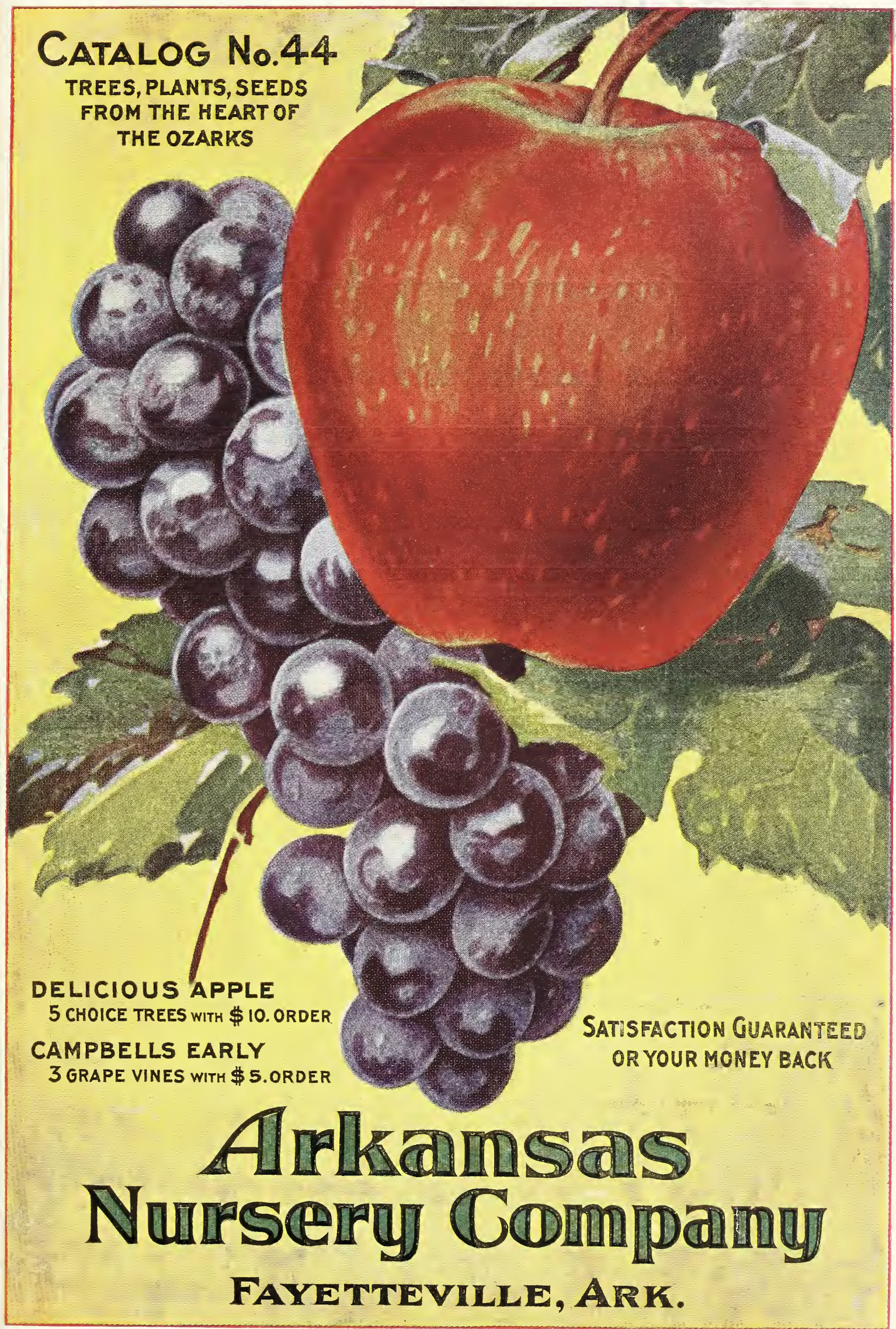




\section{THE DELICIOUS APPLE}

Five Cholce Trees of This Variety Sent Free With Every Order Amounting to $\$ 10.00$

UCCESSFUL wher ever apples grow. Delicious always shows a profit. Season after seasor. Delicious tops the market. 'There's satisfaction in growing it, because of its unequaled quality, and profitable hecause of the demand for it. "The man who has an o r c h a r made up largely of Delicious worries less uliout his other crops.

Its luscious flavor. delightful crispiness and mild, yet spicy juice appeal to all, splendid keeper.

Its $\mathrm{rem}$ a $\mathbf{r}^{\mathrm{k}}$ y b le flavor, it great lieauty and unusual shipping qualities, $t h e$ vigor, productiveness and the nardiness of the tree put Delicious in a clas by itself.

The planting of Delicious orchards have proven a profitable in. vestment to thousands of successful f $r u$ it growers throughout the Unit e d States, Start a good sized Delicious orchard thi year and share in the profits derived from the growing of this remarkable apple.

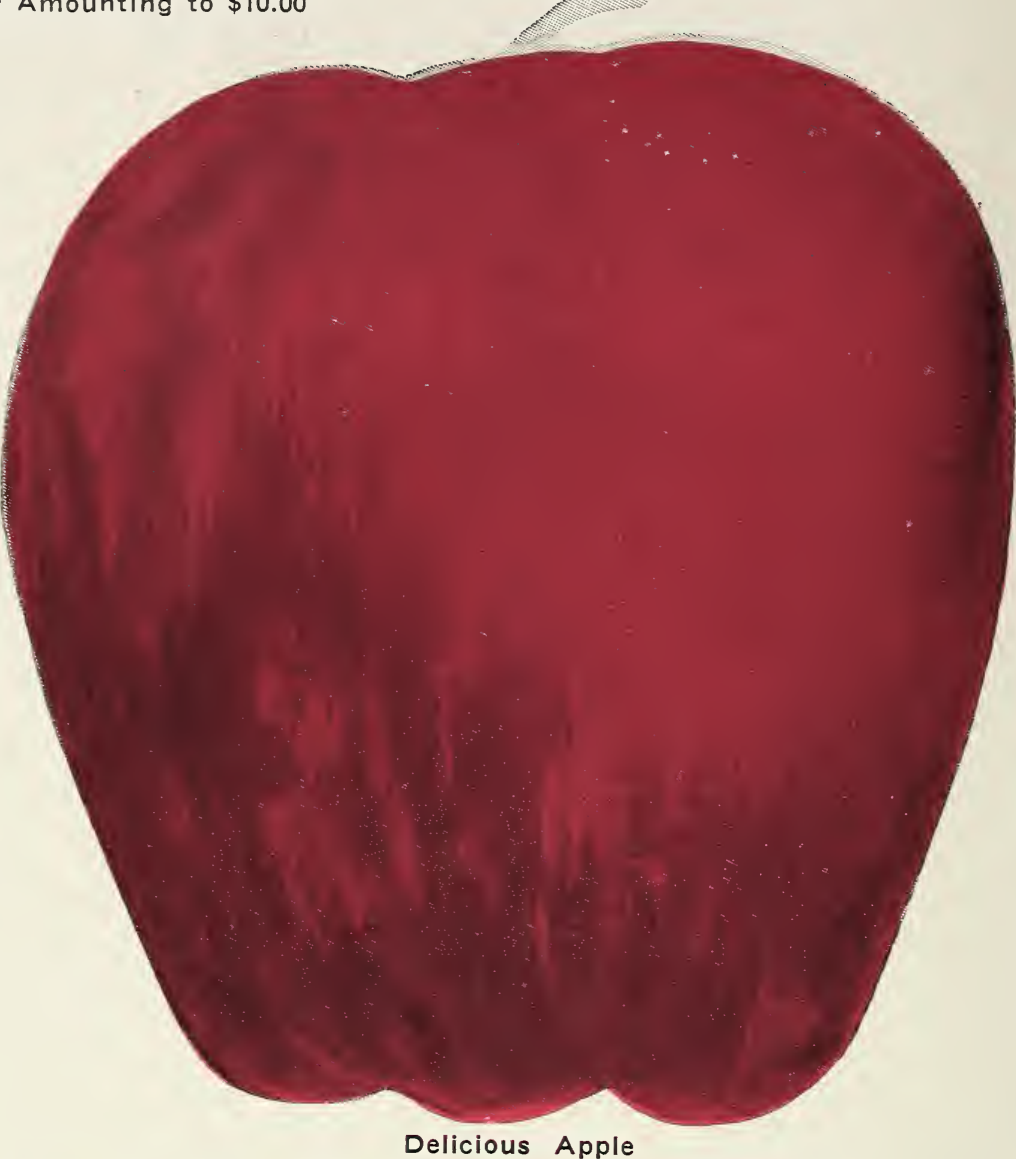

Here are the remarkably low prices we are making on these fine Ozark grown Delicious apple trees:
2 to $3 \mathrm{ft}$. trees, each $30 \mathrm{c}$
10 for $\$ 2.50$
3 to $4 \mathrm{ft}$. trees, each $40 \mathrm{c}$
10 for $\$ 3.50$
100 for $\$ 20.00$
4 to $5 \mathrm{ft}$. trees, each $50 \mathrm{c} \quad 10$ for $\$ 4.50$
for $\$ 30.00$
100 for $\$ 40.00$

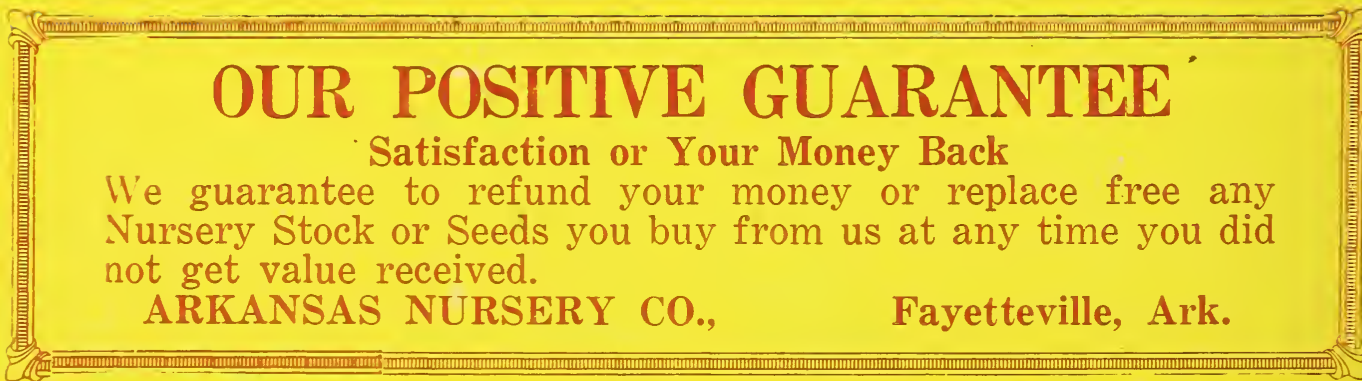

ARKANSAS NURSERY COMPANY,

Tulsa, Okla., September 26, 1921.

Fayetteville, Arkansas

Gentlemen: You are business people of your word. I wish to acknowledge the receipt of the deed to forty acres of land in Johnson County, Arkansas, and I certainly appreciate the prize for sending the largest order during 1921. You have also lived up to your reputation for dependable nursery stock and I wish to say that the stock sent me was highly satisfactory.

Assuring you of my future business, I desire to remain $\begin{array}{ll}\text { Yours very truly, } & \text { C. M. MURPHREE, }\end{array}$

1101 East 2d St., Tulsa, Okla.

All orders for Nursery Stock to the amount of $\$ 5.00$ or more are sent charges prepaid. If your order is less than $\$ 5.00$ and you wish it sent by parcel post or prepaid express add $10 \mathrm{c}$ to each dollar to prepay charges. 

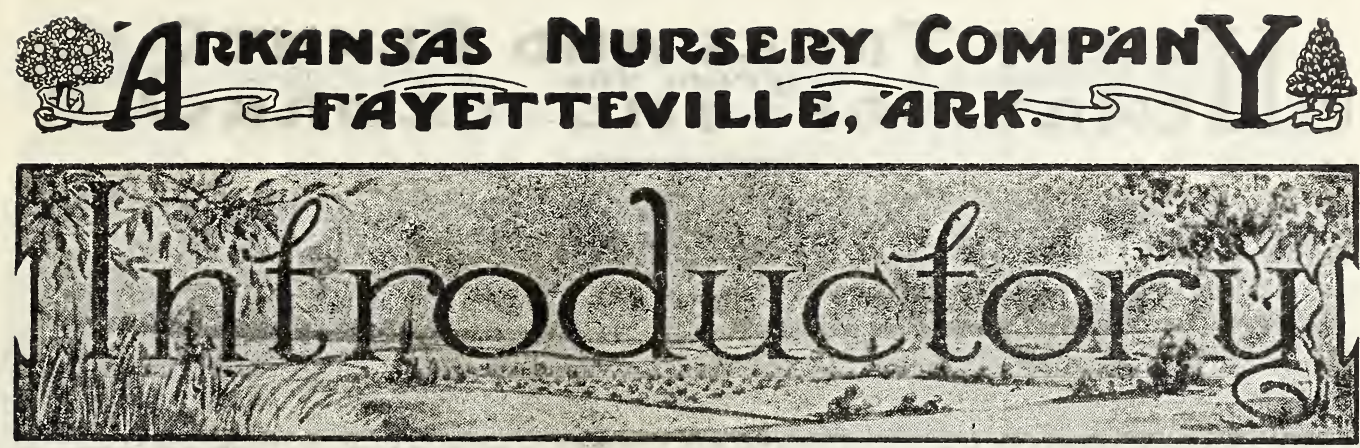

\section{South Planting Millions of Fruit Trees and Small Fruits}

TWHE South is planting more fruit trees and small fruits this year than ever before in its

history. The demand has never been so great for small fruits and fruit trees. The reason is simple enough. Farmers and bankers alike are agreed that it is both practical and profitable to raise more fruit. Many who never before planted small fruits are putting in an acre or so of berries this year.

Fortunately, we anticipated just this condition, and consequently have grown millions of trees and will be able to supply every demand of the 50,000 families who read this catalog. We have grown more apple trees and strawberry plants than ever before and offer your choice of varieties at prices that are right.

\section{ARKANSAS STATE PLANT BOARD Office of the Chief Inspector LITTLE ROCK}

\section{Certificate of Nursery Inspection}

No. Cs 1921-1922 Issued Aug. 27, 1921

This is to certify that, in accordance with the provisions of the Arkansas Plant Act of 1917, the nursery and premises thereof belonging to Arkansas Nursery Company, of Fayetteville, Arkansas, have been inspected by a duly authorized inspector and were found to be substantially free of injurious insect pests and plant diseases and that, as a condition of the issuance of this certiflcate, the owner or operator of such nursery has agreed to comply with such requirements as the Chief Inspector has prescribed for the elimination of infested or diseased trees or plants, and has further agreed not to dispose of any nursery stock unless it is covered by a certificate granted by the Chief Inspector of the Arkansas State Plant Board.

This certificate is not transferable and may be revoked for cause.

This certificate expires Sept. 1, 1922.

GEO. B. BECKER,

Chief Inspector.

\section{Why the Home Fruit Garden?}

A more general culture of fruits in gardens and in home orchards would contribute substantially to the health and pleasure of the average family, besides furnishing a supply of valuable food products at a relatively small outlay of money.

In many localities the difficulty incident to securing fruit in pleasing variety by purchase is an added reason for its home production wherever possible.

A sufficient range in variety of fruits can be produced throughout a large portion of the country to provide a supply in the fresh state for the table during a large part of the year and for canning or otherwise conserving for use when desired.

This bulletin deals with those widely grown fruits, such as the apple, peach, pear, and plum, which are commonly called deciduous. These fruits, with few exceptions, are borne on plants which shed their leaves annually and $m$ st be dormant for a period during each year in order to thrive. They become dormant in most cases through the influence of low temperatures. From Bulletin U. S. Dept. Agriculture.

\section{The Point of View}

The commercial grower thinks and operates in terms of his orchard, carload shipments of fruit, and market prices. The one who grows fruit for home use thinks in terms of individual trees or plants and works to secure a supply for family use. The commercial grower measures his success principally by the effect of his bank account; the one who grows fruit for home use, by the regularity and quality of the supply that comes to his table and the satisfaction derived from having it fresh and tree ripened and the product of his own efforts.

The ideal fruit garden or home orchard should contain several different kinds of fruit, represented in many cases by a considerable number of varieties ripening one after another over a long period. Large yields, good shipping quality, and attractiveness in appearance may be made secondary to high dessert quality or special excellence for cooking purposes. -From U. S. Dept. Agriculture Bulletin.

\section{HOW TO ORDER-IT'S EASY}

All orders for $\$ 5.00$ or more are sent charges prepaid. If your order is less than $\$ 5.00$ and you wish it sent by parcel post or prepaid express, add $10 \mathrm{c}$ to each dollar to prepay charges. 

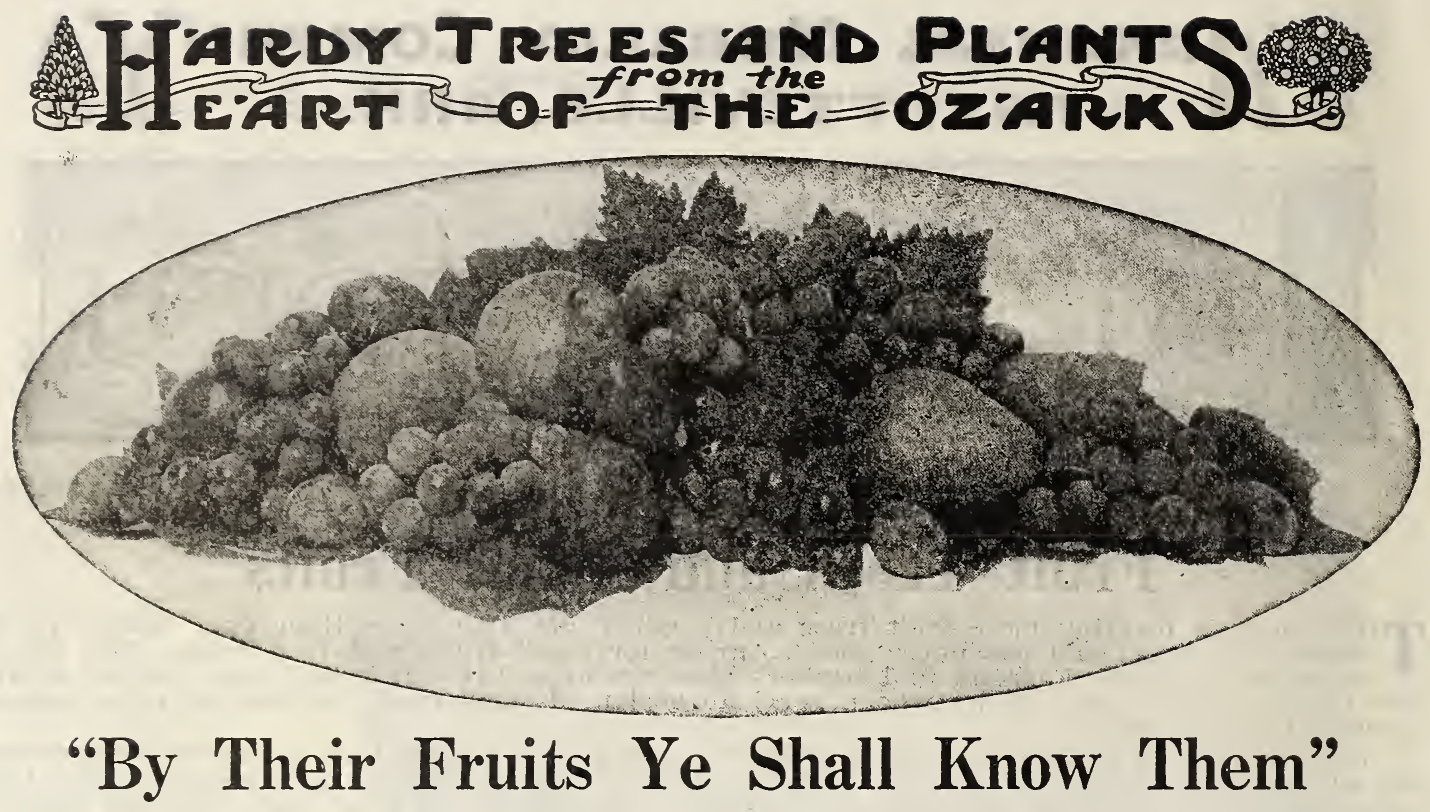

\section{Plant Hardy Trees and Plants "From the Heart of the Ozarks"}

WE GROW our own trees and plants on our own land in Arkansas. Our big modern packing houses and nursery grounds comprise the largest nursery concern in the State of Arkansas and the Southwest. We are located at Fayettville, in the northwestern part of the state, on the main line of the St. Louis \& San Francisco railroad, running between St. Louis and Texas points.

Some of our nursery farms adjoin the right-of-way, and the buildings are provided with special facilities for handling rush orders.

Fayettville is almost the geographical center of the most wonderful fruit growing district in the central United States.

The government reports unusual growth of fruit trees in this region.

\section{It Is Easy to Order}

We have tried to make it easy for you to make out your order from this catalog. You do not have any zone rates, express or freight rates to figure out. All you have to do is to make out a list of the varieties you want and send check for the amount. The stock goes to you by prepaid parcel post, express or freight, whichever manner of shipment you indicate on your order. If your order does not amount to $\$ 5.00$ add $10 \mathrm{c}$ on each dollar to prepay the postage. For instance, if you send an order amounting to $\$ 3.50$, you should add $35 \mathrm{c}$ for postage.

\section{Time of Shipment}

Many people who order Trees, Plants and Seeds from some Nurseries do not get their order when they want it. We can most always send out shipments at any time wanted as we have fine facilities for handling our stock. We have large frost proof packing houses and are advantageously located for shipping both North and South.

\section{Order Early-It Will Pay You}

Many people who postpone until the last moment to place their order fail to get their stock. Be sure to place your order early so that you can get what you want and get it planted at the proper time.

\section{How We Ship}

It makes no difference where you are located, we can guarantee safe arrival of your plants. Last season we sent orders to far away Honolulu and other foreign countries: to all of the states and into Canada. We can reach you by parcel post, express or freight. We send out nearly all small orders by parcel post. It is very important for you to indicate on the order blank how you want shipment made. If you live off of the railroad and not convenient to the express office, we can send your order by parcel post unless it be a very large shipment; but if you live convenient to the express office and you have a medium sized order it is best that it be sent by express. We have the best facilities for packing to insure your stock reaching you in perfect condition.

\section{Planting Instructions}

We send with each order brief directions for planting, but we will at all times cheerfully give you any information desired as to the planting, cultivating, spraying, or pruning. It is to our interest to see that you make a success of the stock that you purchase from us and we issue bulletins and instructions on the various things pertaining to the growing of trees and plants and will be glad to send free to all customers requesting them or give any special information desired.

\section{How to Make Remittance}

Checks look good to us. Do not go to the trouble or expense to buy a money order but send your personal check. This is a good receipt and the safest way of making remittance. If you do not care to send check it would be better to buy money order than to 


\section{ARANSAS Nursery COMPANY}

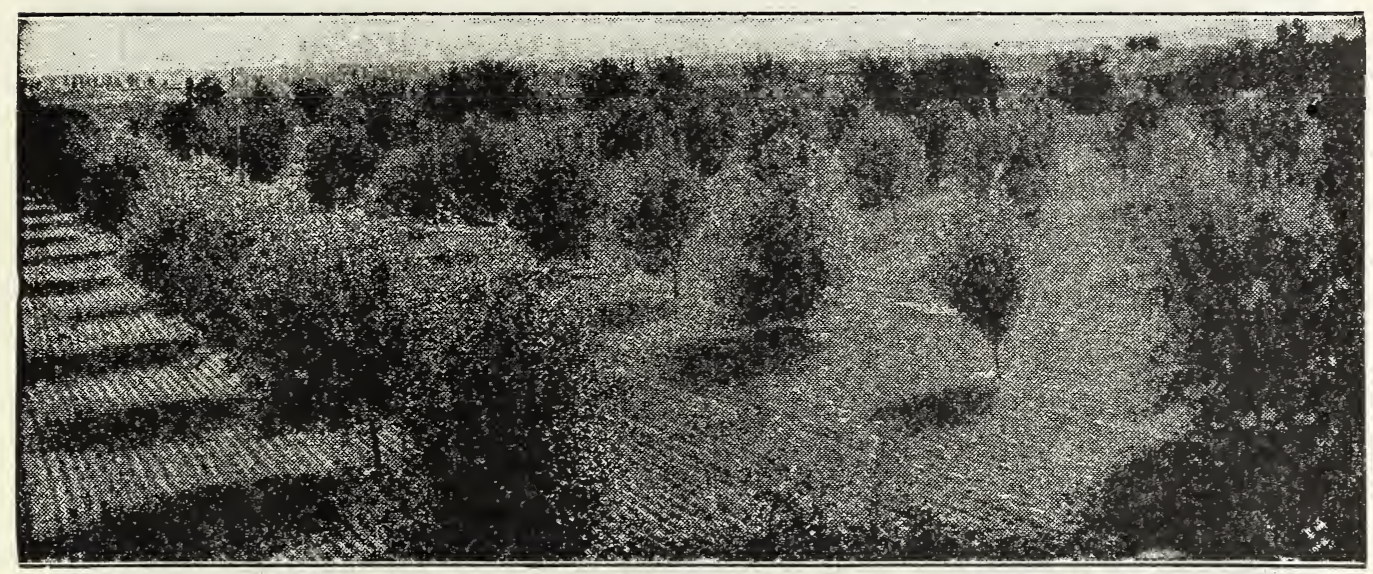

You can grow an orchard like this if you plant our trees

\section{ONE-YEAR-OLD}

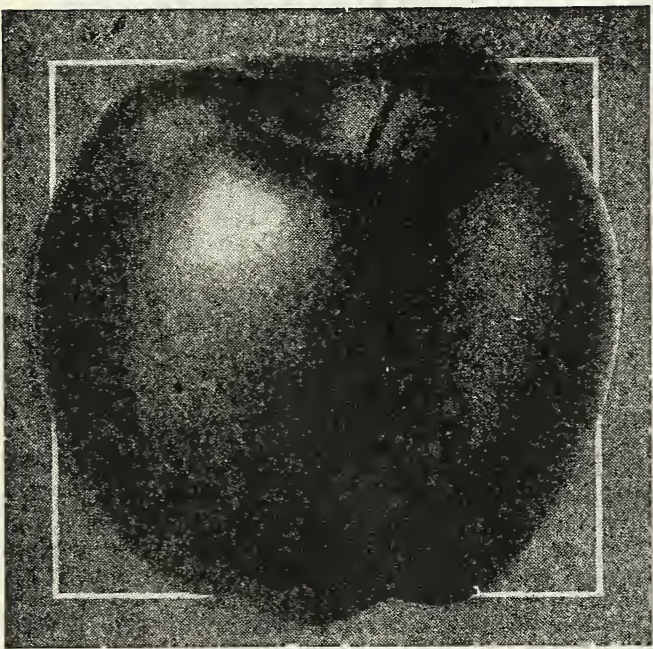

Jonathan

$\mathbf{P}$

RACTICALLY all Western planters and a great many Eastern planters now prefer young trees, because the orchard better than ing from the nursery to the orchard better than must be grown just right, else it will not come into bearing as soon. Many nurserymen lack the soil and experience to grow good one-yearold trees, and for that reason offer two and three-year-old trees. The secret of handling a successful orchard is to buy virile young trees, selecting the most vigorous. The one-year-old tree is a sturdy whip with few, if any branches. Prof. F. C. Sears, who is the professor of pomology, Massachusetts Agricultural College, says in his recent book, "Productive Orcharding": "Personally the writer is rather strongly in favor of the one-year tree for the following reasons: It costs less. Only thrifty trees are salable at one year. The tree can be headed at any desired height. It will stand transplanting better."

We strongly recommend one-year-old apple trees for orchard and home planting. The roots are not damaged by digging and resetting as they are on the older trees. They will take hold

\section{APPLE TREES}

and become established in a new location much sooner than the older trees. They will make thriftier trees and can be trained to any desired shape and height. The men who make a success with commercial orchards select thrifty one-year apple trees, knowing that they will give better results in the development of a bearing orchard.

Experienced fruit growers are demanding oneyear trees. With the one-year-old tree they get a better root system, and there is less damage to the roots in transplanting. They can start the tops and train them to the height and shape that they desire. The one-year trees make a more vigorous growth and are usually more satisfactory in every way than the older trees.

Our one-year-old apple is the best tree to plant. For our yearlings are equal to the threeyear-old trees grown in other soil. We mean simply this: We grow a tree in one year that it would take three years to produce in other soil. This is a strong statement and if it is true the value of our trees should be apparent. Further, our prices are much cheaper than those charged by other nurseries for trees of equal value because we grow them so much faster that we can sell them for less money.

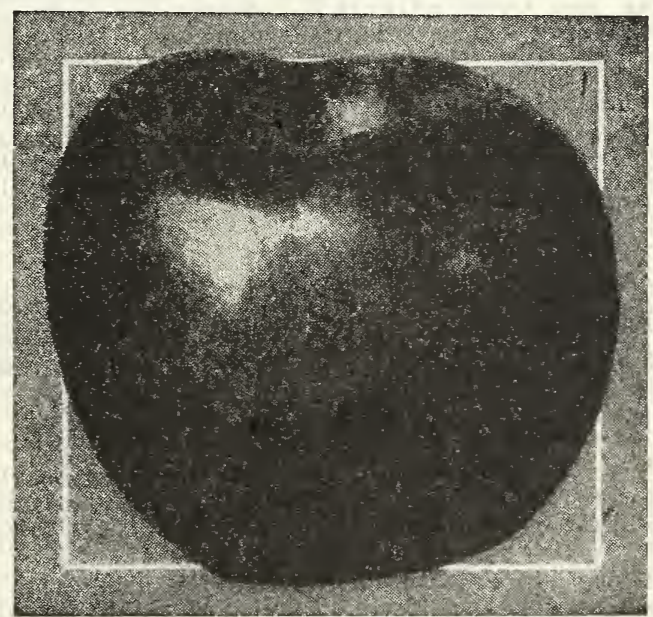

Winesap 


\section{MHARDY TREESAND PLANTS}

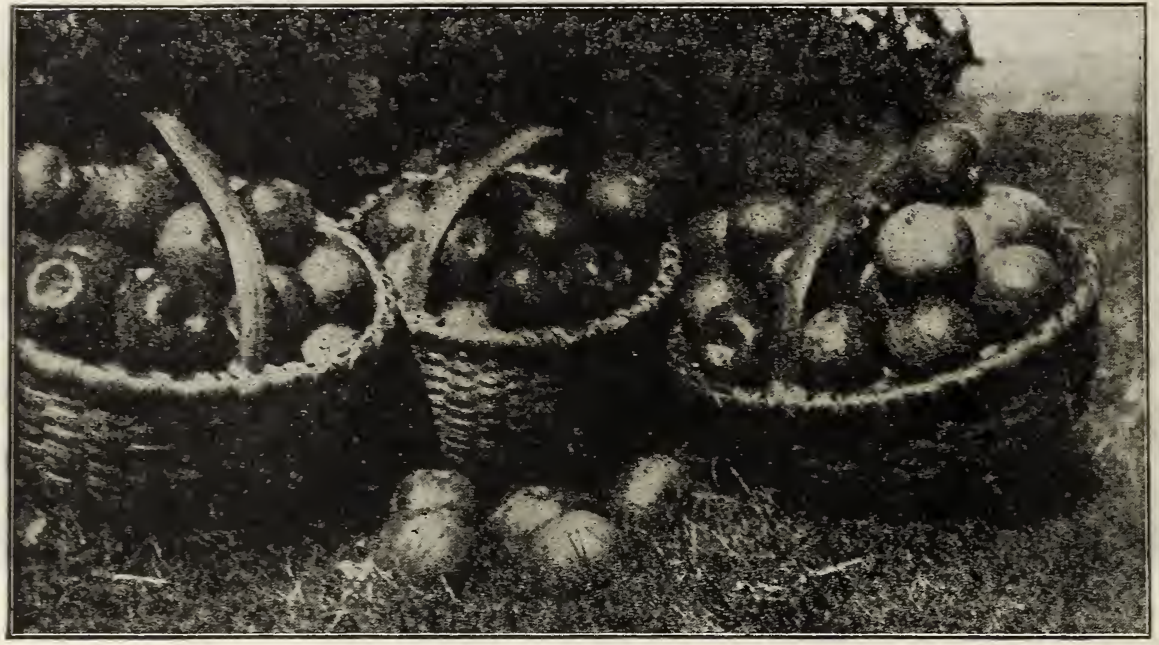

Grow Apples and fill your pockets with money

\section{APPLES!}

APPLES!

\section{APPLES!}

We not only have better soil but we have a longer growing season. Facts about the fertility of Arkansas soil for fruit growing may be had from the United States Department of Agriculture. The bulletins put out by this department are interesting reading and back up every thing we say about climatic and growing conditions for fruit trees in the Ozark region.

Ozark grown apple trees make money for all who plant them. The soil and the climatic conditions where we grow these trees are favorable to the growing of stock that is both hardy and vigorous, with well developed root systems. In short, our Arkansas grown trees are trees that thrive in every section. This season we are growing 200 acres of fine fruit trees. Since we are growers and not merely brokers and ship to you direct at rock bottom prices you can be sure our varieties are true to name for we do not substitute them.

Our trees are growing and thriving and producing fruit in every state in the Union. WVe propagate them from the choicest strain that it is possible to select. The soil around Fayetteville is so admirably adapted to fruit growing that the trees naturally develop very sturdy roots, and every scientific method is used to further this development, which enables the newly transplanted trees to establish themselves quickly and make rapid and continuous growth.

Here are the low prices we are making this year on our high grade Apple Trees, finest in the world. Your money back if not thoroughly satisfied.

\section{Price List}

2 3-ft. Each 30c, 10 for..\$2.00 100 for. $\$ 15.00$

3 4-ft. Each 40c, 10 for.. 2.50100 for. 20.00

4 5-ft. Each 50c, 10 for.. 3.50100 for.. 30.00

\section{Summer and Early Varieties}

Yellow Transparent-One of the best early market apples. Trees medium size, vigorous and hardy, and will bear at two and three years.

Early Harvest-Tree healthy, vigorous and a good bearer. Fruit yellow, with sub-acid flavor, flesh tender and juicy.
Red June-Medium, red; flesh white, tender: good flavor. Abundant bearer.

Red Astrachan-Tree vigorous, hardy and good bearer. Fruit large and handsome, crimson, rather acid, and a good cooker.

Malden Blush-A fine variety for home use and market. Yellow with red cheek, large, tender and very juicy. Tree medium size, vigorous and hardy.

Liveland Raspberry-Good commercial variety and one of the best early market apples. Tree hardy, vigorous and long lived. Bears young. Fruit medium size, clear waxen white, striped with crimson. Flesh crisp, Juicy and almost sweet.

\section{Autumn or Medium Varieties}

Wealthy-One of the most desirable of the fall varieties. Fruit medium size, almost solid red color: flesh white, subacid and very good. Splendid keeper. Treo very hardy and a vigorous unright grower.

Duchess-Tree hardy, nne grower and abundant bearer. Fruit large, yellow, tender and juicy. Good commercial variety.

Rome Beauty-Large size, with red stripes; tender juicy and good flavor. A good grower, bears heavily every year. Very desirable for either home or market.

Mammoth Plppln-Large green sub-acid; quality best.

\section{Winter or Late Varieties}

Arkansas Black-Dark red, almost black, good keeper. Tree comes into bearing young.

Black Ben Davis-An apple of the Ben Davis type; large red apple; a fine market apple. Tree hardy and vigorous.

Ben Davis-Large, round, bright deep red striped; flesh, white sub-acid, firm and jucy. Tree vigorous, upright and productive.

Champion-Rright red, medium size, good keeper and good bearer. Tree hardy and vigorous. A fine commercial variety.

Delicious-See description on inside cover.

Grimes Golden-Large golden yellow, juicy, tender and sprightly sub-acid. Very good. Vigorous grower.

ingram-Medium size, yellow sprinkled with bright carmine stripes; flesh, juicy and of excel- 


\section{G A ARANSAS Nursery COMPANYY}

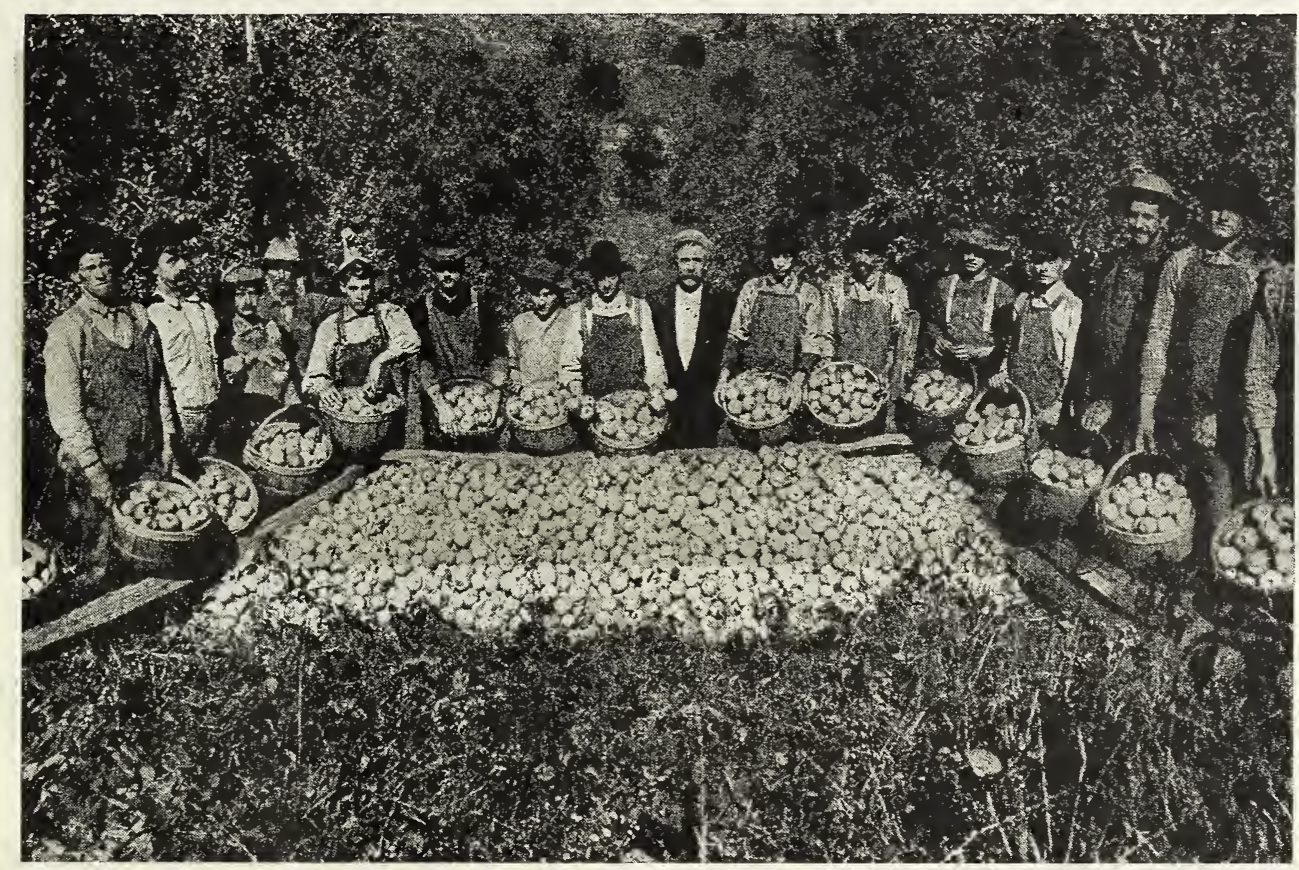

Our Apple Trees bear fruit.

\section{APPLES! \\ APPLES! \\ APPLES!}

\section{Winter Varieties - Continued}

Jonathan-A beautiful red apple, highly flavored and of excellent quality, being tender, juicy, and rich. A splendid family apple and one of the best commercial varieties. Tree long lived, productive and an early bearer.

King David-Medium size early winter apple; very dark rich red; flesh is firm, juicy and of good quality; a good shipper. Tree is very hardy, vigorous grower, comes into bearing very young.

Mammoth Black Twig-Fruit large, round, dark red, almost black when fully matured. Tree a vigorous grower and abundant bearer.

Stayman Winesap-Tree hardy, vigorous and spreading and an abundant bearer. Fruit dark, rich red, lightly striped. Flesh is flrm, crisp and juicy. The Stayman is an apple that is not only desirable in the home orchard, but is one of the most proftable when grown for commercial purposes.

Winesap-Medium size, smooth dark red; flesh yellow, crisp, firm, with a rich, high flavor. Fine in quality and a good keeper. Tree a strong grower, root-growth exceptionally strong; an early and productive bearer.

\section{Crab Apples}

IMPROVED VARIETIES.

Whitney-One of the largest and handsomest Crabs. Flesh firm, juicy and rich. A great bearer and extra hardy. Tree a vigorous and beautiful grower. Excellent for cider and cooking. Season early.

Transcendent-Tree immensely productive, bearing after the second year. Excellent for sauce or pies, either green or dried, and unsurpassed for cider. Flesh yellow and crisp,

with an agreeable flavor. Season medium.
Hyslop-A handsome Crab of excellent quality and unsurpassed for general purposes. Flesh yellow, with a sub-acid, pleasant flavor. Tree highly ornamental. Season late.

Arkansas Seedling Crab-We recommend this variety for its hardiness. The fruit is of good size and very desirable for preserving.

Price of first-class trees, 30c each; $\$ 3.00$ per dozen; $\$ 20.00$ per 100 .

Gatesville, Texas, Jan. 20, 1921.

1 received the trees and vines in fine shape. I heartily thank you for the trees you sent the children.. I have sent you an. other order which I hope you have received by now and expect to order more soon.

\section{A. THOMPSON.}

Mammoth Springs, Ark., Nov. 15, 1921. Received the goods you sent some time ago. It arrived in fine condition.

MRS. T. E. APPLEMAN.

Cove, Arkansas, Dec. 20, 1920.

1 received 50 Apple Trees from you three years ago and they were extra fine. I will need a few more Peach, Plum, Cherry, and perhaps others for spring. Please send me your spring catalog when ready. WALTER ELLIOTT.

Liberal, Kansas, Dec. 12, 1920.

About two years ago I answered your ad in a paper and got 10 apple trees. Wish to tell you that they are growing nicely and am thinking of planting out more trees and shrubs. So would like to have a copy of your latest catalog.

$$
\begin{aligned}
& \text { Yours for success, } \\
& \text { O. A. MINTON. }
\end{aligned}
$$

Drumondville, Wyo., March 31, 1921. Gentlemen:

I received the Strawberry Plants in good condition. Am well pleased with them. MRS. BELLE MAHAFFEY. 


\section{HARDY TREESAND PLANTS}

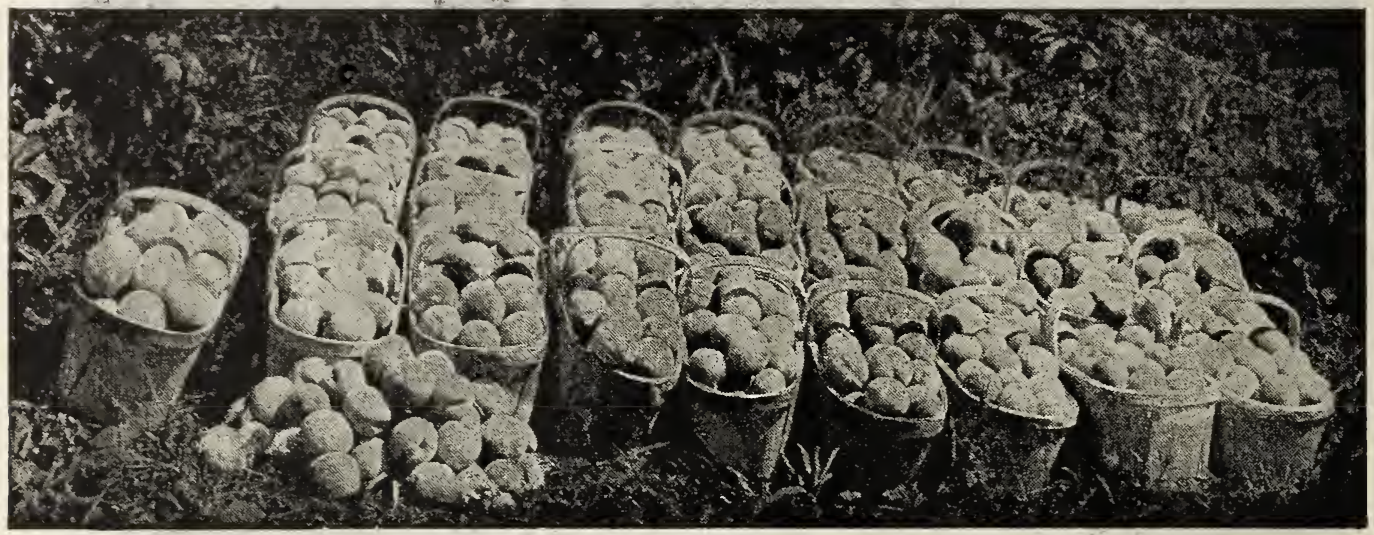

PEACHES

\section{PRICE LIST}

2 to $3 \mathrm{ft}, 25 \mathrm{c}$ each; 10 for $\$ 2.00 ; 100$ for $\$ 15.00$

3 to $4 \mathrm{ft}$., $30 \mathrm{c}$ each; 10 for $2.50 ; 100$ for 20.00

4 to $5 \mathrm{ft}$., $35 \mathrm{c}$ each; 10 for $4.50 ; 100$ for 25.00

Special price on Elberta in large lots for conmercial planting.

\section{First Ripening}

Mayflower-Earliest peach known, semi-cling, medium size, color bright red; ripens well to the seed. Young and prolific bearer. Tree an upright good grower.

Red Bird-A fine early Peach; bright glowing red. A good shipper. Flesh juicy, firm and most delicious peach flavor imaginable. Tree hardy and vigorous.

Alexander-Medium greenish white, nearly covered with rich red, melting, juicy, sweet.

\section{Second Ripening}

Carman-Large creamy white or pale yellow with deep blush; flesh tender, fine flavor and quite juicy very hardy and productive. Good shipper.

Early Crawford-A large yellow Peach of splendid quality; strong grower and prolific fruiter.

Greensboro--The largest and most beautifully colored of all early Peaches: prolific and of excellent quality; juicy; freestone but adheres slightly.

\section{Third Ripening}

Belle of Georgla-Very large, white Peach with red cheek; flesh white, firm, and excellent flavor. Tree rapid grower and very productive.

Champlon-Fruit large, beautiful in appearance; flavor delicious. Skin creamy white with red cheek; valuable for commercial orchards very hardy and productive.

Early Elberta-Large freestone Peach, red cheek, yellow fleshed, with distinctive yellow peach flavor and odor. It is a heavy and regular cropper.

\section{Fourth Ripening}

Elberta-The most popular Peach grown. Large, yellow with red cheek; flesh yellow, firm, juicy and of high quality. Exceedingly prolific, sure bearer and hardy.

J. H. Hale-Large round, flrm; white with red cheek; flesh white, juicy, and very good. Hardy and very productive.
Triumph-Large yellow freestone, nearly covered with red; flesh yellow, juicy with a very agreeable flavor; strong, vigorous, and very productive.

\section{Fifth Ripening}

Chinese Cling-Hardy and productive; flesh white, red at the stone, very juicy, melting with a rich, excellent flavor. Clingstone.

Crawford Late-Superb yellow Peach of large size and excellent quality; great bearer. One of the finest late varieties.

Indian-Large, dark claret, very downy, flesh deep red. Much esteemed for pickling and preserving.

\section{Sixth Ripening}

Heath .Cllng-Very. large. oblong, creamy white, with a faint blush; flesh greenish white, tender, and juicy. One of the finest for canning purposes. Tree a good grower and excellent bearer.

Lemon cling-Large oblong, yellow with a red cheek; flesh yellow, firm, with a rich subacid flavor.

Stinson October-Large oval, creamy white, with fine blush; flesh white and rich.

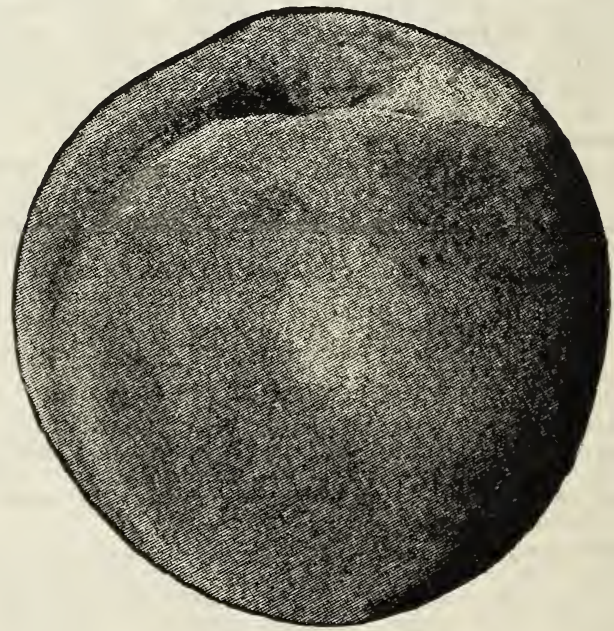

J. H. Hale 


\section{G ARANSAS Nursery COMPANTY

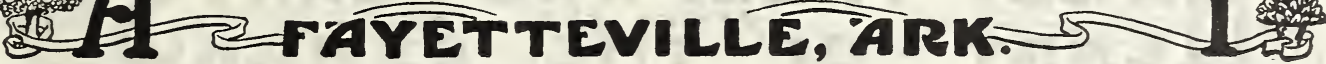

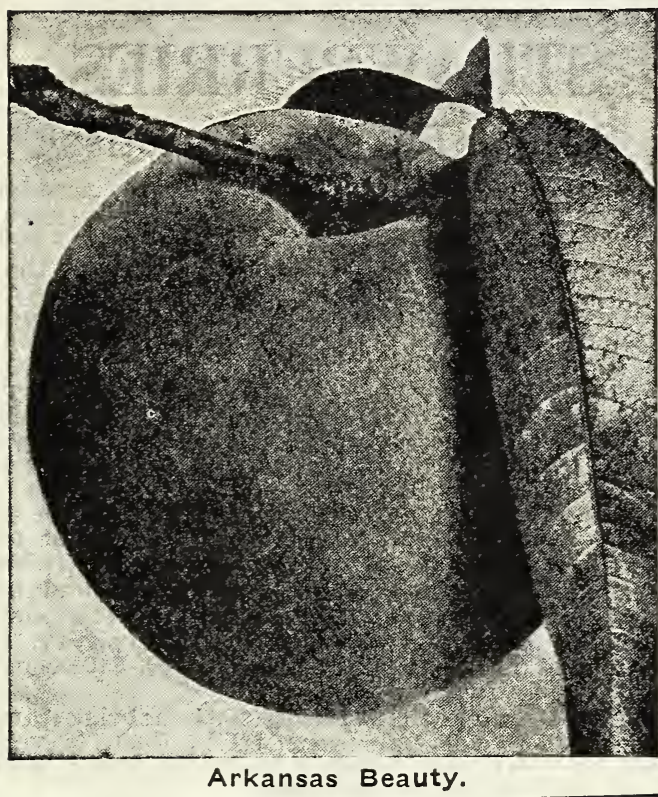

Cherokee, Kansas, April 31, 1920. Arkansas Nursery Co., Dear Sir:

I have received my strawberry plants all O. K. They were alright and fresh.
R. 1, Box 35 .
A. TONNELIER.

\section{SEEDLING PEACHES}

Plant a few Seedling Peaches for home use There is a flavor and quality about Seedling Peaches that appeals to many people. The trees are thrifty and hardy and they will sometimes bear when the budded trees fail. Our trees come from stock that produces large crops of fruit. They are grown in our Mountain Nursery, and are strong, well-rooted trees that will please you.

Common Seedling Peaches-Extra fine trees. Plant some of these trees.

There should be more good varieties of seedlings planted, for there are seasons when there is not a crop of budded varieties, and the seedling trees produce a good crop.

Prlce 30c each, 10 for $\$ 2.50 ; 100$ for $\$ 15.00$.

\section{Dear SIrs:}

Gravett, Ark., March 1, 1920.

Received the Apple Trees and Strawberry Plants In good condition. Thanking you for prompt servlce, I remaln,

Yours respectfully, JOSEPH WELLS, R. 4.

Ft. Smlth, Ark., R. 1, Box 81. Marlonville, Mo., March 19, 1920. Gentlemen:

The plants ordered from you came on time and in good shape. Thanks for the prompt way you do business.

Yours truly,

L. S. BEECHER.

\section{Choice of Native Varieties of Arkansas Peaches}

\section{Price of First-Class One-Year Trees 50c Each.}

Arkansas Beauty-Ripens ten days later than Crawford Early, free stone, white with red blush, splendid bearer, small seed, good size. A very valuable peach.

Arkansas Traveler-Ripens early, juicy, is sweet, nearly free, good bearer.

Madison County Mammoth-Very large, season August, white with red blush, extremely hardy and productive. Cling stone.

White English-A large white cling stone peach, juicy and sweet, fine for canning.

Arkansas Indian Cling-Solid red, good size, attractive.

Anderson, Texas, April 11, 1921.

I received the Strawberry Plants in good condition. I must say that I am more than pleased with them. I set them out exactly as you told me to, and they are progressing nicely. I am expecting to send you a big order another year. Thanking you for your promptness.

Respectfully,

J'AS. M'GILL.

Salina, Kansas, March 28, 1921.

The Strawberry Plants received in good condition. We are well pleased with them. Many thanks.

MRS. J. M. DAVIS.

Dear SIrs:

Marshfleld, Mo., March 6, 1920

I recelved the Pieplant all O. K. Thanking you very much, I remaln, As ever,

MRS. OLIVER DITTRICK.

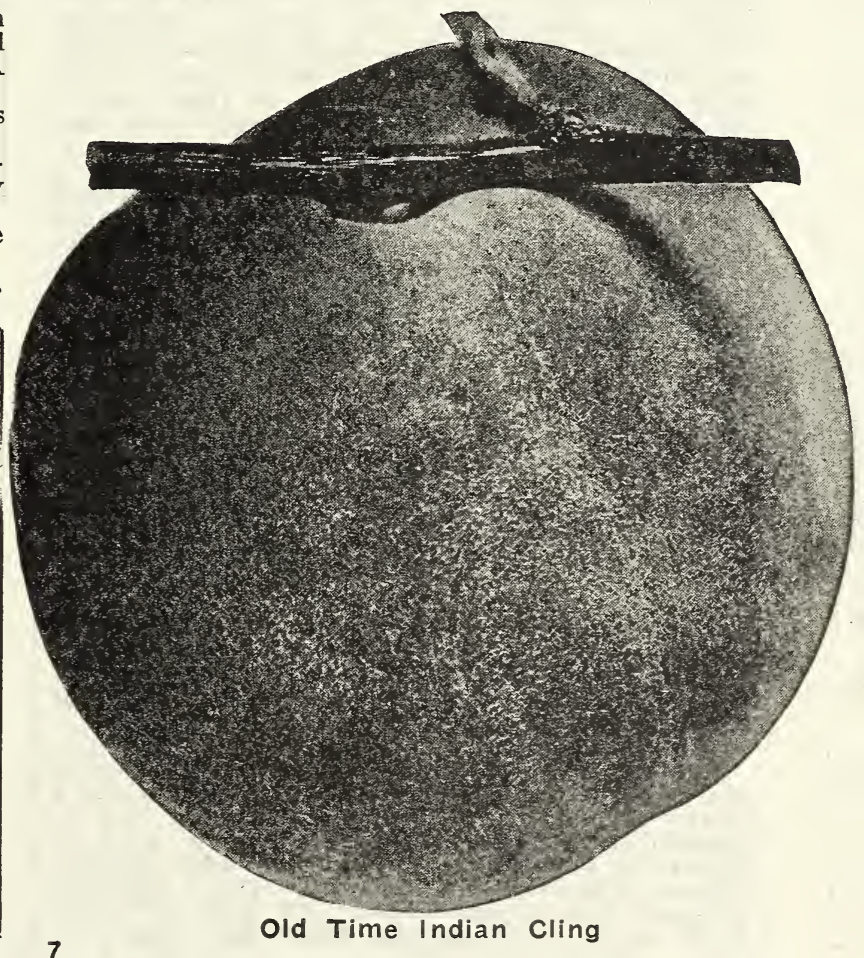




\section{MHARDY TREES AND PLANTSG}

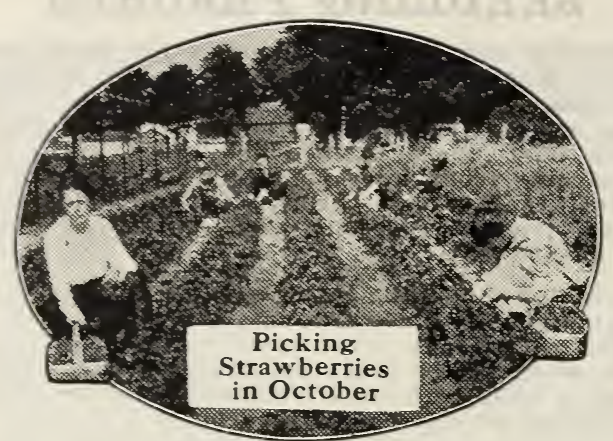

\section{Everbearing Strawberries}

The two essential requirements for the success of the culture of the ever-bearer are a soil of exceptional fertility, and constant cultivation throughout the entire growing season. Heretofore we have listed both the PROGRESSIVE and SUPERB varieties of the Everbearers but the demand for the latter have diminished so that we feel that our trade prefers the PROGRESSIVE.

Other varieties will bear a few berries the first autumn. But one must wait until the following year for a full crop, and then if the plants are allowed to bear the June crop, as they will unless disbudded, they are so exhausted that the fall crop is much smaller than that produced by the PROGRESSIVES the first season. For this reason, PROGRESSIVES grown for the one season's crop alone, setting a new bed each year, will pay better than to grow the other varieties that require a year's growth before producing a full crop. WWe find that the PROGRESSIVE is the best shipper, holding up for long distance shipping equal to almost any other June variety. In flavor and quality it is equal to, if not surpassing, any other Ever-bearer we have tested. We urge everyone to plant some of this variety as we know you will be pleased with the results obtained.

The idea of having fresh, well flavored strawberries from June to November would have been ridiculed a few years ago. But the Everbearing Strawberry is here in actual fact. It has been tested, tried and proven. It has made good in both commercial and home garden plantings in widely varying parts of the country. The first crop i $\mathrm{s}$ borne early in the season at the same time as the standard or June bearing varieties, then there is a continuation of blooming, producing ripe fruit throughout the summer, if conditions are favorable. Following this is another blooming period in the late summer and a large crop follows until severe frosts come. We recommend that you plant a few of one or both of the tested varieties described below.

Progressive (S)-Said to be the best of the fall bearing varieties: immense plant maker. Fruit medium size, high colored, red to the core; if picked before too ripe will ship well. $\$ 1.00$ for $25, \$ 2.00$ per $100, \$ 15.00$ per 1,000 .

Superb (Perfect Flower)-Plants are strong and stand the winter well after producing a heavy crop of fruit from about August 15th to November, according to season. The fruit of Superb is very large, round, rich, dark colored, glossy, attractive and smooth. Each berry is of good shape and ripens all over at once. $\$ 1.00$ for $25, \$ 3.00$ per $100, \$ 20.00$ per 1,000 .

\section{STRAWBERRIES}

\section{Spring Bearing Varieties}

Klondyke-The hardiest and most popular strawberry known; very productive; a great market variety. $\$ 1.00$ per $100, \$ 7.50$ per 1,000 .

Lady Thompson-A well-known variety that is quite popular, running medium to large size. A splendid market berry because it is a good shipper and keeps well in storage. $\$ 1.50$ per $100 ; \$ 10.00$ per 1,000 .

Senator Dunlap-One of the best for preserving and canning, making a rich red syrup and the berry retains its bright red color. The plant is one of the hardiest and most vigorous. $\$ 1.50$ per $100, \$ 10.00$ per 1,000

Mitchell's Early-An excellent flavored berry that is very productive and one of the best for home planting. 82.00 per $100, \$ 15.00$ Der 1.000 .

Aroma-The most profitable and dependable strawberries grown. The flavor is deliciously aromatic and the flesh is firm and velvety, of a smooth solid texture. $\$ 1.50$ per $100, \$ 10.00$ per 1,000

Gandy-An excellent berry with a brisk tartness that is very pleasant. The flesh is very firm so that the berry stands shipping well. $\$ 2.00$ per $100, \$ 15.00$ per 1,000 .

Every farmer can give some acreage to Strawberries with profit. We cannot predict the future but to us it seems wise that everyone devote as much acreage to small fruits as his land permits, for it will pay him.

Prices paid for strawberries, raspberries, grapes and other small fruits undoubtedly will remain high. As high as $\$ 500.00$ to $\$ 750.00$ has been brought from an acre by fruit growers in a single season. What other crop would pay any such big returns?

This year we have grown a large acreage of strawberries - and have millions of as fine plants as you ever laid your eyes on. Altogether we feel that we have a stock of plants such as we never before offered the public.

Dear Sirs:

Anadarko, Okla., Dec. 22, 1920.

1 received the plants you sent me and they are O.K. Many thanks for them.

F. T. WILLIAMS.

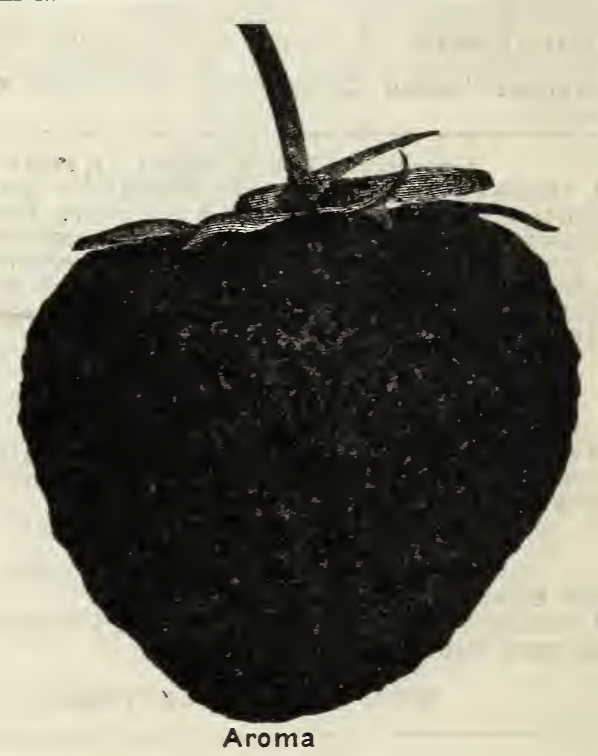




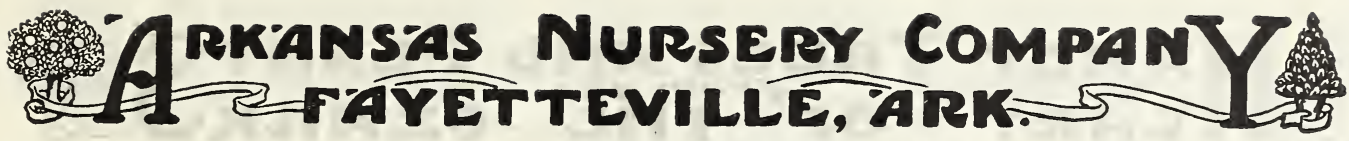

\section{QUINCE}

Orange - Large, delicate flavor. Bears abundantly while young. Flesh cooks as tender as an apple and without hard spots and cores.

Price of Qulnce Trees, $\$ 1.00$ each.

\section{PLUMS}

Plums are easy to grow anywhere. Yet they are not grown on many farms. There is a healthy demand for the fruit. The trees produce abundantly. Everyone likes plums. They are good shippers. All markets can be greatly extended and developed.

Price of Plum Trees, 1-yr. 50c, 2-yr. 75c.

Abundance-An early pinkish-red plum. Ripens in midseason. Thrives everywhere. A regular and heavy bearer.

Burbank-Adapted to any soil and climate any other plum is grown. A profitable commercial plum. Requires little care. Ripens in mid-season.

Red June-An early market plum of large size, with deep vermilion red color, with light lemon yellow flesh, very firm, slightly sub-acid. Free from rot. Ripens in early August.

Wickson-A large, long, heart-shaped, deepmaroon red cling plum, with small pit. Tree an upright, vigorous grower. Excellent keeper and shipper. Planted largely for market. Early September.

Lombard-Medium, round, oval, violet-red; juicy, pleasant and good; adheres to the stone. Tree vigorous and productive. A valuable market variety; one of the most hardy and popular. July.

Shiro-Medium sized, yellow and very sweet. The best quality of any of the Japan plums. Recommended highly for garden planting.

WIId Goose-Deep red, very sweet and Juicy. Tree a hardy and vigorous grower and an abundant bearer.

Moore's Arctic-Purplish, black skin, with greenish yellow flesh. Juicy, sweet and pleasant and medium size.

Mariana-An unusually strong, rapid grower. Fruit larger than the wild goose, round and of a peculiar light red color.

Gold Beauty-A large variety in a rich yellow. Flesh is very firm and sweet. A variety that always is in big demand.

\section{PRUNES}

Itallan Prune-Large, dark, purple, flesh greenish yellow. Price $\$ 1.00$ each.

French Prune (Fellenberg)-A fine late plum. Fruit large, handsome, of oval shape and purple color. Flesh thick, greenish yellow, juicy and delicious, parts freely from stone. Excellent for drying and preserving. Very productive. Extensively used in Oregon and Washington for drying purposes. Ripens in September. Price $\$ 1.00$ each.

Pollard, Ark., March 4, 1921.

I received my trees and grape vines. They were all in good condition and I thank you so much for these trees and vines, and also the premlum peach tree you sent.

AMOS E. BOND.

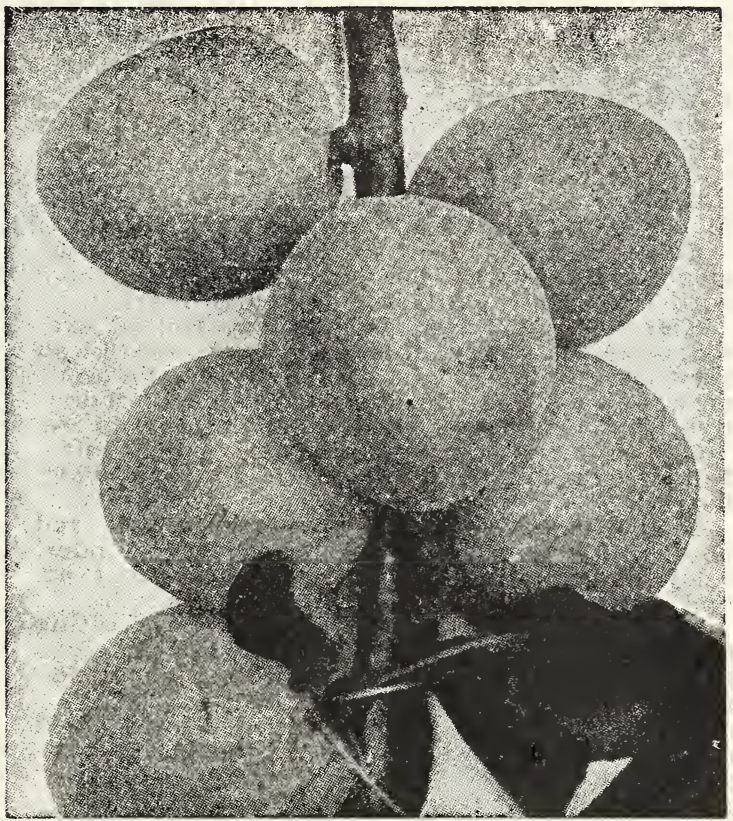

New White Nectarlne-Try Them

German Prune-A valuable plum of fair quality for dessert, but most esteemed for drying and preserving. Large, long-oval, purple with a thick blue bloom, flesh firm, sweet and pleasant, separating from the stone. Moderate to vigorous in growth. September. Price, 50c.

\section{THE NECTARINE}

NHERE is a mistaken idea that the Nectarine is a cross between the Peach and something else, while it is really nothing more or less than a smooth-skinned Peach. The trees bear fully as well as the Peach, and for canning, drying, and shipping it has so many points in its favor it is difficult indeed to comprehend why planters have not engaged in Nectarine culture more extensively than they have. Prof. Bailey, in Cyclopedia of American Horticulture, on page 1064 says: "Nectarines thrive wherever Peaches do." As the Nectarine has identically the same habit as the Peach, the cultural directions are the same.

Red Roman-This variety is particularly recommended for home planting. The fruit is very firm and keeps as well as a Peach. It has a delicious flavor, being rich in sugar, tender and juicy. Price $50 \mathrm{c}$ each.

New White-This is nearly round with tender white flesh, having a rich vinous flavor, and a small stone. Price 50c each.

Warrenville, III., Oct. 27, 1920.

The Strawberry Plants came in good shape and they did well on our sandy soil. Wishing you much success and thanking you for your new catalog, we are,

R. 2, BOX 64. W. G. HOWARD \& SONS.

Dayton, Ohio, Oct. 27, 1920.

Recelved my fruit trees yesterday. They arrived in good condition and $I$ am well pleased with them. Thanking you, I remain, R. 6, Box 78 . 


\section{算}

\section{PEARS}

Price, 2 to $3 \mathrm{ft} ., 40 \mathrm{c}$; 3 to $4 \mathrm{ft} ., 60 \mathrm{c} ; 4$ to $5 \mathrm{ft} ., 75 \mathrm{c}$. Anjou-Large, greenish, shaded with russet crimson. Flesh is highly flavored and rich. Keeps well until winter holidays.

Bartlett-Large size, buttery, very juicy and highly flavored. Bears early and abundantly.

Early Harvest-Fruit medium to large. Rich golden yellow, with her cheek, thickly covered with gray dots. Valuable for early market.

Klefer-Fruit large, rich yellow, tinged with red; somewhat rusty and very handsome. Flesh very white, buttery and juicy. Tree a vigorous grower, early and regular bearer. Very productive, and commands the highest market price.

Garber-Fruit nearly round, large and Juicy. Noted for vigor, freedom from blight, and heavy bearing.

Seckle-Small size, yellowish, with a red cheek. Flesh whitish buttery, very tender, juicy and melting. The common sugar pear, and a very prolific bearer.

Duchess-A dependable cropper, often fruiting the first season. Fruit large, frequently weighing a pound. A profitable market pear. Ready for use in October and November.

Clapp's Favorite-A beautiful fruit of good quality. Tree is an upright and vigorous grower and bears heavy crops of large, juicy pears, with a very agreeable flavor.

Flemish Beauty-Large size, yellow when ripe, with patches of brownish red; rich, sugary flavor. Tree is first-class in hardiness, productiveness and early bearing.

Wilder-Medium small, yellow, with dark red cheek, sweet and good for dessert. Tree very attractive, of vigorous and symmetrical growth.

Vermont Beauty-Medium, roundish, yellow, with carmine cheek. Flesh exceedingly fine, sweet and juicy;: a splendid table pear. Tree makes strong, healthy growth and bears early.

\section{APRICOTS}

THE SEEDLING RUSSIAN APRICOT

A most delicious fruit of the plum species. Is of a distinct flavor and one of the best and most profitable market fruits. The tree bears very young and most profusely. Ripening, as it does between the cherry and peach, the apricot is the most welcome fruit. . The tree is slender in form, has beautiful dark green foliage, pretty pink..blossoms, and will give very satisfactory results as an ornamental tree in garden or house lot. You will find the Russian Apricot

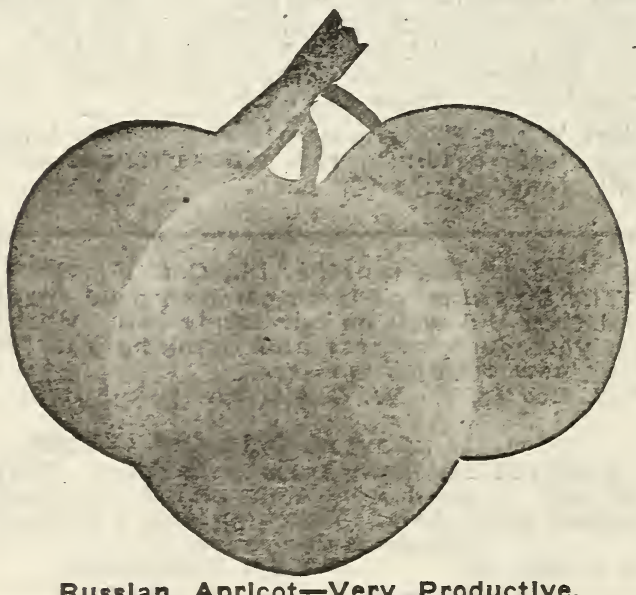

Russlan Aprlcot-Very Productive.

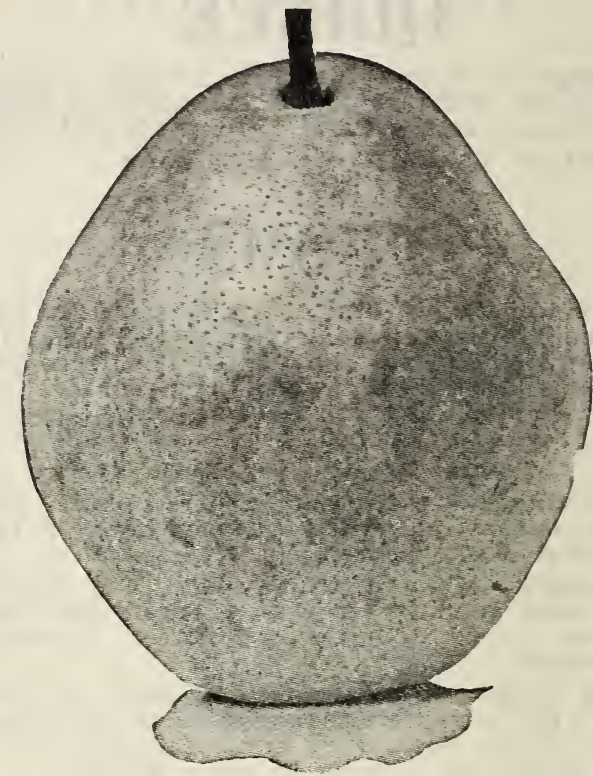

Duchess-Fine for eating and canning. very hardy. It will pay you to plant a few apricots about the place for home use. Price 2 to 3 feet, $40 \mathrm{c}, 3$ to 4 feet $50 \mathrm{c}$.

Alexander-An immense bearer. Fruit yellow, flecked with red. Very beautiful. Price $75 \mathrm{c}$ each.

Early Golden-Fruit beautiful bright yellow, large size, prolific and hardy; tree upright, strong grower. Thrives on any soil. Prlce $\$ 1.00$ each.

Moorpark-Large orange, brownish red to the sun; flesh firm, bright orange; parts freely from the stone; juicy, with a rich and luscious flavor. Price $75 \mathrm{c}$ each.

Royal-A fine large French variety. It is quite high flavored and ripens a week or ten days earlier than the Moorpark; flesh pale orange, firm and juicy, with a rich flavor. Price $75 \mathrm{c}$ each.

\section{CHERRY TREES}

Prices, 34 -ft. $80 \mathrm{c}$ each, 10 for.........\$7.50 Prices, 23 -ft. 50c each, 10 for................ 4.00 Black Tartarian-Very large; purplish black; half tender; mild and pleasant. A remarkably erect and beautiful grower, and an immense bearer. Last of June and beginning of July.

Gov, Wood-Clear light red, tender and de-

licious. Hangs well on the tree End of June.

Early Richmond-An early red, acid cherry very valuable for cooking early in the season. Ripens through June. A free grower, hardy, healthy, and very productive.

May Duke-An old, well known, excellent variety; large; dark red; juicy, sub-acid, rich Middle of June.

Large Montmorency-A beautiful, large red, acid cherry; larger and finer than Early Richmond, and fully ten days later. Being extraordinarily prolific and very hardy, it can be recommended as a variety of great value. Valuable for canning and preserving. A free grower.

Morello English-Large; dark red, nearly black; tender, juicy, acid, rich. Dwarf and slender. August.

Seedling Sweet Cherry-This cherry greatly resembles other sweet cherries in its growth. Very hardy and a prolific bearer. Very juicy and sweet. You will be delighted with this 


\section{ARKANSAS NURSERY COMPANT GRAPES}

NO MATTER how small the space for from four to six grape vines, which will bear an abundance of luscious fruit which cannot be surpassed. They can be trained over the garden fence, over the veranda, not only furnishing fruit, but making a vine that is beautiful and at the same time furnishing shade. Probably the best way to grow grapes, however, is in rows, planting the vines from six to eight feet apart each way and training on trellis. Work the ground deep and well for grape vines, planting a little deeper than they stood in the nursery rows. Keep pruned severely for the first two or three years, allowing the vines to form four or five main stems, when later growth will suggest individual pruning. We again say plant the grape, for both home and market, for no fruit will come nearer pleasing all tastes and adapting itself to all soils.

Brighton-Bunch large, shouldered; berries medium large, dark red, tender; rich sweet, and of best quality. Vine vigorous and hardy. Price $30 \mathrm{c}$ each, 10 for $\$ 2.50$.

Campbell Early-Black with purple bloom: bunch and berries large. Juicy with rich sweet flavor; almost seedless; hardy and vigorous growth, and very productive.

See special offer on front cover. Price $30 \mathrm{c}$ each, 10 for $\$ 2.50$.

Concord - The most popular grape in America. They grow in full clusters of large berries, with a thin skin; flesh tender, sweet and juicy. Vine a strong grower and very hardy. Price $25 \mathrm{c}$ each, 10 for $\$ 2.00,100$ for $\$ 15.00,1,000$ for $\$ 100.00$.

Cynthlana-Absorbs from the soil more iron than any other plant grown, and grape juice made from this grape is famous for family physician's and hospital use and medical purposes. Price $50 \mathrm{c}$ each, 10 for $\$ 4.00,100$ for $\$ 30.00$.

Delaware-One of the finest table grapes. Bunches not large; compact and well shouldered. Berries rather small, juicy and sweet, without any hard pulp. Price $30 \mathrm{c}$ each, 10 for $\$ 2.50,100$ for $\$ 20.00$.

Improved Delaware-Much larger and better grape than the Delaware. The vine is a hardy, vigorous grower. A very fine delicious table and market grape. Price 40c each, 10 for $\$ 3.00$, 100 for $\$ 25.00$.

Ives Seedling-Black. Bunch long, medium to large, compact; berries medium; skin thick and tough; flesh sweet. It is a good market variety and is highly esteemed for red wine. vine hardy, very vigorous and healthy. A good shipper. Ripens medium late. Price 40c each, 10 for $\$ 3.00,100$ for $\$ 25.00$.

Moore Early-An extra large grape of extraordinary fine sweet flavor. Excellent for home use and one of the hardiest for the far north, ripening about two weeks ahead of the Concord. Berries of large size; succeeds everywhere. A fine market grape. Price 35c each, 10 for $\$ 3.00,100$ for $\$ 25.00$.

Nlagara-This is one of the very best white srapes in existence. Berries large, light green-

ish yellow; very fine for table use; very prolific, hardy and of fine flavor. Fruit keeps well. if properly handled. Price $35 \mathrm{c}$ each, 10 for $\$ 3.00$, 100 for $\$ 25.00$.

Scuppernong-This variety is purely Southern, and is of no value to the Northern or Western states. The vine is free from all diseases; fruit never decays. Plant twenty to thirty feet apart in rows. Train on an arbor or trellis and never trim. The product is very large and cultivation reduced to simple form. Price $50 \mathrm{c}$ each.

Worden-A splendid grape of the Concord type, larger, better quality and earlier. Vines vigorous, hardy and productive. A valuable market sort. Price $35 \mathrm{c}$ each, 10 for $\$ 3.00,100$ for $\$ 25.00$.

Watonga, Okla., April 8, 1921.

We take this opportunity to say we ap. preciate very much the premium peach sent with plants ordered. It is growing fine. Yours very truly,

Box 81. JOHN HERIFORD. 


\section{MARDY TREESAND PLANTS RASPBERRIES}

OMING immediately after Strawberries, when there is a dearth of other fresh fruit, Raspberries are equally desirable for planting in the garden for home use añd in the fleld for market. They are easily cultivated. Beds seldom require renewing. Their season of ripenIng is long. The fruit bears transportation well, and aside fro mits demand for immediate consumption, it brings highly remunerative prices for drying and canning.

\section{Red Varieties}

Brandywine-Large; bright red; very fine. Valuable for market on account of its fine shipping qualities. 10 for $75 \mathrm{c}$, 100 for $\$ 5.00$.

Turner - A beautiful red berry of fine size and excellent quality. One of the hardiest and most productive varieties known. 10 for $75 \mathrm{c}$, 100 for $\$ 5.00$.

Miller's Red-Vigorous and sturdy; very early; fruit large and profuse, beautiful and brilliant in color. 10 for $75 c, 25$ for $\$ 1.50,100$ for $\$ 5.00$.

King - Large, crimson; firm; flavor very good; abundant and early bearer. 10 for $75 \mathrm{c}, 100$ for $\$ 5.00$.

Louden-Ripens with the earliest and hangs to the last. In productiveness it is beyond any red raspberry known, and is a famous shipping berry. It is as hardy as the Turner and is of superior quality. 10 for $75 c, 25$ for $\$ 1.50,100$ for $\$ 5.00$. Cuthbert-(The Queen of the Market). Large, conical; deep rich crimson; firm, of excellent quality. A vigorour grower, entirely hardy and immensely productive. "I regard it as the best raspberry for general culture." - Charles Downing. 10 for $75 c, 25$ for $\$ 1.50,100$ for $\$ 5.00$.

\section{Immediate Returns}

$\$ 200$ to $\$ 500$ From One Acre. We do not claim that raspberries will make you a fortune without work, but we do claim that you can make good money growing raspberries. Beginning to

bear the next year after planting they bring quick returns. Raspberries grown either alone or in combination with other farm products will pay you handsomely for your labor and prove a profitable investment. You will always find a strong local demand for choice raspberries of both red and black varieties. They will stand shipping fully as well as strawberries, and the city markets are never fully supplied with this delicious berry. Under favorable conditions the raspberry crop will bring a cash return of several hundred dollars per acre. We have reports of $\$ 500.00$ an acre. Of course this was extra good return and could not be expected unless conditions were very favorable. We can assure you, however, that you will find raspberries a profitable crop.

Raspberries ripen at a time when the appetite of the people is demanding fruit, and they will fll in the gap between strawberries and blackberries. Growing on upright bushes they

are easily picked and require less labor for marketing than strawberries do.

\section{BLACK RASPBERRIES}

Black Pearl-This new blackcap was introduced a few years ago from Kansas and it certainly is a winner. The fruit is glossy jetblack, very large, firm and plentiful. It ripens with the very earliest and comes on so fast that its immense crop is gone inside of fifteen days from time the first berries ripen. The canes are healthy, vigorous and hardy, and we regard this as one of the very best varieties in our list; it eertainly is the best very early variety, either for the home garden or for market. You will miss something really good if you fail to include this in your order. 20 for $\$ 1.00,100$ for $\$ 4.00,1,000$ for $\$ 30.00$.

Kansas-A seedling originated at Lawrence, Kansas. Berries very large, jet black and of the very best quality. It stands the tryins climate of Iowa. 20 for $81.00,84.00$ per 100. 


\section{ArKansas Nursery COMPANY A PAGE of SELECTED BERRY PLANTS}

For Home or Commercial Planting

We want our patrons to grow the very best varieties of berries. We are not going to confuse you by offering a long list of varieties. You can make no mistake by planting these varieties.

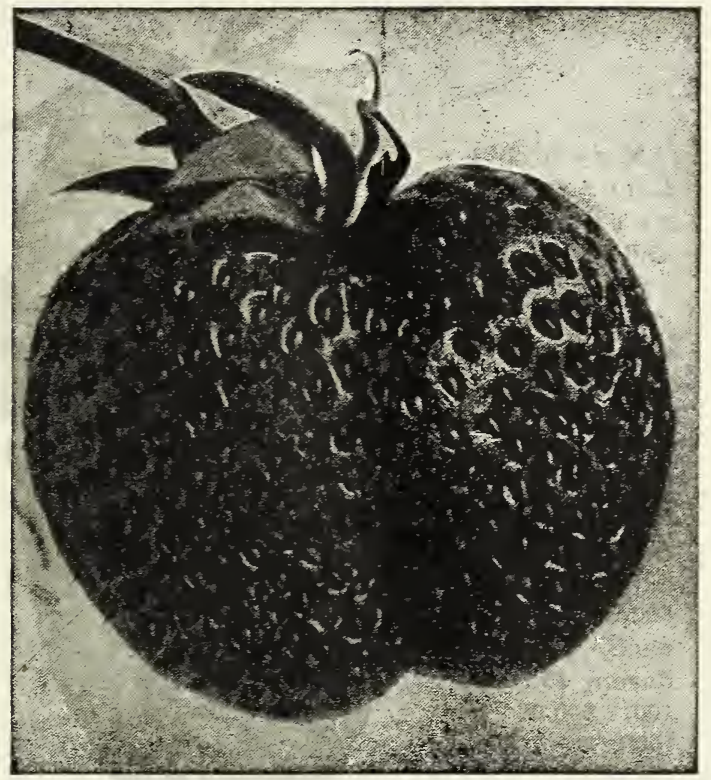

berland is very hardy everywhere. Extra productive, being the heaviest bearing variety in cultivation. Fruit is extra large, jet black, and of superior quality. Ripens medium early. This is the Standard Black Cap Raspberry, being more extensively grown than any other variety. Price 3 for $25 c, 12$ for $85 c, 50$ for $\$ 2.75,100$ for $\$ 5.00$.

\section{Choice Blackberry}

snyder-This popular hardy blackberry is known everywhere and more largely grown than any other because of its extreme hardiness and dependability. Where other varieties often fail by winter killing. Snyder can always be depended on for an abundant crop. It is the blackberry for every fruit grower. It is enormously productive, large, sweet and free from core. Price 2 for 25c, 12 for $\$ 1.00,50$ for $\$ 3.50,100$ for $\$ 6.00$.

\section{Choice Dewberry}

Lucretia-The most largely grown of all the dewberries for home or market. It is a trailing species of blackberry. It is earlier than the earliest blackberry and larger than the largest of them. The trailing canes are hardy everywhere and free from disease. The fruit is superb, large and handsome. Jet black, sweet and melting. If you have never grown dewberries try the Lucretia. Price 3 for $25 \mathrm{c}, 12$ for $85 \mathrm{c}, 50$ for $\$ 2.00,100$ for $\$ 3.00$.

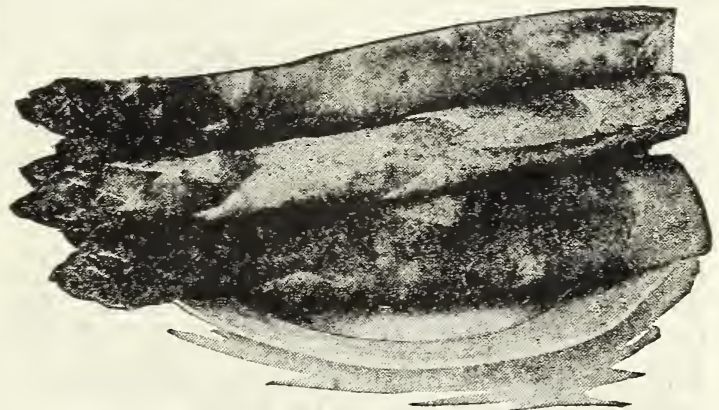

Mammoth White Asparagus.

\section{Asparagus Roots}

Columbian Mammoth-Every home garden should contain an asparagus bed. Once planted it will require little care, and there is no other vegetable you can plant that will produce a greater quantity of desirable, nourishing food from the same space. An ordinary sized bed, 6 by 10 feet, requiring 50 roots to plant, when established will furnish a daily supply for three or four persons for two months or more each season. Plant roots and save one or two years time as compared with planting seed.

Strong one-year roots 12 for $40 \mathrm{c}, 50$ for $\$ 1.00$, 100 for $\$ 1.50$

Extra strong two-year roots 12 for $60 \mathrm{c}, 50$ for $\$ 2.00,100$ for $\$ 2.50$.

\section{Rhubarb Roots}

\section{Choice Black Cap Raspberry}

Cumberland (The "Business Black Cap")Biggest black raspberry grown. This is offered with the assurance that it is the most profitable and desirable variety for home or market. Cum-

A few clumps of rhubarb in a corner of the garden will furnish a continual supply of material for pies and sauces during the early summer months. Price $15 \mathrm{c}$ each, 12 for $\$ 1.00$. 


\section{Hard TreEs AND PlantS S9 DEWBERRIES}

A

VARIETY of Blackberry that trails on the ground. In size and quality the fruit excells the Blackberry; very profuse bearer and reasonably hardy. Vines should be covered with straw or earth over winter in cold climates. The fruit of the Dewberry is highly prized as a market fruit, owing to its large size and quality.

Austin-Berries very much larger than those of any other Dewberry or Blackberry. It requires no trellis or stakes. The fruit is jet black and of very superior quality and flavor. For productiveness it outrivals all Dewberries. 10 for $75 c, 100$ for $\$ 4.00,1,000$ for $\$ 30.00$

Lucretia-See page 13.

\section{GOOSEBERRIES}

GOOSEBERRIES CAN BE EASILY GROWN

Gooseberries always in great demand by canneries and on markets-are sure croppers even when neglected. They can be shipped long distances and they keep well. Often are planted between the rows of trees in a young orchard. Bear second and third year.

Pearl-Heavy 'bearer, strong grower. Each, $35 \mathrm{c}, 10$ for $\$ 3.00,100$ for $\$ 25.00$.

Downing-A popular variety with bushes that grow very stocky. Immensely productive of medium to large size, pale green fruits, about 50 per cent larger than Houghton. Each 35c, 10 for $\$ 2.50,100$ for $\$ 25.00$.

Houghton-A pale red gooseberry of fine quality, medium sized and smooth. The bushes are very hardy, vigorous and produce a great amount of fruit. Especially fine for home use. Each 35c, 10 for $\$ 2.50,100$ for $\$ 25.00$.

\section{CURRANTS}

Fay's Prolific-True to its name, it is very prolific, with fruit of very large size. Popular with most growers, and does particularly well on light soils. Each 35c, 10 for $\$ 2.50,100$ for $\$ 20.00$.

Perfection-A new variety of great merit. One of the best on the market, being productive, extremely large, and easy to pick. The flavor is very fine. In size it even exceeds the Fay. One of the most popular varieties, having won medals and diplomas wherever placed on exhibition. Each 50c, 10 for $\$ 4.00$.

Red Dutch-An old, well known and popular red currant, with berries of medium size, dark red. A strong, tall, upright grower. Each $30 \mathrm{c}$, 10 for $\$ 2.50,100$ for $\$ 20.00$.

\section{Gentlemen:}

Taiton, Texas, Feb. 23, 1920.

Strawberry Plants came In good condition. They look fine. Thanks. Yours truly, JOE DRAPELA.

\section{Dear SIrs:}

Carbondale, III., April 12, 1921.

I have received my Strawberry Plants and they are fine.

502 W. College St.

HATTIE I. MAYHEW.

Hesston, Kansas, April 29, 1921.

The Strawberry Plants you sent came through all $O$. $K$. and I set them out and they are doing fine. Please accept my thanks for the Ruben Peach Tree sent as a premium.

Yours respectfully, MRS. C. A. DAILEY.

\section{New Dewberry Premo}

$\mathrm{Much} 11 \mathrm{ke}$ L u c r etia, but very distinct, and exceedingly e a r l y, being seven to ten days ahead and all cleaned off when Lucretia is b e g i nning. Quality and size uniform. W a s found in a $\mathrm{Lu}$ cretia patch. Price 10 cents each, $\$ 1.00$ per dozen, $\$ 5.00$ per $100, \$ 40.00$ per 1000.

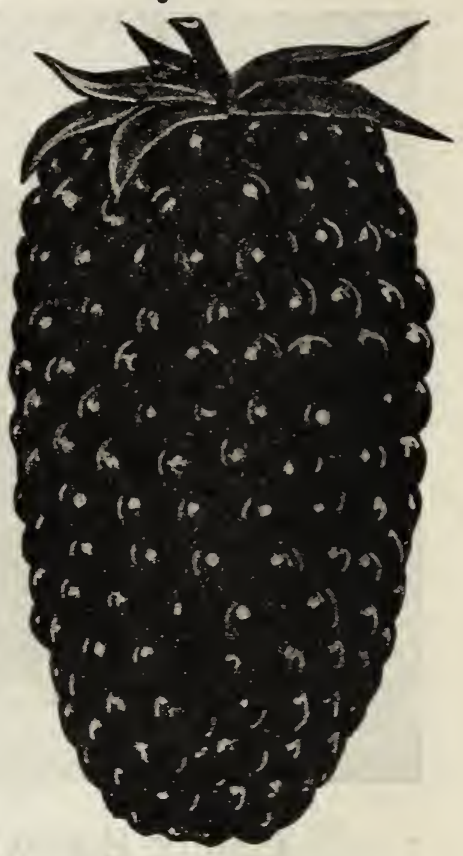

\section{HORSERADISH}

We have a little booklet on growing and marketing Horseradish, telling all about the cultivation, the packing and selling this remarkable herb. Some of our customers are making $\$ 900$ per acre in this work. The book is a little gem and will be sent you by mail postpaid for 10 cents.

\section{Moneymaker Horseradish}

A new variety which is proving to be a veritable gold mine to market gardeners; a rapid grower of very large roots. It is much earlier than the old variety of Horseradish, and produces a much larger crop. Growers are able to get their crops into the market while prices are high, making it the most profitable of all root crops of this class. Easy to grow, matures quickly and produces abundantly. Should be in every commercial and home garden. Prlce $10 \mathrm{c}$ each, $\$ 1.00$ per dozen, $\$ 8.00$ for 100 .

\section{Ponca Clty, Okla., Feb. 27, 1920}

\section{Gentlemen:}

Recelved the Strawberrles In excellent shape. Am more than pleased wlth them.

Thanklng you, I remaln,

Yours respectfully,

MRS. L. EMERY. 


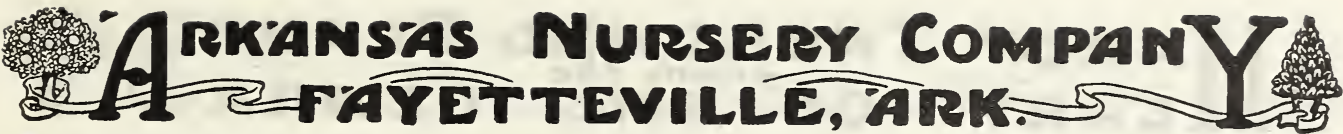 A'RKANSAS NATIVE SEEDLING FRUIT}

\section{Arkansas Seedling Grape}

A large black grape of delicious flavor, a very prolific and annual bearer. The original vine has not missed a crop for several years. Price $25 \mathrm{c}$ each, $\$ 2.00$ per dozen.

\section{Seedling Peach}

Genuine Old Time Indian Peach, grown from selected seed, not guaranteed to reproduce true. Very desirable for hardiness; prolific bearer. Price $25 \mathrm{c}$ each, $\$ 2.00$ per dozen.

\section{Snow Peach}

A white free stone peach of medium size, grown from selected seedlings. The tree can be distinguished from any other tree by its green bark. Price 25c each, $\$ 2.00$ per dozen.

\section{Arkansas Seedling Crab}

We recommend this variety for its hardiness. The fruit is of good size and very desirable for preserving. Price $35 \mathrm{c}$ each, $\$ 3.00$ per dozen.

\section{Arkansas Native Persimmon}

A very large seedling variety. Price, $50 \mathrm{c}$ each.

\section{The Giant Himalaya Berry}

It grows a cane twenty to thirty feet in length if left untrimmed. It is usually trained to a wire or over a trellis as a grape vine. The berries are almost coreless and very rich; they need very little sugar in cooking. They have a flavor all their own, and are surpassingly good for pies, jellies and jams. Perfectly hardy; makes enormous yield. Introducer claims that from two vines he picked $\$ 31.00$ worth of fruit one year, and $\$ 54.00$ worth the next. It is well worth giving a trial. Our plants are genuine. Price 20 cents each, $\$ 1.50$ per dozen, $\$ 10.00$ per 100.

\section{Strawberry-Raspberry}

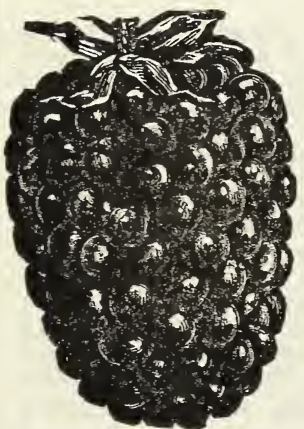

Valuable for the extreme North, as the fruit is borne on the young growth, and is of course hardy in any climate. This is an entirely new fruit, both in habit of growth and form of fruit. Bushes grow one to three feet high and are covered with Raspberries in the shape of Strawberries. Price 10 cents each, $\$ 1.00$ per dozen.

\section{Japanese Wineberry}

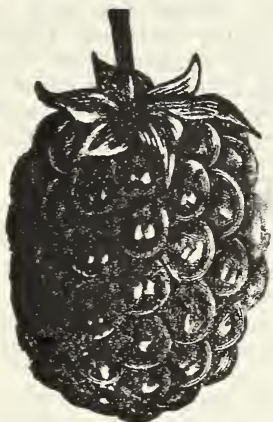

This interesting plant belongs to the Raspberry family. The fruit is borne in large clusters and each berry is at first tightly enveloped by the large calyx, forming a sort of burr. For jelly making, canning and preserving it is without an equal. Price 15 cents each, $\$ 1.50$ per dozen, by mail, postpaid.

\section{Ozark Huckleberry}

This delicious little berry is a native of the Ozark Mountain range, remarkable for its fine flavor, is a choice fruit for jam, pies and fruit cake. Grows luxuriant, very hardy: a prolific bearer and when given a small amount of attention produces regular annual crops. Will grow on almost any kind of soil, and when once set, is there permanently, never having to be renewed. Each $15 \mathrm{c}, \$ 1.50$ per dozen.

\section{Crystal White Blackberry}

Berries of fine, translucent white, of good size, sweet and pleasant. Canes prolific, but not entirely hardy. Should be planted near other sorts to fruit well. Price 10 cents each, $\$ 1.00$ per dozen.

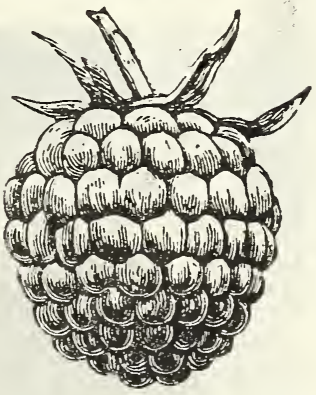

\section{Improved Dwarf Juneberry}

A good substitute for the large or Swamp Huckleberry. The fruit is borne in clusters, and is reddish-purple in color and changing to a bluish-black. In flavor it is a mild rich subacid, excellent as a dessert fruit or canned. Price 25 cents each, $\$ 2.50$ per dozen.

\section{Paw-Paw or "Arkansas Banana"}

A small tree with purple or whitish flowers and handsome foliage. The large fruit is edible and improves by cultivation. Hardy as far north as the middle of Nebraska. Worthy of more extensive planting. Very desirable as an ornamental tree. Price of first-class trees $\$ 1.00$

Bayside, Texas, March 31, 1921

I received the trees all $O$. $K$. and many thanks. Was waiting to see the outcome of it. Accept my thanks again and when need to make another order you shall have it.

MRS. PRISCILLA OIINGER. 


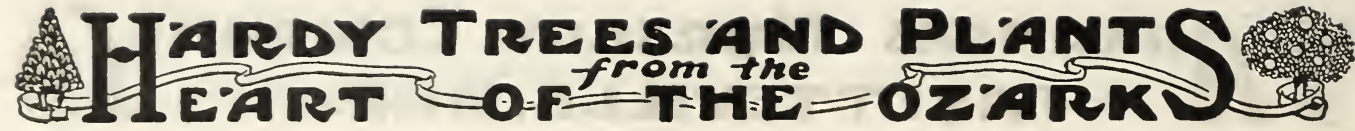 HOW TO GROW THE M'DONALD BERRY}

DLANT two rows of McDonald and one row of Dewberries or Blackberries to polenize, for every two rows of McDonald planted. Set rows six or seven feet apart and plant every eighteen inches or two feet in the row. The McDonald berry will yield about 100 quart crates per acre where properly cared for and people have found them to be very profitable. They sold this year for $\$ 5.00$ per crate, making $\$ 500.00$ or more per acre.

After you get the McDonald started the third year mow them off and rake and burn. Do this every third year. Blackberries are a great deal cheaper grown than the Strawberry. They do not require the cultivation that the Strawberry does and any kind of ground is good enough for the Blackberry and they will sell in any market.

\section{Blackberry By-Products}

Besides being eaten fresh, the blackberry is dried, canned, made into jam, jellies, and other preserves, and pressed to extract the juice. Dried blackberries are not used as much as formerly, because more convenient methods of preserving have been developed.

The introduction of the lacquered-tin can, which does not discolor the contents as does the ordinary tin when it comes in contact with this acid fruit, has assisted in the rapid expansion of the blackberry-canning industry. The berries may be preserved in a sugar solution or, as is more customary, preserved without sugar by heating. This latter process is very Inexpensive and is more satisfactory for the trade, since berries put up in this way can be used for many purposes for which berries preserved with sugar would be unsuitable.-From Bulletin No. 643, U. S. Department Agriculture on "Blackberry Culture." Send for this Bulletin. It is free.

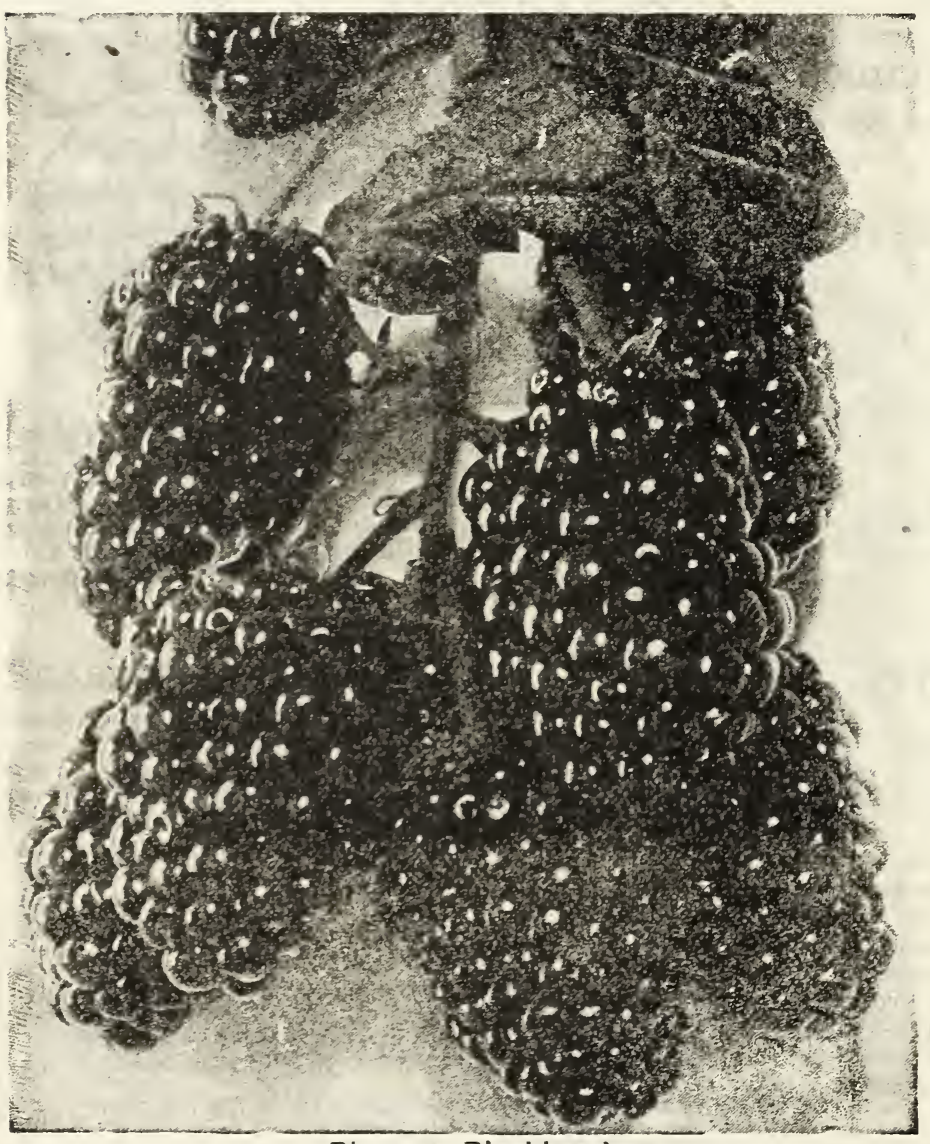

\section{BLACKBERRIES Pay Big Dividends}

There is a great and increasing demand for blackberries. There is no fruit capable of yielding greater profits. There will usually be from 150 to as high as 250 cases of 24 quarts from an acre, and that is usually consistent to figure on an average of $\$ 100.00$ to $\$ 150.00$ per acre after paying for picking, boxes and express.

For field culture plant three feet apart in rows six feet apart. For garden culture plant four feet apart in rows five foet apart.

If planted between the rows of young trees in an orchard to maturity, they will produce fruit two seasons after planting.

Blowers Blackberry-"The giant of all blackberries." The fruit is exceedingly sweet. This is a first-class shipper. The season of ripening is from the middle of July until frost, with the bulk of the crop maturing in the month of August. It is a hardy variety. It has endured 20 degrees helow zelo. 10 for $\$ 1.50, \$ 6.00$ per $100, \$ 50.00$ per 1,000 . Dallas Blackberry- $A$ T e $\mathrm{x}$ a berry, large, black, firm, and a strong grower. Ripens in midSrice $\$ 5.00$ for $100, \$ 50.00$ for 1,000

Early Harvest-O ne of $\mathrm{the}$ earliest blackberries in cultivation a compact dwarf grower, fruit rather small and of good quality. heavy bearer. 10 for $\$ 1.00, \$ 5.00$ per $100, \$ 40.00$ per 1,000 .

McDonald-Enormously productive, outyielding any other known variety of blackherry. Ripens two weeks before Early Harvest, which is the earliest ripening of all blackherries. Can be sold for extra price before any other varieties are on the market. 10 for $75 \mathrm{c}, 100$ for $\$ 4.00,1,000$ for $\$ 30.00$.

Rathbun-Very large size. 10 for $\$ 1.00,100$ for $\$ 6.00,1,000$ for $\$ 50.00$

Robison Blackberry-Large, de licious berries, very prolific, and a valuahle berry for the Southwest. $\$ 5.00$ for $100, \$ 50.00$ for 1,000 .

\section{Clippers Gap, Calif.,} August 12, 1921.

\section{Gentlemen:}

I got 600 Strawberry Plants from you last spring and I will say I never saw such nice plants, or had plants to grow nicer. Every one of them lived in spite of our not being able to get them set out for three or four days after receiving them, on account of the weather.

MRS. SARAH CHURCH.

Southton, Texas, Feb. 25, 1921. I received the Strawberry Plants. They were in fine condition. You may use my name. LAWRENCE ROSENBACH. 


\section{A RKansas Nursery COMPANYY}

\section{FRUIT AND SHADE TREES}

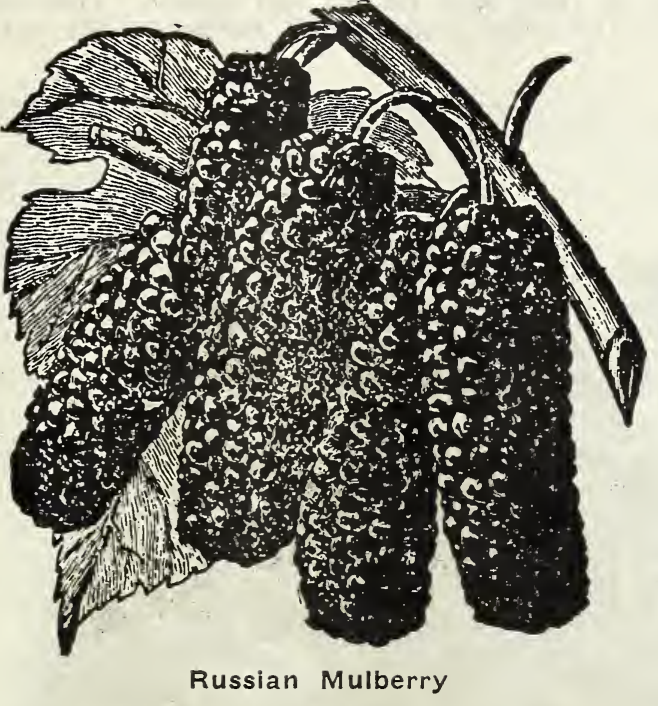

Ever-Bearing Mulberry Trees

These trees are exceedingly rapid growers, and come into hervy hearing in three or four years. Then for months they continue to ripen large quantities of fine, large fruit good to eat and of the highest value for poultry and hogs, which can be penned around trees and kept fat and healthy. No raisers of chickens or poultry of any kind can afford to be without them if they cost $\$ 5$ a tree.

Downing Everbearing-This popular variety is a good grower and bears heavily. Each $\$ 1.00$.

Hicks Everbearing-A fine grower and a heavy bearer. Ripens through June, July and August. Each \$1.00.

Abundance Everbearing-Very large, black, handisome; a sweet, rich and excellent variety. Each $\$ 1.00$

\section{Russian Mulberry}

This tree has been planted very extensively in the western atates for the past fifteen years, and we know of no other tree that will stand as much drouth and neglect and yet make a good growth each year. It makes a very good shade tree, holding its leaves late inco the fall; and for a hedge, without thorns, it has no superior. Trees commence to bear at two vears old; fruit resembles the blackberr!, and will ripen from July to 1st of September. Each 50c. 10 for $\$ 4.00,100$ for $\$ 25.00$.

\section{Japan Persimmons}

This royal fruit from Japan is deservedly popular. Most beautiful in foliage and fruit, and the most delicious of all fruit. It gains in the estimation of people everywhere when they learn its value. We offer best obtainable varieties, grafter on native stock. Each $\$ 1.50$.

Cedar Nook Farm, R. F. D. 1, Box 56 Springfield, Mass., May 10, 1921.

My Strawberry Plants arrived in good con. dition and 1 am more than pleased with them. Thanking you for your prompt atten. tion, I am, Yours very truly, E. W. WINGER

\section{Nut Trees}

Stuart Pecan-Pecan trees grow in almost any climate and on almost any kind of soil. The Stuart is a popular variety. It is hardy. Withstands freezing weather. Produces a nut high in quality and of excellent flavor. Each $\$ 1.50$.

Japan Wainut-Perfectly hardy; a rapid grower, bearing young and abundantly. Highly prized as an ornamental tree. Nuts resemble butternuts. Each $\$ 1.00$.

English Walnut-These seedlings have been thoroughly tested. A soil that will grow apples is pretty sure to grow English Walnut. These nuts sell at 40 to 60 cents per pound. Two or three-foot trees usually give the best results. Each \$1.00.

Butternut-A fine native tree, producing a large, longish nut, highly prized for its sweet, oily, nutritious kernel. Each $\$ 1.00$.

Chestnut, American-The fruit of this wellknown native tree need hardly be described. We believe it is considered by all to be the best of all nuts, whether native or foreign. Each, \$1.00.

Flibert-Tree of easy culture, succeeding well In almost any soil. Bears early and abundantly. Nuts almost round, rich and of excellent flavor. Each 50c.

\section{Fig Bushes}

This luscious and mildly laxative fruit, old almost as time itself-the fruit that refreshed and nourished the men who made history in Bible days, is about the easiest of all to grow. After the first year or two it needs no further attention unless you are far enough north for the branches to be winter killed. Price, $\$ 1.00$

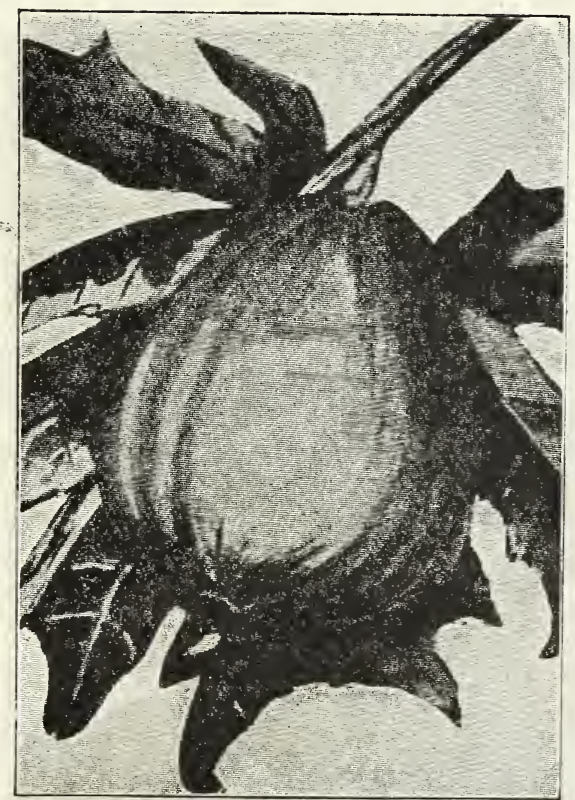

Flgs furnish food and medicine. 


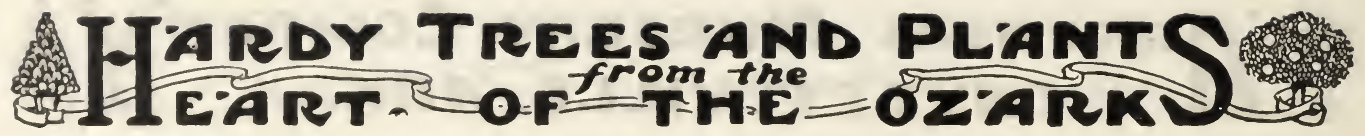 ORNAMENTAL TREES}

RNAMENTAL Trees are ever popular because of their rare beauty and utility. They add value to the property and serve as windbreaks to fruit growers and farmers. We carry fast growing kinds at reasonable prices.

EIm-A large tree with spreading branches. Leaves deep rich green. Extensively planted. Each $\$ 1.00$.

Maple (sugar) - A good sized variety with wide, spreading branches and beautiful and abundant foliage. A rapid grower. A popular variety. Each $\$ 1.00$.

Poplar (Norway) - A rapid growing tree of great hardiness. Used for windbreaks, street trees and ornamental planting. Hardy and widely planted. Each 50c.

\section{Flowering Shrubs}

The price of all flowering shrubs is $75 \mathrm{c}$ each.

Althea or Rose of Sharon (Hibiscus Syriacus)-Large assortment, many shades of color and type of form and habit, woth single and double.

Calycanthus (C. Floridus)-Sweet scented purplish flowers in spring.

Deutzia Gracllis-Dwarfish, flowers pure white, bell shape. Blooms early in April.

Elder, Golden (Sambucus Aurea)-The yellowish green tints of foliage, the white flowers, and the fruits are very pleasing.

Hydrangea Paniculata Grandiflora-Immense panicles of pure white flowers in July, lasting for several weeks.

Hydrangea Arborescens, or Hill of Snow-Immense panicles of pure white flowers; blooms continuously from June to August. Should be planted in partial shade.

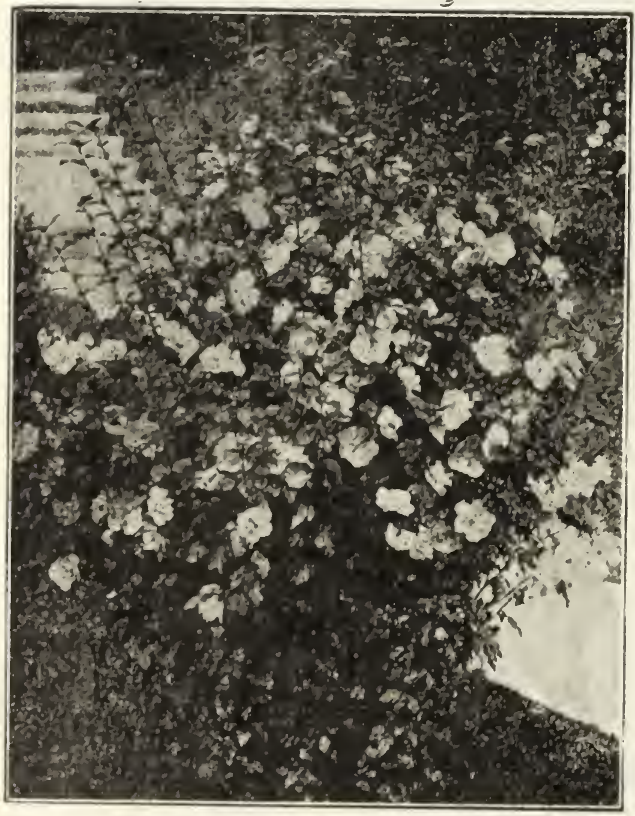

Aithea or Rose of Sharon

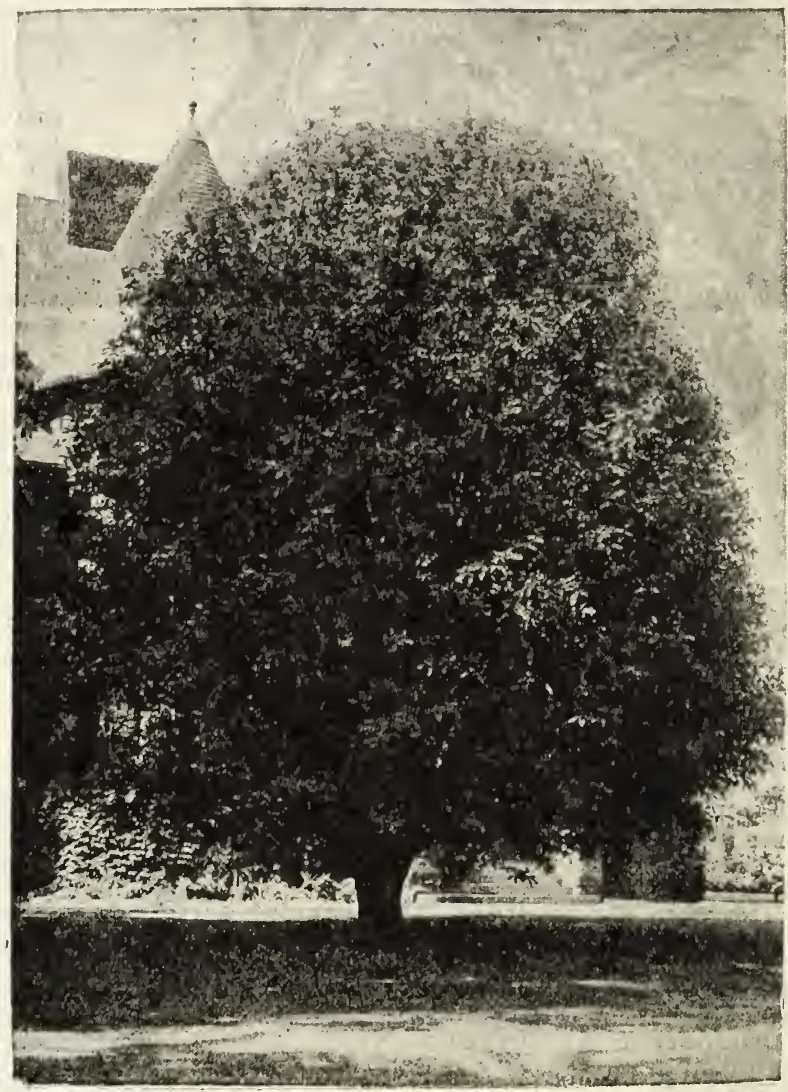

EIm.

Lllac (Syringa)-Well known and popular. Purple flowers, exquisite fragrance.

Lilac, White (S. Persia Alba)-This is a variety of Persion. White flowers.

Prunus Pissardi-Small Plum tree. Fruit and new growth very distinct purple.

Snowball (Viburnum Opulis Sterlis)-Produces large globular clusters of wlite flowers in April; an old favorite.

Snowberry, Red (Symphoricarpus Racemosus Rubrus)-Graceful native shrub with slender drooping branches; white flowers in spring followed by profusion of red berries in fall. Very hardy and drouthenduring.

Snowberry, White (Symphoricarpus Racemosus)Similar to red, but berries white.

Splrea Anthony Waterer-A new dwarf Spirea, variegated foliage. Flowers dark crimson; from May until frost.

Splrea Van Houttel-A strong shrub, covered with clusters of white flowers.

White Fringe-A popular and much admired shrub of moderate growth and rounded form with large dark green glossy leaves and drooping panicles of beautiful white fringe-like flowers.

Welgela Rosea (Diervilla)-Long spikes of pink llowers: very hardy. 


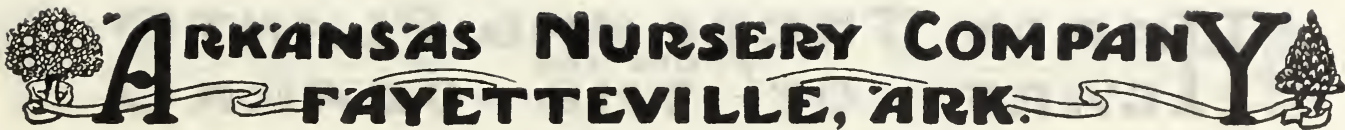 ROSES}

$\mathbf{I}^{\mathrm{T}}$ WOULD be impossible to exaggerate the beauty of the rose. The very name suggests beauty and fragrance. It is the flower we love the best and deserves all the affection and care we

bestow upon it. To have roses all summer is now a possibility, even with but a small garden. Our list comprises reliable, hardy varieties, producing a large range of colors, which will bloom from spring till November. It is a question of careful selection and we will gladly assist you.

Price of neld-grown Roses, $\$ 1.00$ each, $\$ 9.00$ per dozen.

Amerlcan Beauty-Large, globular, pink, shaded with carmine; delicious odor.

Anna de Dlesbach-This rose was introduced in 1858 and is well known. It is a beautiful shade of carmine-pink; flowers are large, full and very fragrant. On account of its hardiness it's a fine garden sort.

Caroline Testout (The Oregon Rose)-A large rose, especially adapted for table decoration. Deep pink in color, beautiful buds.

Frau Karl Druschki-Pure white; large long buds, perfectly able. It is the best white Hybrid Perpetual known and one of the best novelties of recent years. Will grow wherever other roses can be grown.

Grus an Teplitz-Beautiful crimson red, wonderfully free flowering. One of the finest for outside show.

General Jacqueminot-Bright crimson; large but not full, although very effective; hardy and fragrant. Famous the world over.

Kalserin Augusta Victoria-Pure white, shading to lemon. Flowers large, fine formed, borne singly on strong, upright stems; continues beautiful even when fully expanded. The fragrance is distinct from other varieties, being a combination of tea and magnolia. Free flowering and vigorous, with glossy foliage.

Killarney-Noted for its freedom of bloom and the large size of its intensely fragrant flowers. Buds are large, long, and pointed. Color flesh, shaded white suffused pale pink.

La France-Probably the best known rose in cultivation. Both flowers and buds are of beautiful form and large size; very sweet; color delicate silvery rose, changing to silvery pink. Starts to bloom when very small and continues until stopped by frost.

Mme. Franclsca Kruger-Deep shade of copper-yellow flowers which bloom continuously. Excellent for bedding and massing.

Mrs. John Lang-Very free flowering, commencing to bloom early in the season, and continuing until autumn. Color a soft delicate pink. with a satin tinge, very fragrant.

Margaret Dickson-Magnificent form, white with large pale flesh center. Petals very large, well shaped and of great substance. Follage very large, dark green. Fragrant. A fine varlety.

Madame Plantier-Pùre white, above medium size, produced in great abundance early in the season. One of the best hardy white roses, cometlmes called the cemetery rose.
Mme. Gabriel Luizet-Very distinct pink large, cup-shaped; fragrant. It has no rival as an exhibition rose.

Marshall P. Wilder-Cherry carmine, large size. Good form, very fragrant, perpetual bloomer, vigorous grower; very valuable.

Paul Neyron-Deep red rose; splendid foliage and habit, with larger flowers than any other variety. Free bloomer.

Salet (Moss)-Bright rosy red; a vigorous grower; abundant bloomer, seldom surpassed; pretty in bud.

Ulrich Brunner-Bright cherry-red; very attractive; flowers of fine form carried well upon the plant; petals of great substance; plant hardy, vigorous, and resists mildew.

\section{Climbing Roses}

Prlce of Climbing Roses $75 \mathrm{c}$ each, $\$ 8.00$ dozen.

Crimson Rambler-This is undoubtedly the most popular of all roses. It is hardy, wonderfully free flowering, rich glowing crimson, intensely bright and vivid in color. The plant is a strong rampant grower, making shoots 10 to 12 feet long after the first year. The flowers are produced in great trusses, pyramidal in shape, often 25 to 30 in a cluster, fairly covering the plant from the ground to the top with a mass of bright glowing crimson. This is the most wonderful rose introduced in the past thirty years.

Dorothy Perkins-An extremely vigorous and hardy rose of the rambler type; a good companion for Crimson Rambler. It is shell pink in color, very free flowering and entirely reliable. The plants are even hardier than Crimson Rambler.

White Dorothy Perkins-Same as the pink Dorothy, except in color. which is white.

Yellow Rambler (Goldfinch)-Light canary shade; clusters smaller, individual flowers larger than Crimson.

Climbing American Beauty-The latest triumph in American rose growing-the true climbing American Beauty in all its promise and glory. The same as American Beauty practically. Larger flowers, each produced on separate stems, vivid rosy-crimson in color, with delicious fragrance.

Golden Clty, Mo., April 10, 1921.

Recelved the Strawberry Plants all rlght. Was well pleased with them. "WIII try next year for an order of trees.

MRS. S. M. POTTER. 


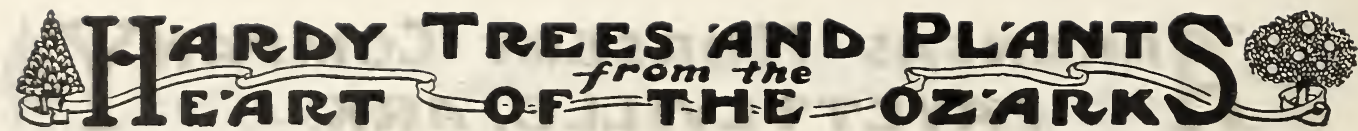

\section{SPRING BULBS}

\section{CANNAS}

Cannas are the Most Popular Bedding Plants.

The President-Height 4 feet. In color, a rich, glowing scarlet, and the immense, firm, rounded flowers, 7 inches across when open, are produced on strong, erect stalks well above the large, rich green foliage. Superior to any other red variety. Price $25 \mathrm{c}$ each, 5 for $\$ 1.00,25$ for $\$ 3.00$, delivered.

Burbank-The color is a pure, strong, canaryyellow, with some red spots in throat. The flower is often 4 to 5 inches across. $10 \mathrm{c} \mathrm{each,}$ $\$ 1.00$ per dozen.

Special KIng Humbert-The grandest Canna ever offered. Large heart-shaped leaves of purple madder brown over bronze, the dark ribs sharply defined, crowned with immense heads if orchid-like flowers. $15 \mathrm{c}$ each, $\$ 1.25$ per dozen.

Wyoming-Seven feet, purple foliage. One of the most majestic Cannas. Blossoms orange colored, true orchid shape, with large rounded petals that flap and flutter in the breeze like glistening silken flags. $10 \mathrm{c}$ each, $\$ 1.00$ per dozen.

\section{SPECIAL $\$ 1.00$ OFFER}

We will make a selection of varieties for you for a complete Canna bed and will choose varieties that will please you. Will send you 20 bulbs for $\$ 1.00$, enough for a large bed.

\section{DAHLIAS}

The splendid qualities and gorgeous beauty of the present-day Dahlia have won for it a place at the head of the most important garden plants. None are easier to grow, respond more freely to care and attention, or flower more freely. Few cultivated plants have a wider range of color. Plant about May 1st in a moderately rich soil, covering the tubers three inches deep. Price 25c each, $\$ 2.00$ per dozen.

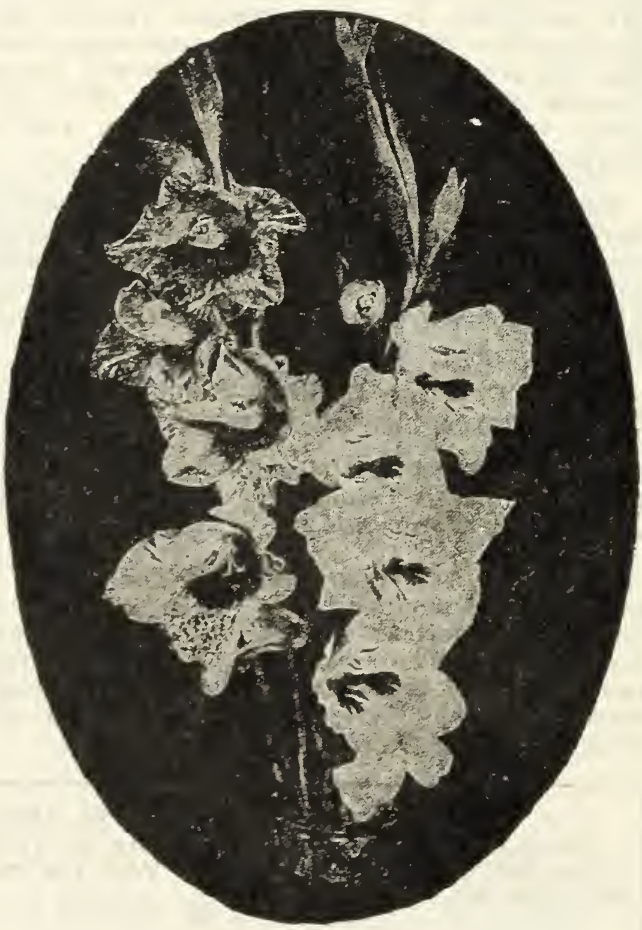

Gladloll.

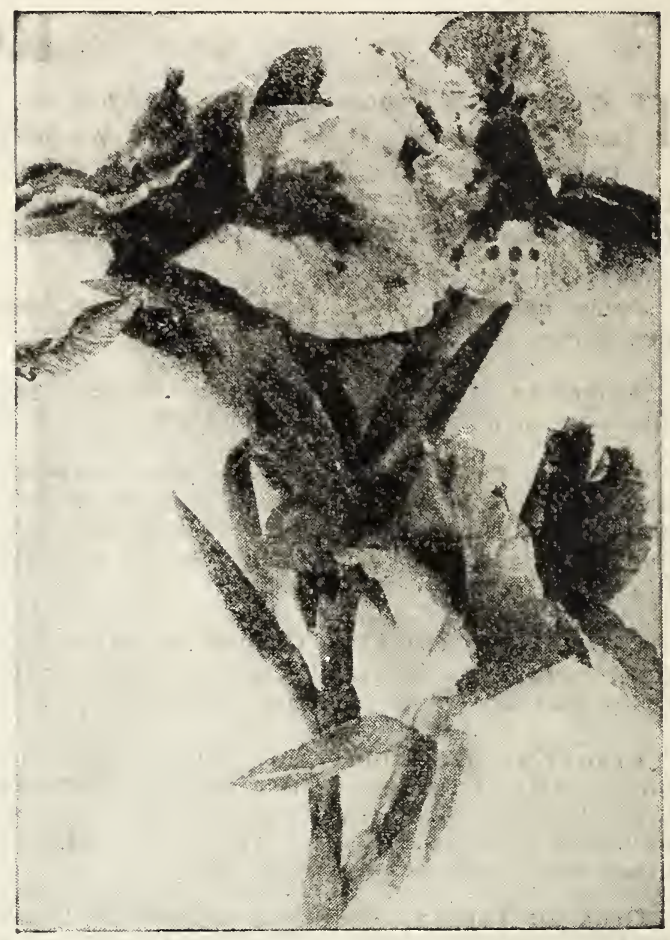

Cannas are Easy to Grow.

Tuberoses-One of the most delightfully fragrant and beautiful of the summer-flowering bulbs. By skillful management a succession of flowers may be obtained all the year round. Each 10c, $\$ 1.00$ per dozen.

\section{LILLIES}

Lilllum Auraturm (Gold Banded Japan Lily)The largest and most beautiful of all the Japanese lilies. The flower is ivory white, with a central bank of bright yellow and numerous deep purple spots. Price 50c each.

\section{DASHEENS}

Belong to the same family as the Elephant Ear, and resemble them somewhat, but grow more upright. Price 20c each, 3 for 50c, postpald.

\section{GLADIOLI}

The Gladioli is the most satisfactory, the most desirable and the most popular of all garden bulbs. Nothing else of the kind costs so little, and nothing else grows and blooms so rapidly for anybody and everybody, in any soil or climate.

\section{OUR SUPERB MIXED GLADIOLI}

Our Mixed Gladioli are made up from splendid named sorts, brightest and most varied colors, white, yellow, pink, rose, blush, intense scarlet, carmine, violet. Each $10 \mathrm{c}, 75 \mathrm{c}$ per dozen.

\section{NOVELTY}

Physalis Franchetl or Chinese Lantern Plant

An interesting perennial of rapid growth, producing small white flowers, followed by green lantern-like pods which in autumn turn to a brilliant red. These pods average 2 to 3 inches in diameter; they become dry and retain their size, shape and color a long time. A few stalks of Lantern Plant placed in an empty vase makes a beautiful bouquet, which will last all through the winter months. Price 25c each. 


\section{A RKansas Nursery COMPANY PERENNIAL PLAN'IS}

Everblooming Butterfly Bush (Buddleia Variabilis Magnifica)-This is one of the most valuable and beautiful new plants introduced for years. It was recently discovered in Western China, and thrives in all parts of the United States. It is a hardy perennial, blooming practically all summer, and blooms the first summer from small plants, continuing even after frost. Its hardiness, ease of growth, beautiful color, and piquant fragrance makes it popular everywhere. It is fine as a specimen plant, as a hedge, or as a background, but should not be planted in sod or extreme shade. It gets its name from the fact that it is very attractive to butterflies, and they come from everywhere to feed on its nectar. One-year plants 50c, 2-year 75c.

HOLLYHOCKS-These are known and loved everywhere, and no old-fashioned garden is to the high wall of a house. $7 e$ can supply a get them in front of your other flowers, as they grow so tall they would hide them. Five to 7 feet high $10 \mathrm{c}$ each, $\$ 1.00$ per dozen

Japan Iris-The flowers are of enormous size, averaging eight to ten inches across, charming hues and colors, the prevailing colors being white, crimson, rose, lilac, lavender, violet and blue. The Japan Iris is perfectly hardy and flowers in great profusion in July and August. Each $15 \mathrm{c}$, $\$ 1.00$ per dozen.

Perennial Phlox-Instead of the small, dullhued flowers of olden times we now have immense trusses, all bright and showy, the individual flowers three times the size of the old varieties, and the colors ranging from the pur-

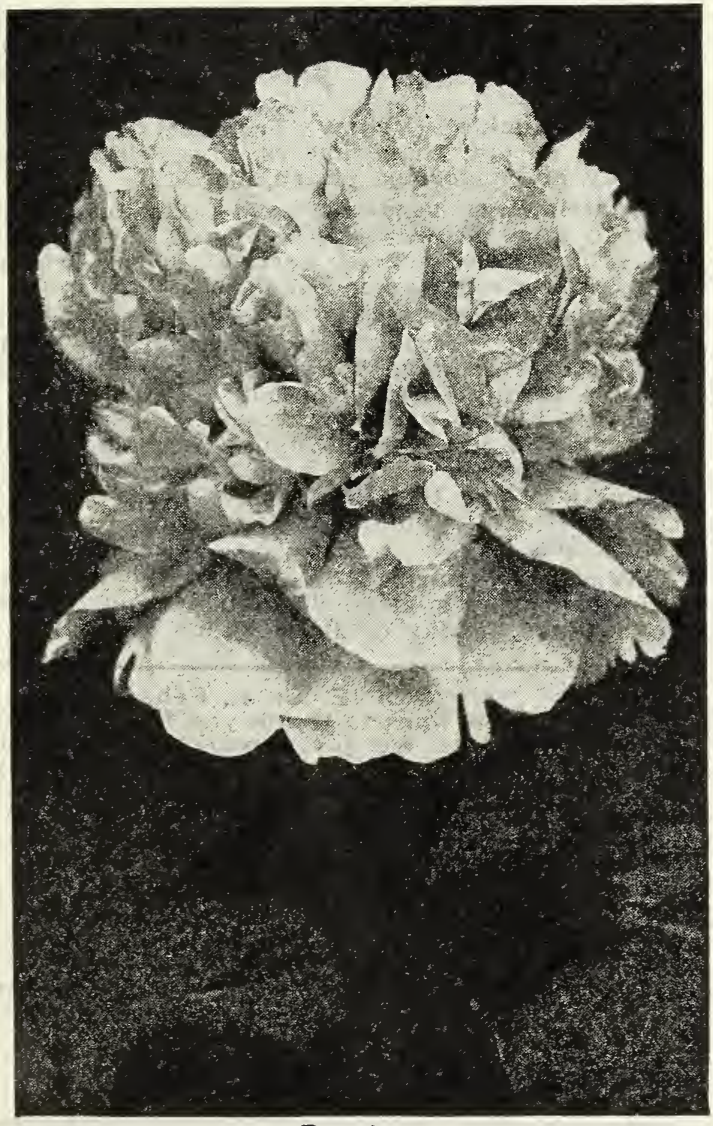

Peonlee

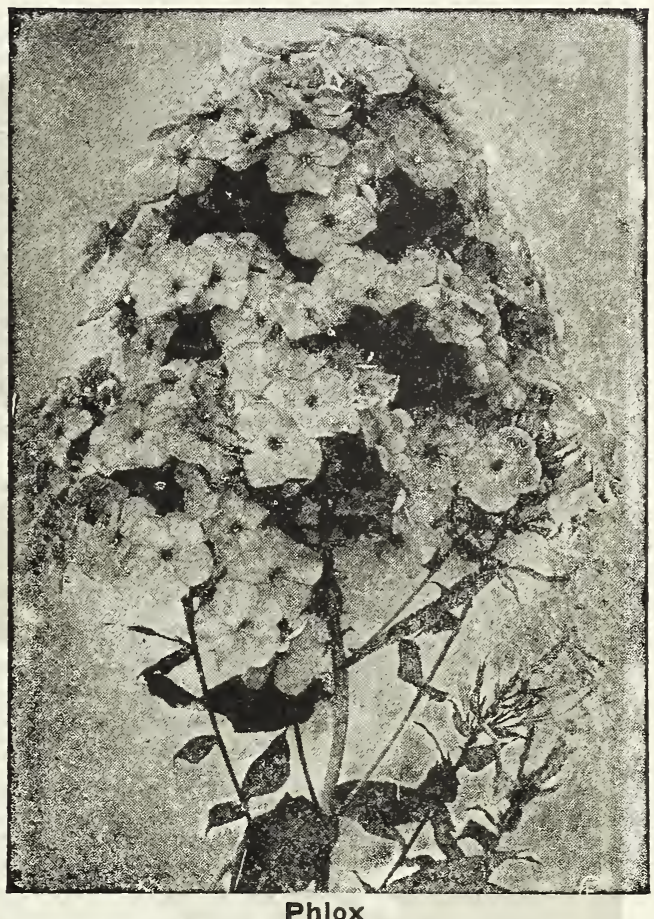

est white to violet. With Perennial Phlox a show of brilliant flowers can be had from June until November. Perfectly hardy. Choice shades of red, white and pink. Each 25c, $\$ 2.00$ per dozen.

The Foxgloves are quite stately and highly ornamental plants when well grown, with flower stems at least three feet in height. They are fine for the mixed border, or planted singly in half-shady places near a walk or drive. The racemes of flowers are often two feet in length, containing scores of the prettily spotted thimble-shaped flowers. Perfectly hardy. Mixed varieties, $50 \mathrm{c}$ each.

\section{PEONIES}

Peonies, especially the modern introductions, are probably the most valuable, and most beloved of all perennial plants. Planted in sun or semi-shade, in single clumps or long beds, or bordering lawns, shrub rows, and carriage drives they give a grand display of large, frag. rant blossoms of brilliant colors during June, followed by their exquisite foliage, which is very ornamental during summer months. They are also most effective for home and table decorations, and last longer in water than many other perennials. Avoid buying cheap peonies. They require just as much care as the better kinds, and are disappointing in the end. We grow only varieties that we have thoroughly tested at our trial grounds, and here offer the grandest peonies in commerce.

Planting-Peonies may be planted in spring as soon as the frost is out of the ground. Orders should be sent in at once, so that we can forward when weather permits. Avoid planting too deeply, as this is often the cause of shy blooming; 2 or 3 inches of soil over the crown (eyes), being sufficient. After planting give a hearty mulching of rotten stable manure, and do not transplant the clumps for at least nve years, and then only if very necessary. 


\section{HARDY TREESAND PLANTS ORNAMENTAL VINES}

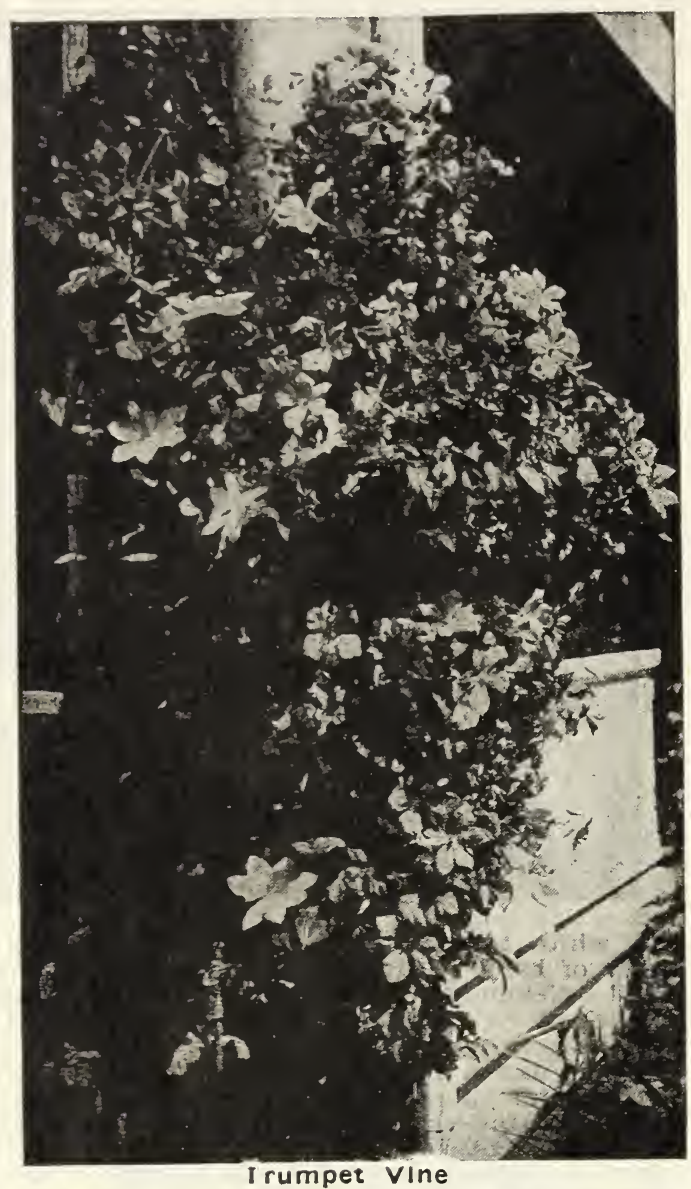

Everyone likes vines on a house. They are practical, beautiful and home-like. They give shade to a window, protection to a porch and beauty to a pillar. Some of the varieties will climb and stick tight to a brick wall.

I wish I could show you pictures of their beautiful colors. They are just ravishing. You get the golden yellow in the Honeysuckle; the orange-scarlet in the trumpet vine; the royal purple and violet in the Jackmanni Clematis; and the snowy white of the Paniculata Clematis. A blooming vine at your front door is a constant beneliction.

Boston Ivy-Leaves are small and ivy-like in form. They overlap and form a dense sheet of green. A splendid clinging vine. Needs winter protection. Each 40c.

Cinnamon VIne-Grow from a root like a sweet potato, which is hardy and lives in the ground for years. A rapid grower when well established. Each 25c.

Clematis, Purple (JackmannI)-The queen of all vines for size and richness of flowers, which are violet purple, 3 to 4 inches in diameter. Needs winter cover. Each $\$ 1.00$.

Clematls, White (Panlculata)-The best, bardy white clematis. Vigorous, sweet-scented pure white flowers. Blooms late in summer. ench The
Most vines do best planted In the spring -the earller the better. I do not advise fall planting for them. If planted In a row along a wall or fence they should usually be planted about 8 feet apart. On a bullding it Is usually best to plant one or two at each window or pillar to be covered.

Trumpet Vine (Bignonia Radicans)-A robust, woody vine, climbing high and twining tightly with numerous roots along its stems. Great, leathery, trumpet-shaped flowers of orange scarlet, clustering all the tips of the branches, bending them gracefully with their weight. In bloom nearly all summer. Extremely valuable for covering old stumps or walls; wherever a showy flowering vine is desired, it will be found most useful and pretty. Can also be grown as a small tree or bush. Each 30c, 3 for $75 c$.

Honeysuckle (Hall's Evergreen)-Pure white flowers. Very fragrant. Dark green, glossy foliage. Keeps green till Christmas. A fine variety. Each $50 \mathrm{c}$.

Kudzu-A remarkable climber. Grows 70 feet in rich soil in one season. Fine for arbors, old trees and porches. Each 50c.

Honeysuckle (Scarlet Trumpet)-A good hardy climber. Free bloomer. Flowers the shape of a trumpet. Fine for a trellis. Each 30c.

Honeysuckle (Yellow Trumpet)-Similar to above except that flowers are yellow. Very hardy and vigorous. Each $30 \mathrm{c}$.

Matrimony Vine-An old-fashioned hardy shrub vine, grows anywhere, and covered with a profusion of scarlet berries. Good to cover walls or steep banks. Each 30c.

Madelra Vine-Grows from tubers like potatoes which should be taken up and kept in the cellar over winter. Very easily grown and will thrive in any location or soil. Will grow 12 to 15 feet high. Waxy dark green, heart-shaped leaves and racemes of fine white bloom, very fragrant. One of the best vines for planting thickly along the front edge of a porch for quick effect. Should be bought by the dozen. Each 30c.

Wistarla (Purple)-A rapid hardy-growing vine. Produces large drooping purple clusters of flowers in May or June. Each 50c.

ALINE, Okla., Feb. 25, 1921

Just a few lines to thank you for our order of fruit trees we just received from you. They were in fine condition and certainly thank you for the re-placement of these four trees. We surely will recommend your company to our friends and neighbors. Thanklng you again, we are, As ever, J. W. WILSON.

Bridgeport, Kansas, March 21, 1921.

My order of Raspberries and Apple Trees arrived in fine conditlon and were all right. They are out and growing. Thanks.
R. 2, Box 21. Respectfully, P. W. SWENSON. 


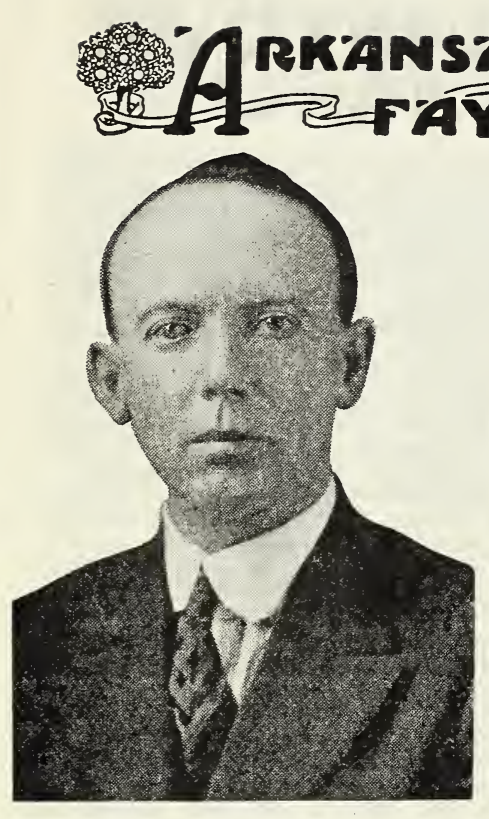

\section{MEET OUR NEW SEED MAN}

Dear Seed Buyers, Anywhere:

Owing to the crowded space in our catalog I really do not have room to give you a detailed summary of the advantages of buying our Garden, Field and Flower Seed. But in this space I desire to give you a few of the more important factors. Our prices you will find to be as reasonable as anyone's; the quality is far better and the germination per cent is very high.

My twenty years' experience growing fruit and handling seed for one of the largest seed houses of the South is behind the seed we are offering to you. I have made the growing, handling and testing of seeds a life study and feel that when I tell you these are the best high-grade seeds obtainable you will believe me.

Your order, large or small, will receive prompt attention. What I want you to do is to try them out. We know that Happy to meet you.

(Signed) BILL QUINN. you will be pleased and come for more. Yours for better seeds,

\section{GARDEN AND VEGETABLE SEEDS}

A

GAIN this year we come forward with our "Heart of the Ozarks" Garden and Vegetable Seeds. Thousands of gardeners and customers were pleased last year and, this year with our stocks more complete than ever, there are going to be many most pleased and satisfied customers. Our stocks are fine, and taking into consideration the quality that we carry, the prices are exceedingly low. Remember, your satisfaction-or-your-money-back guarantee protects you.

\section{Our Positive Guarantee}

We exercise great care in growing, sorting and preparing all our seeds and fully guarantee them to be of high germination. They are sold to you under this Positive Guarantee, with the understanding that if they are not as represented and not fully satisfactory when you receive them, we will take them back and cheerfully refund your money. We do not want any customer to keep seed that they are not fully satisfied with. We are perfectly reliable and if any seeds are returned, the money for them will be refunded at once.

We further guarantee that if any of our Garden or Flower Seeds fail to grow on account of poor germination, we will replace them free of charge without quibbling or argument. We do not guarantee crop, for we cannot grow your crops or control weather conditions. This guarantee is absolutely binding on us and means just what it says.

\section{Asparagus}

Culture-As early in the spring as the soil will work up in good shape, sow seeds thinly in drills one foot apart. When the seedlings are two to four inches tall, thin them out to stand 2 or 3 inches apart in the row. Keep the rows free from weeds by frequent cultivation. The following spring prepare your permanent bed by applying plenty of well-rotted manure and some coarse salt which should be worked into the soil. Set your plants in shallow trenches, 6 inches apart in the row and do not cut the first year. Those who want asparagus more quickly should set out 2-year-old plants, obtainable from us. Prices on page 13.

Palmetto-A very early maturing and prolific variety, producing an abundance of early, large and deep green shoots of the best quality. Pkt. 5c, oz. $15 \mathrm{c}, 1 / 4 \mathrm{lb}, 40 \mathrm{c}$, postpaid.

Barr's Mammoth-The stocks are very large, sometimes an inch in diameter and retain their thickness completely up to the top and have long heads. They are quick growing, tender and of excellent quality. Pkt. 5c, oz. $15 \mathrm{c}, 1 / 4 \mathrm{Ib}$. $40 \mathrm{c}$, postpaid.

Columbian Mammoth White-This excellent variety furnishes shoots of exceptionally large size and of superior tenderness and flavor. The color is pure white until 4 or 6 inches above the surface. Pkt. 5 c, oz. 15c, 1/4 Ib. $40 \mathrm{c}$, postpaid.

\section{BEANS}

Culture-Beans are tender, and should not be planted until all danger from frost is past. No time is gained by planting them before the ground becomes warm. Drop the beans two or three inches apart, in rows standing eighteen inches or two feet apart; cultivate only when dry; draw the soil slightly toward them. They will make green beans in six to eight weeks sow every two weeks for a succession, if season. able up to September.

Please write for prices in larger quantities than quoted below.

Extra Early Red Valentine (Round Pod)-A valuable sort for home garden and shipping. Pods are usually ready to pick in about fortythree days from germination. Vine erect, pods medium length, curved, cylindrical, with crease in back; very fleshy; crisp and tender. Pkt. 10c, lb. 35 c, postpaid.

Burpee's Stringless Green Pod-Surpasses all other bush beans in crisp, tender qualities and fine flavor. For the home garden it is considered one of the best in its class. The pods are round, of good size, fleshy, strictly stringless, and continues bearing for a long time. Matures early. Seed brown. Pkt. 10c, Ib. 35c, postpaid.

Dwarf Black Wax-A very superior snapshort, ripening first among the earliest, and having the best characteristics. Pods round, yellowish white, fine flavor. Pkt. 10c, Ib. 35c, Dwarf Golden Wax-The pods are long, large brittle and entirely stringless, and of a beautiful rich golden wax color. Pkt. 10c, Ib. 35c 


\section{HERDY TREESAND PLANTS}

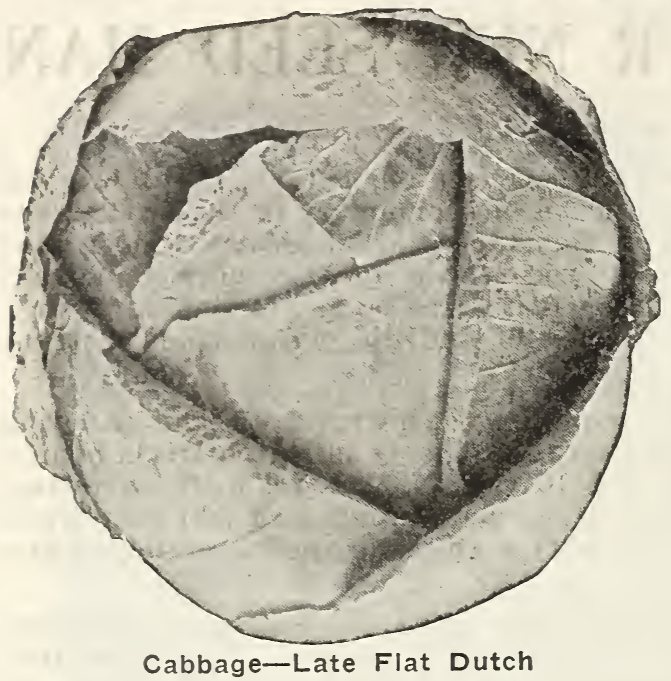

\section{Pole or Running Beans}

Kentucky Wonders-Vine vigorous, climbing well and very productive, bearing its pods in large clusters; pods green, very long, often reaching nine or ten inches; near round when roung and very crisp. Best pole bean for home garden and market. Pkt. $10 \mathrm{c}$, lb. $35 \mathrm{c}$, postpaid.

White Cornfield-Extremely early, very productive pods are borne in clusters of from four to six, broad, thick, solidly fleshy and stringless. Pkt. 10c, ib. 35c, postpaid.

\section{Pole Lima Beans}

Early Large White Lima-Productive, large, flat pods, rich and of finest flavor. The dry beans are white. Pkt. $10 \mathrm{c}$, Ib. $35 \mathrm{c}$, postpaid.

Henderson Bush Lima-Valuable on account of extreme earliness. Extremely productive, tender and delicious. The dry beans are small and white. Pkt. 10c, Ib. 35c, postpaid.

\section{BEETS}

Culture-Sow as soon as the land will permit, and for a general crop about the middle of April: sow in drills 15 inches apart and thin out to four inches; for winter use, sow the turnip varieties about July.

Egyptian Early Dark Red-A very early, dark blood red, medium size, tender and sweet: fine for kitchen garden. Pkt. $5 \mathrm{c}$, oz. $15 \mathrm{c}, 1 / 4 \mathrm{Ib} .35 \mathrm{c}$, lb. $\$ 1.00$, postpaid.

Early Blood Turnip-Here we have the old standby, the turnip beet, with its dark red color, well known to so many homesteads. Pkt. $5 c, 0 z, 15 c, 1 / 4$ lb. $35 c$, lb. $\$ 1.00$, postpaid.

Long Smooth Blood Red-When fully developed roots average 10 inches long by $3 \frac{1}{2}$ inches in diameter at the top. They are almost parsnip shaped, have firm, sweet, very dark flesh and make ideal pickles. Pkt. 5c, oz. $15 \mathrm{c}, 1 / 4 \mathrm{Ib}, 35 \mathrm{c}$, ib. $\$ 1.00$, postpaid.

Eclipse-An extra early variety, with round, smooth blood red roots. Matures very early and is popular both for market and home garden. Pkt. 5c, oz. $15 \mathrm{c}, 1 / 4$ lb. $35 \mathrm{c}$, Ib. $\$ 1.00$, postpaid.

\section{Cabbage}

Culture-Good drainage, plenty of manure on rich, heavy loam, and frequent cultivation are essential to success in cabbage-growing. For the early sorts sow the seeds in the fall and when the plants are a month old, transplant to cold-frames, setting them down to the first leaves. Sow also in January and February and transplant 2 to 3 feet apart in the rows, according to variety planted. For late variety, sow from the middle to the last of spring and transplant when 4 to 6 inches high.

All Seasons-One of the best of its class. Ready for the market only a few days later than the Early Summer and is much larger. The heads are firm, solid, and of good flavor. Pkt. 5c, oz. 25c, 1/4 lb. 90c, Ib. $\$ 3.00$, postpaid.

Early Jersey Wakefield-Market gardeners can find nothing better for an early cabbage. Heads somewhat pointed, extremely solid, superior quality. Pkt. $5 \mathrm{c}, 0 \mathrm{z}, 25 \mathrm{c}, 1 / 4 \mathrm{Ib} .90 \mathrm{c}, \mathrm{lb} . \$ 3.00$, postpaid.

Early Dwarf Flat Dutch-Has succeeded admirably on account of its ability to resist heat. It never flaws under the severest sun, and it produces very fine heads after the earliest sorts have disappeared. We recommend it highly. Pkt. 5c, oz. 25c, $1 / 4$ lb. 90c, lb. $\$ 3.00$, postpaid.

Late Flat Dutch-Grows to large size; flat, solid heads: a sure header, good keeper and shipper. Pkt. 5c, oz. 25c, 1/4 lb. 90c, Ib. $\$ 3.00$, postpaid.

Copenhagen Market-The heads are nearly round or slightly flattened, very hard and heavy. The growth is compact, there being few outside leaves, so the plants may be set close together. Copenhagen Market heads as soon as Jersey Wakefield cabbage. The most remarkable point about this cabbage is its uniformityevery plant under normal conditions will produce a good, solid head, and every head is as like another as two peas in a pod. The heads mature all at the same time so the crop can be cleaned up within a short time after the first heads mature. This is a very profitable cabbage to grow for market and an excellent early variety for the home garden. Pkt. 10c, oz. 35c, $1 / 4$ Ib. $\$ 1.00$, postpaid.

\section{Cantaloupes}

Culture-The same as watermelon, only the hills should be 5 or 6 feet apart, according to variety.

Rocky Ford-Very popular; flesh light color, sweet and delicate flavor. Pkt. $5 \mathrm{c}$, oz. $15 \mathrm{c}, 1 / 4 \mathrm{lb}$. $40 \mathrm{c}$, Ib. $\$ 1.25$, postpaid.

Salmon Tint Rocky Ford-The best cantaloupe for shipping. Flesh salmon pink. very sweet and grows a uniform size. Pkt. 5c, oz. $15 \mathrm{c}, 1 / 4 \mathrm{lb} .40 \mathrm{c}, \mathrm{Ib} . \$ 1.25$, postpaid.

\section{Carrots}

Culture-For early crops" sow in spring. as soon as ground can be worked, in drills 15 inches apart; cover seed one-half inch; thin plants to three or four inches in rows.

Danvers' Half Long-A rich orange led variety, very smooth and handsome. An excellent market variety. The most desirable main crop variety. Good keeper. Pkt. 5c, oz. $15 \mathrm{c}, 1 / 4 \mathrm{lb}$ 40c. Ib. $\$ 1.25$, postpaid.

Long Orange-The best late variety for general field culture. It keeps very well, and is therefore excellently adapted for winter use Pkt. 5c, oz. 15c, 1/4 Ib. 40c, lb. $\$ 1.25$, postpaid.

\section{Mangel-Wurzel}

Golden Giant-The largest of the yellow f'eshed mangels. Grows more than half above ground. Easy to harvest. An immense cropper. yielding 30 to 40 tons per acre. Splendid for feeding to poultry and livestock. Keeps well throughout the winter. Pkt. 5c, oz. 10c, $1 / 4 \mathrm{lb}$. 


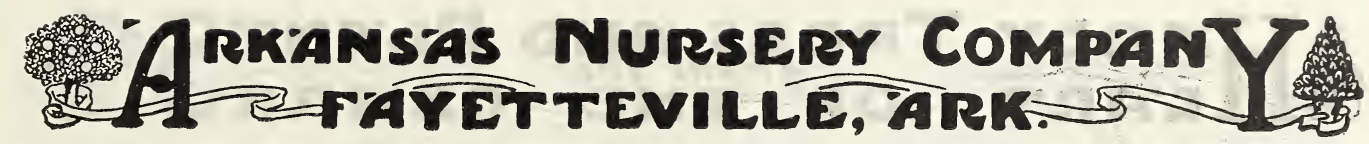

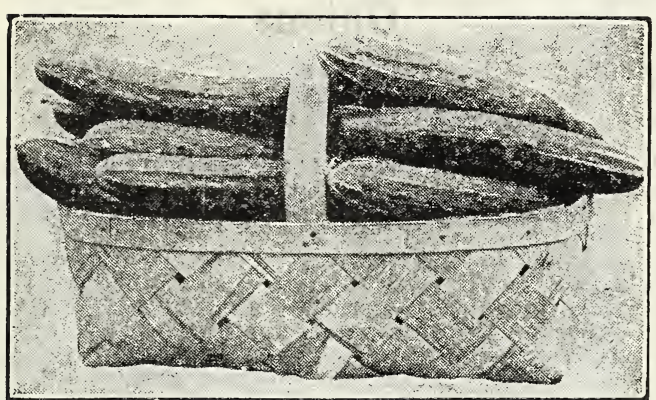

Cucumber-Long Green

\section{Cucumbers}

Culture-Cucumbers should not be planted until the ground gets warm, unless you are prepared to protect them during the cold storms. Plant in hills 6 feet apart each way, enrich the hills with a quantity of decomposed manure or packing house fertilizer; scatter 10 or 15 seeds on each hill, cover one inch deep and press the soil firmly over them; thin out to three or four plants to the hill; never allow any of the fruits to ripen on the vine, as they will cease setting fruit as soon as seed commences to mature.

Early White Splne-Valuable for the home garden as well as for early market. Under favorable conditions the fruits reach a length of 7 inches. They are borne early and in good numbers. Of uniform shape, almost cylindrical and fairly well covered with small white spines. Pkt. 5c, oz. 15c, 1/4 Ib. 40c, lb. $\$ 1.25$, postpaid.

Long Green-Very productive; fruits quite long, averaging 10 to 12 inches in length. Very popular both as a slicer and for pickles. One of the best general purpose cucumbers. Pkt. 5c, oz. $15 \mathrm{c}, 1 / 4$ Ib. $40 \mathrm{c}$, Ib. $\$ 1.25$, postpaid.

Short Green Pickling-This variety is known as Early Fame, and is an excellent sort, both for table use and for pickling. Comes into condition for 'use a little later than Early Cluster. Pkt. 5c, oz. 15c, $1 / 4$ Ib. $40 \mathrm{c}$, Ib. $\$ 1.25$, postpaid.

Early Cluster-Vine vigorous, producing the bulk of the crop near the root and in clusters. Fruit short, "with uniformly thick end, dark green, but paler at blossom end. A very productive sort. Pkt. $5 \mathrm{c}$, oz. $15 \mathrm{c}, 1 / 4 \mathrm{Ib} .40 \mathrm{c}, \mathrm{Ib} . \$ 1.25$, postpaid.

Write for Prices in Larger Quantities.

\section{Egg Plant}

Culture-The seed should be planted in a hot bed or box in the house, care being taken that the plants have an even, continuous heat. They do not respond to a setback very readily. Transplant only vigorous plants when the weather is warm.

New York Improved Spineless-Our selected strain of this popular sort has no superior among its kind. It is the most beautiful, as Well as edible of the many varieties of egg plant. A well grown specimen never fails to take the premium at the fair. It is absolutely spineless. Pkt. 10c, oz. 50c, $1 / 4$ lb. $\$ 2.00$, postpaid.

\section{Gentlemen:}

Oden, Arkansas, March 28, 1921.

The trees you sent to replace the two that were dead received, and I have them planted.

The other trees have all put out leaves and look fine and I thank you for the premium peach. I am very proud of it, as well as my other trees.

\section{Garden Peas}

Culture-Sow in earliest spring and make successional plantings every ten days until June 1. In the latter part of August sow early peas for an autumn crop. Drill 1 to 2 inches deep in rows $2 \frac{1}{2}$ to 4 feet apart. In the field use no sticks. In garden culture sow in double rows 10 inches apart, and use supports for the tall growing varieties.

First of All-This is a reliable early cropper of the hardy smooth seed and variety. Not quite as early as Alaska, but great improvement over its parent, old Philadelphia. Extra early. Pkt. $10 \mathrm{c}$, lb. $35 \mathrm{c}$, postpaid.

Alaska-A variety of remarkable earliness and hardiness. It is a good yielder and produces pods of good size and dark green color, which are well filled with round smooth peas of splendid flavor. Pkt. 10c, Ib. 35c, postpaid.

Telephone-A vigorous grower; extra large well filled pods. Pkt. 10c, lb. 35c, postpaid.

White Marrowfat-Grow 4 to 5 feet in height: Pods large, round, light green and well filled. Excellent for summer crop. Pkt. 10c, Ib. 35c, postpaid.

Write for Prices in Larger Quantities.

\section{Kale}

Siberian-Popular boiling-greens for fall, winter, and spring. Very popular in the South. Quite hardy and deserves more general cultivation in the North. Pkt. 5c, 0z. 20c, 1/4 Ib. 60c, Ib. $\$ 1.50$, postpaid.

\section{Mustard}

Culture-For salad and greens, sow broadcast early in spring, also in fall.

Southern Giant Curled-Highly esteemed for salads, particularly in the South. The leaves are twice the size of the ordinary white mustard; flavor sweet and pungent. Pkt. $5 \mathrm{c}$, oz. $10 \mathrm{c}, 1 / 4$ lb. 30 c, lb. $\$ 1.00$, postpaid.

Large Smooth Leaved-Has a large, fleshy leaf. The flavor is mild and it is quite slow in sending up its seed stock, remaining a long time fit for table use. Pkt. $5 \mathrm{c}$, oz. $10,1 / 4$ lb. $30 \mathrm{c}$, Ib. $\$ 1.00$, postpaid.

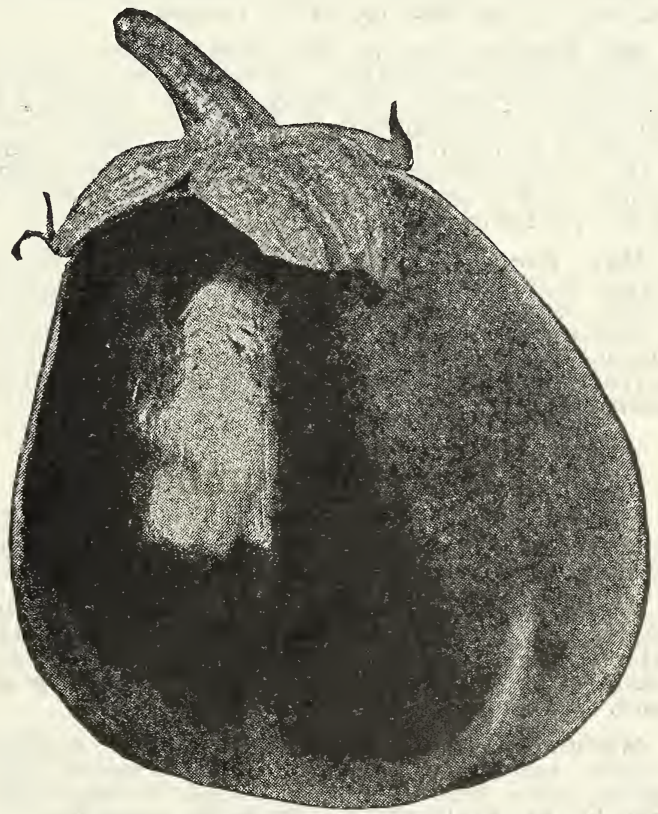

Egg Plant-New York Spineless 


\section{MHARDY TREESAND PLANTS}

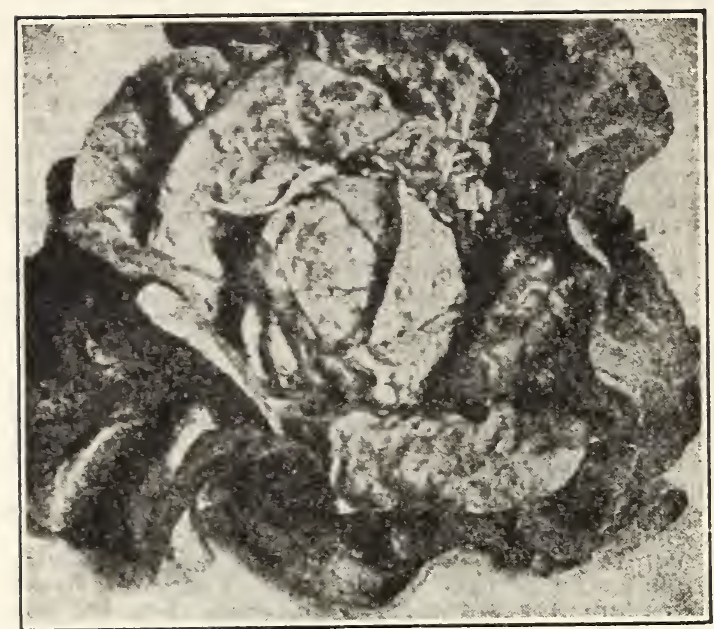

Lettuce-Big Boston

\section{Lettuce}

Culture-Lettuce thrives best in light, very rich, moist soil, but does well in common garden soil enriched with rotten manure. For first crop sow in gentle heat in February, and transplant to ten inches apart. It may be sown thickly and cut when plants are very young. For a summer supply sow thinly in shallow drills in a cool, partially shaded place, in rich soil, and thin to a foot apart.

Early Curled Simpson-Early; forms a compact mass of tender leaves of a yellowish green color. Pkt. $5 \mathrm{c}$, oz. $15 \mathrm{c}, 1 / 4 \mathrm{lb} .40 \mathrm{c}$, Ib. $\$ 1.25$, postpaid.

Black Seeded Simpson-A superior variety: large, light colored heads. Pkt. $5 \mathrm{c}$, oz. $15 \mathrm{c}, 1 / 4 \mathrm{Ib}$ 40 c, lb. $\$ 1.25$, postpaid.

Prize Head-Plant large, deep green, so washed with red as often to appear more red than green, forming a head of a dense mass of leaves rather than one like a cabbage. Pkt. $5 \mathrm{c}$, oz. $15 \mathrm{c}, 1 / 4$ Ib. $40 \mathrm{c}, \mathrm{Ib}$. $\$ 1.25$, postpaid.

Big Boston-One of the most popular of the old standard varieties; desirable for forcing. Especially valuable for early outdoor planting or for late fall planting as it will endure cold weather conditions better than any other variety. Large compact heads of light green leaves, tender and crisp. Pkt. 5c, oz, $15 \mathrm{c}, 1 / 4 \mathrm{lb} .40 \mathrm{c}, \mathrm{lb}$. $\$ 1.25$, postpaid.

May King-Of quick growth and produces large, handsome heads with few outside leaves. Color light green, outer leaves folding closely, producing round, solid heads 6 to 7 inches in diameter. Splendid for market gardeners or private use. Pkt. $5 \mathrm{c}$, oz. $15 \mathrm{c}, 1 / 4$ Ib. $40 \mathrm{c}, \mathrm{Ib} . \$ 1.25$, postpald.

\section{Okra or Gumbo}

Culture-When the ground has become warm, sow thickly in drills 2 feet apart, and when large enough, thin out to 8 inches apart in the rows.

White Velvet-The plant is of medium height, bearing a large crop of white, smooth pods, which retain their tenderness until nearly full sized. Pkt. $5 c, 0 z .10 \mathrm{c}, 1 / 4$ lb. $35 \mathrm{c}, \mathrm{Ib} . \$ 1.00$, post. paid.

Mammoth Long Pod-Plant is of medium height, producing beautiful long, slender, deep green pods, which remain tender a long time. Pkt. 5c, oz. 10, $1 / 4$ Ib. 35 c, Ib. $\$ 1.00$, postpaid.

\section{Onions}

Culture-Onions are raised in two ways, from seed and from sets. Seed sown in early spring produces ripe onions in the fall, while sets planted at the same time make green "bunching" onions in a few weeks and dry ripe onions in July or earlier. Sets may be put out in the fall and will produce green onions much earlier than when set out in the spring. To Iaise good onions from seed the land must be rich and in fine condition. Sow the seed as early as possible in rows 14 inches apart. Weed as soon as the onions appear and keep well cultivated all through the season. Seed may also be sown in a hotbed or greenhouse in February or March and the onions transplanted to the open ground when warm enough. The finest onions are raised in this way.

Large Red Wethersfield - The old standard sort; best for main crop. Large deep red, thick nearly round, fine grained, pleasant flavored and productive. Ripens in September and keeps well. Pkt. $5 c, 0 z .20 c, 1 / 4$ lb. $60 c$, Ib. $\$ 2.00$, post. paid.

Large Red Globe-Medium early; grows to a large size; skin deep red, flesh fine grained, mild and tender. A good yielder. Pkt. 5c, oz. 20c, $1 / 4$ Ib. 60 c, Ib. $\$ 2.00$, postpaid.

Improved Yellow Giant-Succeeds everywhere, whether grown for home use or marketing it gives universal satisfaction, yielding onions often 14 inches around. Easily grown. Pkt. 5c, oz. 20 c, $1 / 4$ lb. 60 c, Ib. $\$ 2.00$, postpaid.

White Silver Skin-Matures early; rather flat in shape, mild flavor; excellent for winter; very much esteemed for pickling when small. Pkt. $10 \mathrm{c}, 0 z$. $30 \mathrm{c}, 1 / 4 \mathrm{Ib}$. $90 \mathrm{c}, \mathrm{Ib}$. $\$ 3.25$, postpaid.

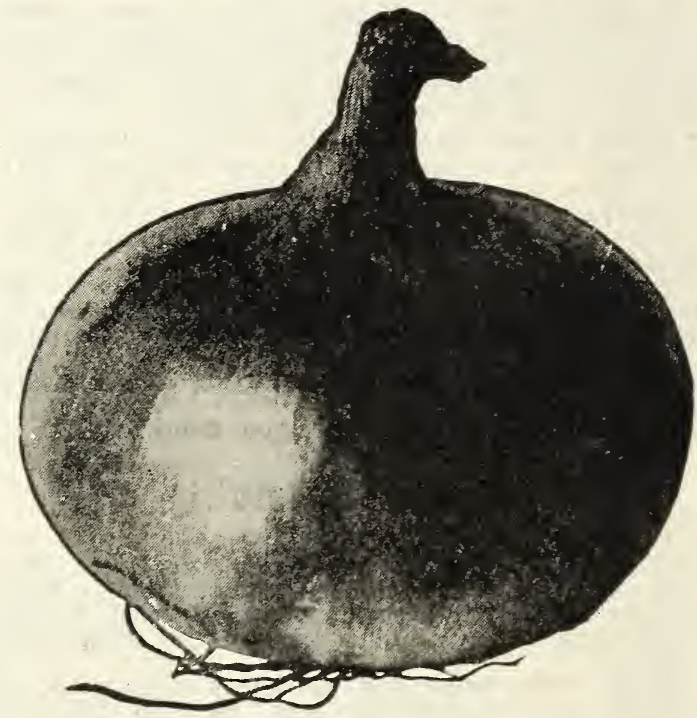

Onion-Improved Yellow Giant

335 South 10th.

Gatesville, Texas, March 7, 1921.

have received my trees and vines in first-class condition and $\mathrm{I}$ am pleased. The roots are still damp and the buds swelling. I wish to say you may expect some business from $m e$ in the future.

$$
\text { L. A. THOMPSON. }
$$

\section{Peoria, Okla., Feb. 26, 1921.}

1 received the Strawberry Plants on the 23d. They were in good condition for plant. ing. FRANK STAYE. 


\section{Arkansas Nursery COMPANY}

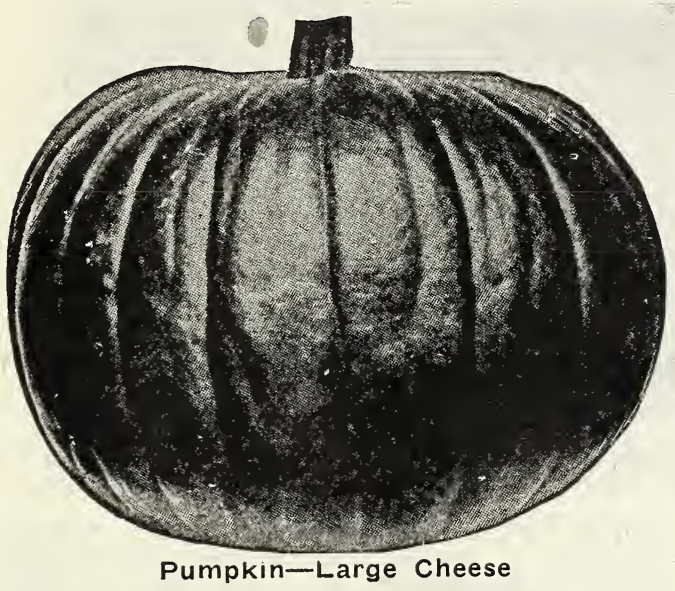

Parsnips

Culture-Sow in early spring, in rows 2 to 3 feet apart; thin to 4 to 6 inches in the row. A packet will sow about 40 feet of drill, an ounce about 200 feet, 4 to 5 pounds per acre in drills $21 / 2$ feet apart. Cover the seed $1 / 2$ inch. Ready to use in about 80 days or may be stored in the cellar for winter use or left in the ground all winter and dug when weather permits, or leave in the ground for spring use.

Hollow Crown-The best for table use; a vegetable of merit easily raised and of great productiveness. Pkt. $5 \mathrm{c}$, oz. $15 \mathrm{c}, 1 / 4$ Ib. $40 \mathrm{c}$, Ib. $\$ 1.35$, postpaid.

\section{Peppers}

Culture-Sow early in hotbed, and when soil has become warm, plant out in rows 2 feet apart, and 18 inches in rows.

Sweet Bell or Bullnose-A very large pepper of square shape, mild, thick and hard. Suitable for stuffing and for mixing pickles. It is less pungent than other sorts, and notwithstanding its size, it is one of the earliest. Pkt. 10c, oz. $50 \mathrm{c}, 1 / 4$ lb. $\$ 1.50$, postpaid.

New Chinese Giant-Is the largest mild pepper in cultivation; on account of its earliness, productiveness and large size, truckers have found this a most profitable variety. Flesh unusually thick, mild and sweet. Pkt. 10c, oz. 60c, 1/4 lb. $\$ 1.75$, postpaid.

Large Red Cayenne-Bright red fruits, 3 to 4 inches long, very hot. Pkt. $10 \mathrm{c}$, oz. $50 \mathrm{c}, 1 / 4 \mathrm{lb}$. $\$ 1.50$, postpaid.

\section{Pe-Tsai}

Chinese or Celery Cabbage-A new vegetable from China, that is attracting much attention. By tying up the large outer leaves it blanches like celery. As a salad it rivals the finest lettuce, or cooked like cabbage or spinach, it makes splendid greens. For main crop sow the seed last of August, and transplant a foot apart when large enough. Pkt. 5c, oz. 30c, 1/4 Ib. $\$ 1.00$, postpaid.

\section{Pumpkins}

Kentucky Field-Large round, flattened; hardy and productive. One to two feet in diameter. It has thick flesh of extra fine quality and is a splendid sort for canning, family and market use, and is used largely for stock feeding. Pkt. $5 c$, oz. $10 \mathrm{c}, 1 / 4$ lb. $30 \mathrm{c}$, Ib. $90 \mathrm{c}$, postpaid.

Large Cheese-Best for canning; has heavy, thick, sweet meat; large round flattened variety with creamy-buff skin. An excellent keeper and very productive; good quality. Pkt. $5 \mathrm{c}$, oz. $10 \mathrm{c}$, $1 / 4$ ib. $35 \mathrm{c}$, Ib. $\$ 1.00$, postpaid.

\section{Radishes}

Culture-The soil for radishes should be light, rich and well pulverized, as their mild and crisp qualities depend much on their rapid growth. For very early use, sow in mild hotbeds in January, and in open ground as soon as the ground can be worked; for succession, sow at intervals of ten or twelve days; they also do well sown in the fall.

Long White Lady Finger-Beautiful in shape; skin and flesh are pure white, very crisp and tender; a most rapid grower and long standing. Pkt. 5c, oz. 15c, 1/4 Ib. 40c, lb. $\$ 1.25$, postpaid.

Early Scarlet Turnip-A small, round, red turnip-shaped radish with a small top and of quick growth. An early variety of rich color, crisp and tender. Pkt. 5c, oz. 15, 1/4 lb. 40c, Ib. $\$ 1.25$, postpaid.

Long Scarlet-It grows 6 to 7 inches long half out of the ground. It is very brittle and crisp, and quick growth; color bright scarlet. Pkt. $5 c$, oz. $15 c, 1 / 4$ Ib. 40 c, Ib. $\$ 1.25$, postpaid.

Early White Turnip-Very handsome; of quick growth; sweet, juicy and tender; skin ivory white, flesh pure white. Pkt. $5 c$, oz. $15 \mathrm{c}, 1 / 4 \mathrm{lb}$. $40 \mathrm{c}$, Ib. $\$ 1.25$, postpaid.

Early Scarlet Turnip, White Tip-A most popular and attractive variety, a great favorite in many large markets. The radish is bright scarlet, with white tip and of a beautiful shape; flesh white, crisp and finely flavored. Pkt. 5c, oz. $15 \mathrm{c}, 1 / 4$ Ib. $40 \mathrm{c}, \mathrm{lb} . \$ 1.25$, postpaid.

Long White Icicle-The finest white radish grown. Long slender root which remains tender and crisp until grown. Matures early, has small top which permits close planting Considered by many to be the finest radish. Plant every 10 days for succession. Pkt. $5 \mathrm{c}$, oz. $15 \mathrm{c}, 1 / 4 \mathrm{lb}$. 40 c, Ib. $\$ 1.25$, postpaid.

\section{Rhubarb or Pie Plant}

Rhubarb is vigorous and productive. The leaf stalks are very numerous, the longer ones being from 15 to 20 inches in length, and fully 11 inches wide. The whole plant is nearly $51 / 2$ feet in diameter, while the leaves, exclusive of the flower stalks, are about $2 \frac{1}{2}$ feet in height. Rhubarb is very highly esteemed for use in pies, tarts, jelly and marmalade, and large quantities are sold in all markets every year. It is the first vegetable of the season and no garden should be without it. Pkt. 5c, oz. 20c, 1/4 ib. 75 c, postpaid.

Culture-Sow the seed in cold frame in the spring and as soon as the plants are large enough transplant into rows 5 feet apart each way, and each spring work into the soil a liberal supply of decomposed stable manure. One ounce of seed will sow 75 feet of row.

Rhubarb Roots-Rhubarb roots are set out and cultivated as the above, and this method gives edible rhubarb in a very short time.

\section{Spinach}

Cultivated very extensively for "greens." A profitable crop for market. Select a rich welldrained soil, highly manured. For a succession sow early in April and again in May in drills 1 foot apart and 1 inch deep, properly thinning out when the plants are an inch in the leaf. For early spring use sow early in autumn and protect the plants with a light covering of leaves or straw.

Bloomsdale (Savoy)-The earliest of all and one of the best; the leaves are numerous, curled and wrinkled. Pkt. $5 \mathrm{c}, 0 \mathrm{z}, 10 \mathrm{c}, 1 / 4 \mathrm{lb}, 25 \mathrm{c}, \mathrm{Ib}$ 


\section{MARDY TREES AND PLANTS}

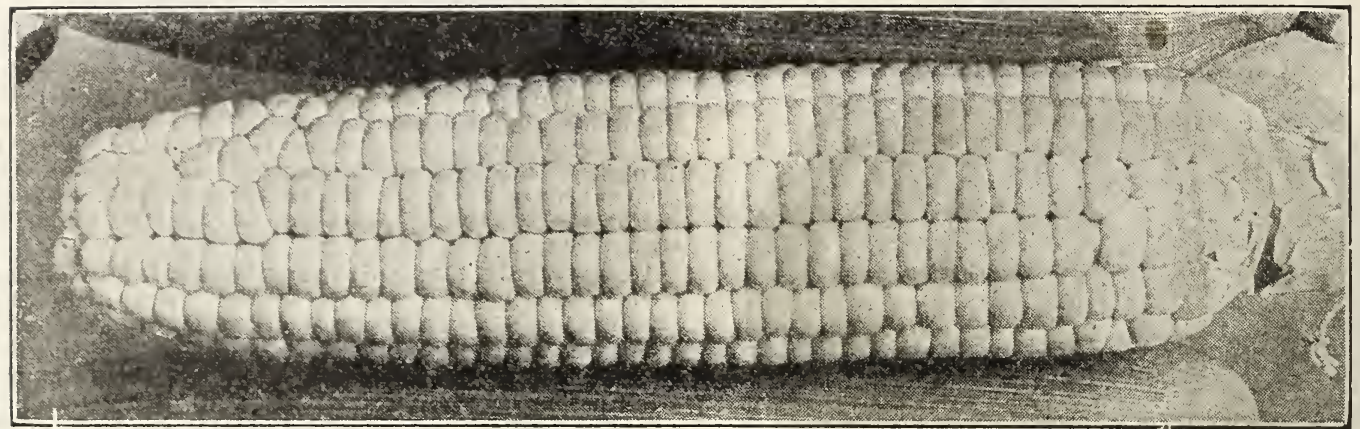

\section{Squashes}

Culture-Squashes require a warm, fertile soil of sandy nature for best growth. Summer squashes grow mostly in compact bush form: hills for these should be about 4 feet apart; for long, trailing fall and winter varieties hills should be $\delta$ to 12 feet apart each way. If ground is not very rich, two or three shovelfuls of well-rotted manure should be worked into each hill. Put 8 to 10 seeds in each hill, about one inch deep. When danger from bugs is over, thin from 3 to 4 of the strongest plants.

Light White Bush, or Patty Pan-The best early variety. The plants are of true bush form and produce fruit very early in the season. Largely grown in the South for shipment to Northern markets. Pkt. $5 \mathrm{c}$, oz. $15 \mathrm{c}, 1 / 4 \mathrm{lb} .50 \mathrm{c}$, postpaid.

Yellow Summer Crookneck-The plants are very productive and early-bearing; skin of fruit very thickly warted and of orange yellow color Pkt. 5c, oz. $15 \mathrm{c}, 1 / 4$ lb. 50c, postpaid.

Lawton, Okla., March 22, 1921.

I received my order of fruit trees and berry vines. They came to my hand in perfect good condition. If they live and grow well, which I think they will, I will surely re. member you next season for another order. Thanking you for the nice premium.

MRS. J. A. MORETTI.

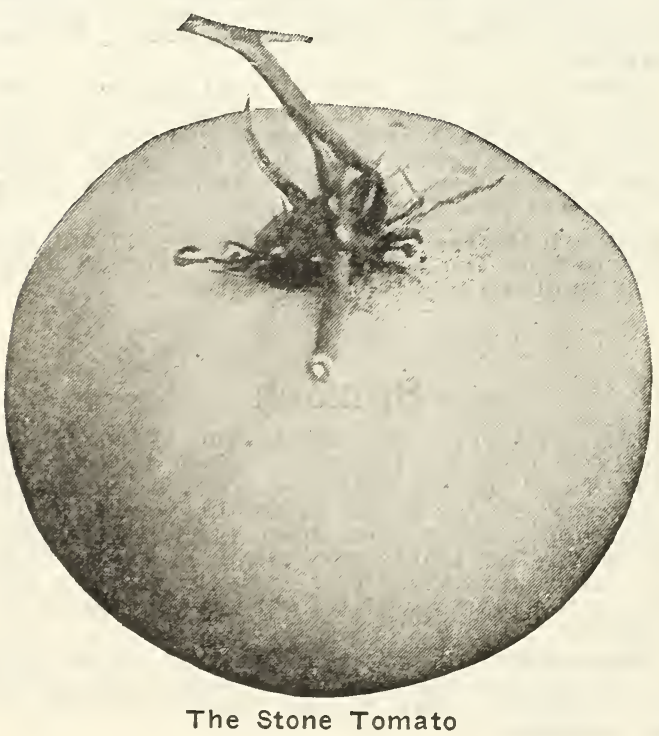

\section{Sweet Corn}

Culture-Plant in hills 3 feet apart; leave 2 or 3 plants to the hill; where ground is strong. Country Gentlemen or Shoe-Peg-A wellknown medium-early sired. Very productive. Market gardeners who supply hotels and highclass restaurants depend on this for main crop. Pkt. 10c, Ib. 35c, postpaid.

Golden Bantum-A very early sweet corn with golden-yellow grains. Generally considered the sweetest and tenderest variety in existence. Probably more extensively grown than any other early variety. Ears 6 to 7 inches long. Pkt 10c, lb. 35 c, postpaid.

Stowell's Evergreen-The standard main crop variety, excelling all other late sorts in productiveness and fine quality. The most popular canning variety. Our stock was grown for us by one of the most careful growers. Pkt. 10c, Ib. $35 \mathrm{c}$, postpaid.

\section{Swiss Chard of Spinach Beet}

Swlss Chard-Grown exclusively for the numerous fleshy tender leaves and leaf stalks. The mid-rib is cooked and served like asparagus, the leaves the same as spinach. The plants sometimes grow to a height of two feet. Swiss Chard should have a prominent place in all gardens. Valuable for greens for chickens by cutting the stem and the leaf. Pkt. 5c, oz. 15c, $1 / 4$ Ib. $35 \mathrm{c}$, Ib. $\$ 1.00$, postpaid.

\section{Tomatoes}

Culture-For early crops sow in January and February in pots and boxes, and place near a window or in spent mild hotbeds; keep well watered; when plants are three inches high transplant into another frame, to remain until ready for planting out; this makes them strong and stocky. If you wish the first fruits that set to ripen quickly, pinch off the tops of vine and later fruit shoots; all vining varieties ought to be staked and tied up.

Globe-One of the newer sort of unquestionable merit. In season of maturity it closely rivals June Pink, perfecting its first fruits within a week after that recognized standard for earliness. But the fruits are very much handsomer, being nearly round, with a skin free of blemish, filled with solid meat. Globe is unusually prolific. Fruits are borne in clusters of 4 to 6 and frequently 5 clusters are carried by well developed plants. Of finest table quality. Pkt. $5 \mathrm{c}$, oz. $30 \mathrm{c}, 1 / 4 \mathrm{lb} . \$ 1.00$, post. paid.

Ponderosa-The fruit ripens early and bears well until very late; very solid, almost seedless; of good sub-acid flavor and of immense size, frequently weighing considerably more than two pourds. Somewhat scattered on the vine, and a small percentage are rather rough. Our strain, however, is now producing a much smoother fruit than when first introduced. Good tomato for home use; splendid slicer. Pkt. 10c, oz. $45 \mathrm{c}$, 


\section{AKansas Nursery COMPANT}

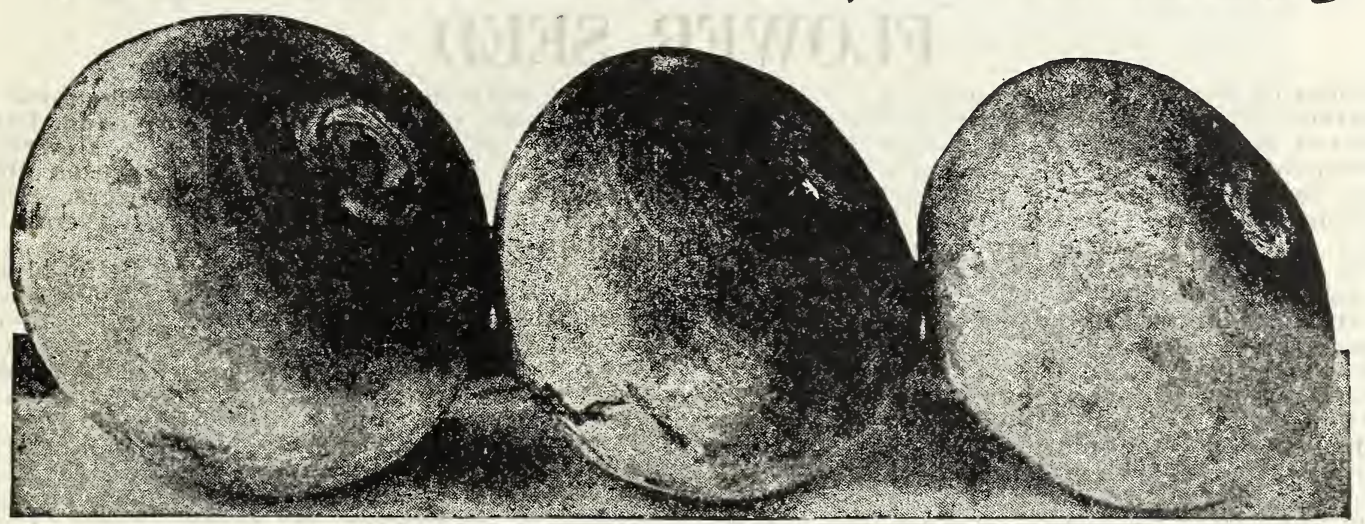

Turnip-Purple Top White Globe

Dwarf Champion-A purplish pink variety, forming a strong, erect, bushy plant. Often sold as a tree tomato. Fruit smooth, medium sized, solid and good flavor. Desirable for forcing, as it can be planted close to the grass and more closely on the bench than the tallgrowing kinds. Pkt. 5c, oz. 30c, $1 / 4$ lb. $\$ 1.00$, postpaid.

Livingston's Beauty (Color Purple)-One of the oldest and still very popular in the great shipping centers for reason of its being always exceptionally smooth and uniform in size. It is one of the best main crop sorts. Pkt. 5c, oz. 30c, $1 / 4$ Ib. $\$ 1.00$, postpaid.

Stone-The standard bright red main crop sort throughout the country. Solid as a rock, heavy as a stone; as sweet as any tomato can be; these are a few of the points that put Stone in a class of its own. A great favorite with canners on account of its solidity and the great crops which it yields. Always smooth and of good size. Pkt. 5c, oz. 30c, $1 / 4$ lb. $\$ 1.00$, post. paid.

\section{Turnips}

Culture-For summer use sow early in spring in light, rich or new soil, in drills $11 / 2$ to feet apart according to size of the variety and cover one-half inch deep, or sow broadcast, but in either case be sure to have the ground rich and freshly stirred. Thin early and keep free from weeds so that the young plants will not be checked in growth. Any overcrowding will result in rough and poorly flavored roots. It is important to get the spring and summer crop started very early so that the turnips may have time to grow to sufficient size before hot weather causes them to become tough and bitter.

Extra Early White Milan-The earliest turnip. Tops very small, distinctly strapleaved, and growing very erect and compact. Bulbs form earliest of any sort. The clean, white roots are smooth, flat, symmetrical and handsome in appearance. The flesh is white, tender and sweet. Pkt. 10c, oz. 20c, 1/4 lb. 65c, Ib. $\$ 1.75$, postpaid.

Early Flat White Dutch-A quick growing, medium sized root for early spring or fall planting. The skin and flesh are both pure white, the latter being quite tender and sweet. The turnip is flat, with a fine tapering root, the leaf is strap shaped. For home use there is no turnip that we would rather recommend. Pkt. $5 \mathrm{c}$ oz. $10 \mathrm{c}, 1 / 4 \mathrm{Ib} .25 \mathrm{c}$, Ib. $75 \mathrm{c}$, postpaid.

Purple Top Strap Leaved-The most widely cultivated and best known variety. Used largely for sowing broadcast among corn and potatoes It is round and flat, white on the bottom and reddish purple above ground, and a very quick grower. It is esteemed as a fine table variety. Pkt. 5c, oz. 10c, $1 / 4$ lb. 25c, lb. 75 c, postpaid.
Purple Top White Globe-Of a perfect globe shape, almost six inches in diameter with smooth, white skin; flesh pure white, firm and crisp, and of quick growth. A good keeper and is fine for market. Pkt. 5c, oz. 10c, 1/4 Ib. 25c, Ib. $75 \mathrm{c}$, postpaid.

Seven Top-Does not produce a good root, but is extensively grown in the South for the tops, which are used as greens. Very hardy and will grow all winter. Pkt. $5 \mathrm{c}$, oz. $10 \mathrm{c}, 1 / 4$ ib. $25 \mathrm{c}, 1 \mathrm{~b}$. $75 c$, postpaid.

\section{Watermelons}

Culture-Plant in hills 8 or 10 feet apart, dropping ten seeds to the hill; thin out to three plants to the hill, cultivate until the vines cover the ground, and pinch the ends of the early shoots to induce early fruiting.

Tom Watson-In the last few years this melon has become immensely popular. The average size fruit of this variety reaches the size of 24 to 28 inches long and 12 to 14 inches in diameter. It has a dark mottled green rind, thin, but tough enough to stand shipping long distances. For the home or for the market garden or for shipping it is a money-maker for the growers. The seed we offer is of the very best strain. Pkt. 5c, oz. $15 \mathrm{c}, 1 / 4 \mathrm{lb} .40 \mathrm{c}, \mathrm{lb} . \$ 1.25$, postpaid.

Halbert's Honey-One of the finest melons for the home garden, of superb luscious quality; medium large, oval; dark glossy green; flesh bright crimson. Very tender and sweet. Pkt. 5c, oz. 15c, I/4 Ib. 40c, Ib. $\$ 1.25$, postpaid.

Improved Kleckley Sweets-Special strain of this grand market gardener's melon. Large, oblong, 26 inches in length by 10 to 12 inches in diameter, dark green, flesh bright scarlet, rind only about half an incl thick. Extremely sweet and sugary and of such tendermess that it leaves no strings or pulp whatever. It is a melon for home use, but ships very well. Undoubtedly one of the best melons of today. Pkt. $5 c$, oz. $15 \mathrm{c}, 1 / 4$ Ib. $40 \mathrm{c}, \mathrm{Ib}$. $\$ 1.25$, postpaid.

Denver, Colo., March 20, 1921.

I received the Strawberry Plants I ordered in fine condition, and planted them the same day. Will recommend your nursery to any. one I know wanting nursery stock.

Stock Yard Sta. MRS. JOHN GREANS.

R. 2, Box 64 .

R. A, Liberal, Kas.

Gentlemen:

Wetmore, Texas, March 20, 1921.

1 received my order in nice condition. The Strawberry Plants are nice. Thanking you for your kindness, I am Yours truly,

MRS. ELLIS Á. GRIFFIN 


\section{Hard TreEs AND PlantS FLOWER SEED}

Prices on flower seed are postpaid.

Asters-These universally grown and greatly admired flowers have undergone a great improvement in varieties of late years. Our mixtures contain a number of the best strains and furnish a choice selection of cut flowers in many shades of color. Sow indoors or under glass and at different times for a succession of bloom. Pkt. 10c.

Chrysanthemum (Mixed)-These are not the large varieties grown and handled by florists. The annual varieties we offer are of many beautiful colors and similar to large daisies. If the shoots are nipped off when plants are young they become more bushy. For early bloom start indoors, or sow where plants are to bloom. Pkt. 10c.

Cosmos (Mixed)-When many of the garden flowers are through blooming the Cosmos starts in. Tall, graceful, bushy, with feathery foliage. Plants producing a great variety of daisylike flowers in many colors. Sow outdoors after danger of frost is past. Pkt. $5 \mathrm{c}$.

Shasta Daisy-The plant grows fast and increases rapidly. It is a fine bloomer. The flowers measure 2 to 3 inches across and are borne on long stems. They have two rows of long, broad white petals and a yellow center. Pkt. 10c.

Hollyhocks-A favorite with everyone. Tall and stately and always handsome. Most beautiful when seen in groups or long rows with a background of evergreens or shrubbery. Pkt. 10c.

Hellotrope (Mixed)-An old fashioned favorite plant noted for the intense fragrance of the violet colored flowers. If sown early indoors or in hotbeds, large, stocky plants can be produced, which will bloom all season outdoors. Easy to grow from seed. Heliotropes are good pot plants for the house during winter. Pkt. 10c. Larkspur, Dwarf Bedding-These lovely annals are quite hardy. The blooms are exceedingly handsome and most suitable for beds. Height, 1 foot. Pkt. $5 \mathrm{c}$.

Marigold-One of those appreciated "sure to grow and bloom" garden flowers. Sow in spring where plants are to stand or in boxes and transplant. Grows about 2 feet tall and thrives best in a sandy loam. Pkt. 5c.

\section{Nasturtiums}

Glant Flowering Dwarf Mixed-These grand new bedding Nasturtiums are brilliant in the extreme. They produce in wonderful abundance large flowers of the most gorgeous hues. The colors are very intense, making a sharp diversity of color not to be found in common mixtures. The plants are strong and vigorous, growing very quickly and producing erect, symmetrical bushes, with foliage from light green to deep blue green. Pkt. 5c, oz. 15c, $1 / 4$ ib. $40 \mathrm{c}$.

Tall Glant Flowering Mixed-A wonderful diversity of rich colors and new and striking combinations are found in this unequaled mixture. A row in full bloom is truly gorgeous beyond description, containing as it does every shade and tint of yellow, rose, scarlet, carmine, orange, lemon, bronze, violet, purple, maroon, ruby, cream and pink, both in solid colors and mottled and striped in many showy and exquisite ways. Pkt. 5c, oz. 15c, $1 / 4 \mathrm{lb} .40 \mathrm{c}$.

Pansy (Mixed)-Pansies are familiar to most everyone and few are planting a garden without pansies. During recent years there has been a great improvement in size and color of flowers and in length and strength of nower stems. Pkt. 10c.

Petunia (Mixed)-For vases, urns and window boxes, there is hardly a plant that can compare with petunias. Continues hlooming in a multitude of colors and of drooping habit it is one of the most effective of flowering plants, far superior for these purposes than geraniums. Single and double flowers. Best started in boxes or under glass. Plenty of moisture and rich soil. Pkt. $10 \mathrm{c}$.

Phlox (Mixed)-These beautiful little plants furnish a diversity of color and shades and when sown they make flower garden themselves. Good soil and plenty of water in a sunny location are all they require for constant bloom. Sow out of doors or for early bloom in boxes or under glass. Pkt. $5 \mathrm{c}$.

Poppy (Mixed)-These wonderful plants with their multitude of colors put life into the garden before most any other plants have started. Against a background of green foliage, there are hardly any plants presenting such an intense array or veritable riot of colors. Thrive best in a sandy loam and should be sown very early" and only in sunny exposure. Sow several times for succession. Pkt. $5 c$.

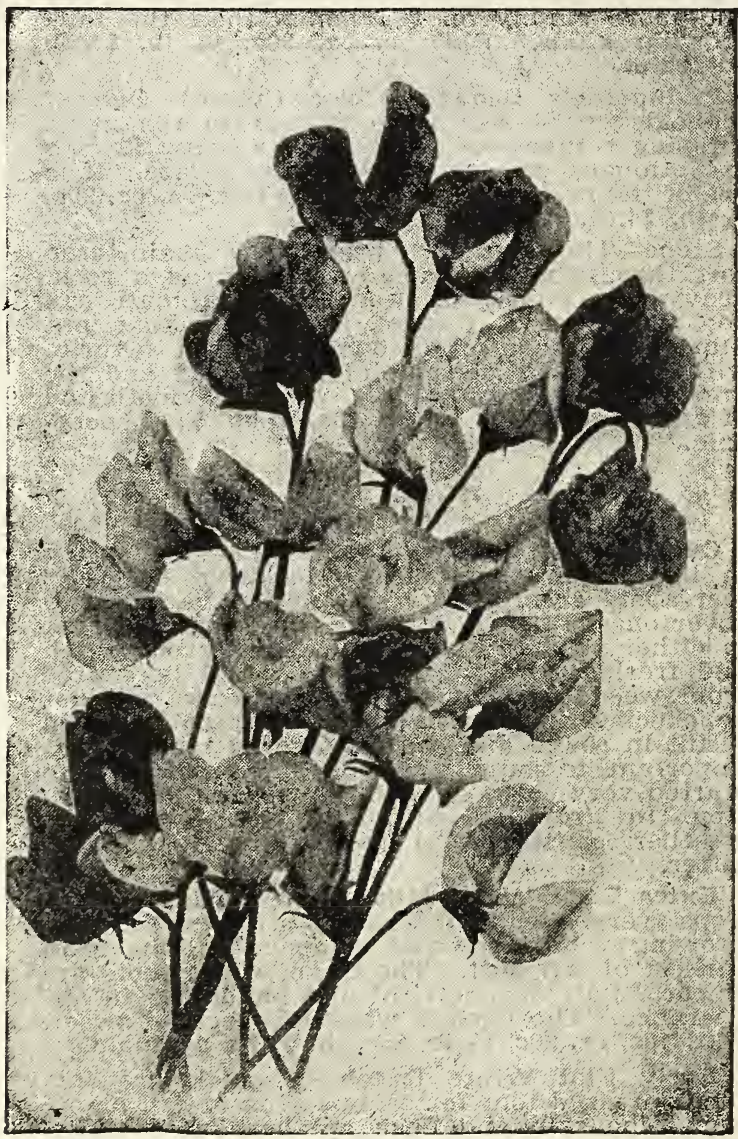

\section{Sweet Peas.}

Sweet Peas-Choice-Sweet Peas will grow and blossom in any good garden soil. For best success sow early, as early as the ground can be worked in the spring. Regardless of the weather sow early, in March or early April, in trenches 4 inches deep; cover about 1 inch with soil, and fill the trench as plants grow. Set the support early and hoe often. The Spencer mixture which we offer contains a beautiful mixture of colors and of large, gracefully frilled blossoms. Pkt. 5c, oz, $15 \mathrm{c}, 1 / 4$ lb. $40 \mathrm{c}$. 


\section{G ARKANSAS Nursery COMPANY}

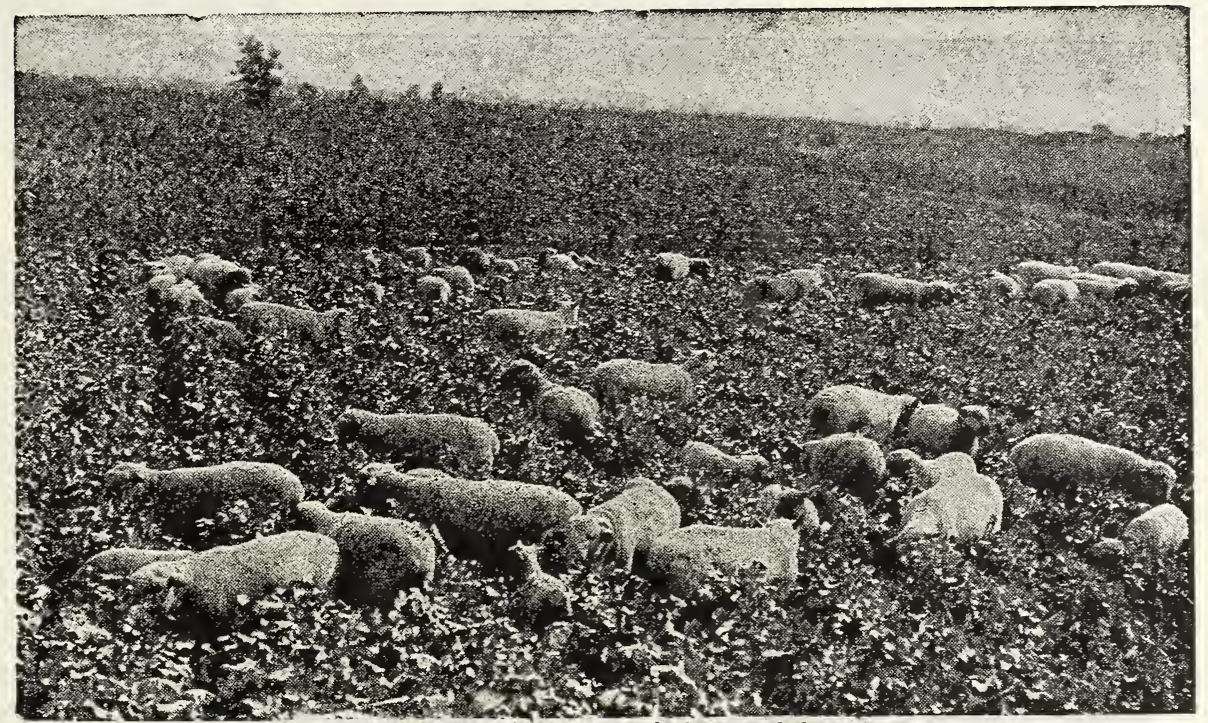

Sheep pastured on rape bring quick returns.

FIELD SEEDS

$\mathbf{P}$ RICES on all farm seeds are subject to market fluctuation. Therefore we cannot give prices in this catalog on field seeds on account of it going to press before January 1 st. We urge you to write us your needs and we will take great pleasure in quoting you our best prices on all our field seeds and will give you all the information we can as to the planting and culture of same.

\section{Sudan Grass}

A sweet heavy-yielding grass; absolutely drougt-proof and grows successfully everywhere sorghums will grow. Livestock of all kinds eat it greedily and for a stock of cattle it will add weight more rapidly than any other variety of sorghum grasses. Yields more pasture per acre than any other annual forage crop.

Sudan Grass can be best described by saying that it has all the good qualities of Johnson Grass, with a lot more of its own added, and while it looks like an extra tall growing strain of Johnson Grass it has not a single bad quality or characteristic of the Johnson Grass, such as the creeping underground root stalks. Sudan is absolutely free from the objectionable root system which makes Johnson Grass so difficult to eradicate. Sudan Grass is an annual and requires reseeding each year. It is no more difficult to get rid of than sorghum, cow peas or other similar crops, and it may be sown, either drilled in cultivated rows $3 \frac{1}{2}$ feet apart, or broadcast. For drilling rows $3 \frac{1}{2}$ feet apart it will require 3 to 6 pounds per acre, depending on the cultivation of the land. Broadcast it should be sown 15 or 20 pounds per acre. The seed should not be sown until the ground is warm in the spring, in this latitude about May 15th is the earliest practical date. The first hay crop will be ready to harvest about 45 to 50 days from date of sowing. The second crop from 30 to 35 days. The third crop from 30 to 35 days. If you wish to save a seed crop from Sudan it will require 80 to 90 days from date of sowing the seed until the seed crop is to be harvested. After threshing, the straw will prove as nutritious as any other variety of sorghum. Sudan may be sown as far north as any other variety of the sorghum family. In many states it is going to supersede millet as a forage crop because it produces so much more tonnage per acre and the quality of the foliage is so much better. Write for prices.

\section{Dwarf Essex Rape}

Where there are hogs there should also be Dwarf Essex Rape Under favorable circumstances, Dwarf Essex Rape is ready for pasture in six weeks from time of sowing. One acre of good rape will carry a dozen pigs for two months. One of the experiment stations found that an acre of Rape produced as much gain on pigs when used for pasture crop along with grain as 56 bushels of corn would produce. In addition to the feeding value of Rape, the hogs are bound to be stronger and gain more rapidly on the Rape pasture than the ones which have been fed on grain alone. A plant with as great feeding value as rape should find a welcome on all farms where hogs are raised. An acre of Rape in the experiment equaled much more than an average acre of corn and the cost of producing was much less, and the cost of harvesting was nothing, as it was done by the hogs. Also fine for chickens and turkeys. Write for prices.

\section{Cow Peas}

Made poor land rich, and rich land more productive. Cow Peas are especially valuable as a "catch crop" for forage or hay and there are many million acres of land in the Middle West that could be improved in productivity by sowing Cow Peas after wheat has been harvested. Cow Peas require from 70 to 90 days to mature a crop of peas, and if the crop is put in the last of June or the first half of July there will be plenty of time for the wheat crop to mature as well as to produce a good hay crop. The same land can be used for seeding wheat again in the fall months.

Whippoorwill-A favorite early maturing variety of medium growth. The seed is reddish brown speckled. Write for prices.

\section{Sorghum or Cane for Forage}

Black Amber-One of the most valuable for ensilage, and is practically sourless when stacked out of doors, and usually can be fed as late as the middle of May following the harvest without deterioration in any respect. We can also recommend it for forage.

Early Orange-Later than either of the Ambers, the stalks shorter and heavier. For forage or ensilage it is first-class. One of the heaviest producers of ensilage of the entire Sorghum 


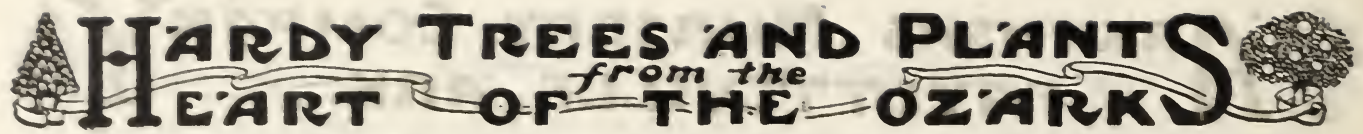

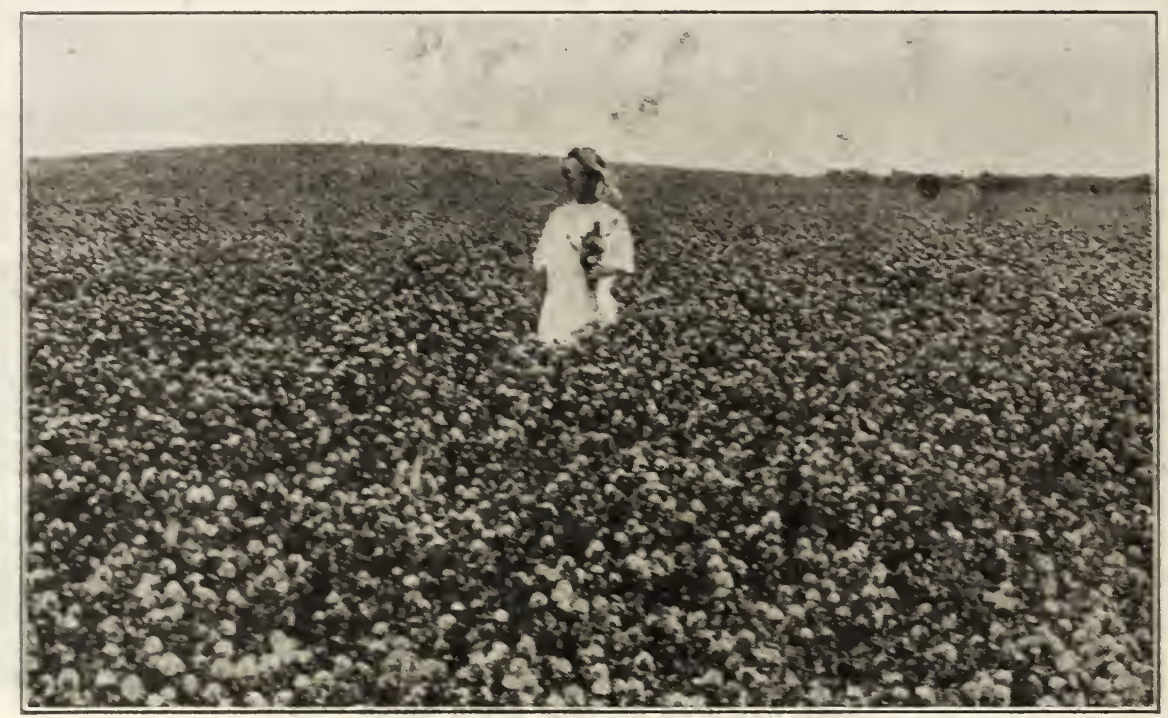

A field of Red Clover.

\section{The Spanish Peanut}

Have been the most popular variety used in the Middle West and Southwest, because most of the acreage deroted to peanuts has been devoted to hog feed and hay. It is the largest producer in pounds per acre, but on account of the small size pods, it costs a little more to harvest it than with the larger podded varieties. The nuts are always very sweet and finely flavored; are more free from undeveloped hernels than any other variety. Write for prices.

\section{Alfalfa or Lucerne}

Too well known to require any detailed description. There is no other plant in existence that is so well known and so useful. Is perennial and lasts from eight to ten years. (The roots penetrate from 10 to 15 feet in the ground. Hard pan or limestone underground is fatal to the plant. Sandy loam with porous underground, so the roots can get to water, is preferable.) Seed can he sown either in fall or spring, at the rate of 15 to 20 pounds per acre. Write for prices.

\section{Clover}

Red Clover (Trifolium Pratense)-Standard Clover for all purposes; makes superior hay, especially if mixed with Tinothy. Grows best on limestone soils. Sow s to 12 pounds per acre. Vrite for prices.

White Dutch Clover-It is very hardy and its dwarf growth makes it desirable for lawns, if sown with Bermuda Grass. Write for prices.

\section{Bermuda Grass}

Very fine for binding loose and dry soils. The habits of this grass is to set noots at each joint that touches the ground, thereby formirs a complete sod. Furnishes excellent pasture. Is decidedly a summer grass, as it does not start oif until ground is thoroughly warm in the spring, and turns to a buff color after killing irost in the fall. We believe this grass will help solve the pasture question during the hot dry summer months. Best time to sow Bermuda is about the last of Febrtary or any time during March. But will not germinate until the ground gets warm. Sow on top of snow or just before a rain of possible.
Also valuable in some sections as a lawn grass. Sow 3 to 5 pounds to the acre. Write for prices.

\section{Timothy}

As a crop to cut for hay. Timothy is probably surpassed by no other grass now cultivated. If sown alone it requires 12 to 18 pounds per acre. It is usually sown with other grasses about onehali to one-third of the above amount Can be sown in either fall or spring. Write for prices.

\section{Red Top or Herd's Grass \\ Fancy solid seed}

This is well adapted to the Southrest. Suitable for meadow and pasture mixture, or for use in lawn making. Adapts itself to any soil, but produces best results on moist, rich soils, where it grows 2 to 216 feet high. Often sown with Timothy and Clover, and outlasts both. Sow 20 to 25 pounds per acre for lawns. For pastures, 8 to 10 pounds per acre. Write for prices. Satisfaction or money back.

We carry in stock other field seeds such as Millet; Seed Oats, Red Rust Proof and Early May; Seed Wheat, Fultz Smooth Head and Fulcaster Bearded: Seed Rye: Sunflower Seed: Seed Corn, Iowa Silver Mine, Iowa Gold Mine, Hickory King, St. Charles White. Write us telling kind and quantity you want and we will quote you our list prices.

We carry in stock insecticides for San Jose Scale, leaf eating insects, blight, potato bugs, plant lice, etc. Also Conkeys and Dr. Hess Poultry Remedies, poultry supplies and spray pumps. Write for kind you want and prices.

\section{Pineyon, Arizona, March 26, 1921.}

received the 100 Strawberry Plants and am glad to say they were in excellent con. dition when they arrived. I am very much pleased with them

$$
\text { H. W. MARSHALL. }
$$

Crown, Texas, March 11, 1921.

I received my order. The trees were all in good shape. Thanking you, I am

$$
\text { A. ROSENEMER. }
$$




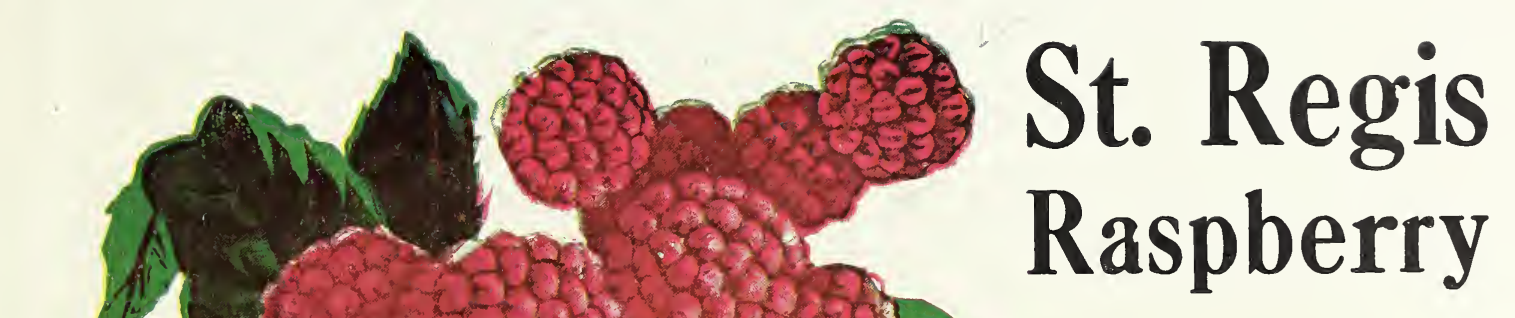

Bears First, Last and All the Time

\section{Raspberries}

For four months, that is what you get when you plant ST. REGIS, the new everbearing variety. They are raspberries of the HIGH. EST GRADE.

THE variety has been aptly, termed "the early 'til late" variety; for it is the first red raspberry to give ripe fruit, while it continues to produce berries without intermission until late in October.

Price each, $15 \mathrm{c} ; 10$ for $\$ 1.00$; 100 for $\$ 6.00 ; 1,000$ for $\$ 40.00$.

\section{SPECIAL OFFER ON Old Time Red Indian Peach}

1 year trees $25 \mathrm{c}$ each; 10 for $\$ 2.00$; 100 for $\$ 15.00$

Old Time Red Indian-Very highly colored, red as blood to the seed, very large. Fruit so large that it would not go into a pint tin cup. There are many strains of Red Indian peaches on the market and a great many are very small and undesirable. Our buds from which our Rea Indian were grown were cut from a tree that by chance was called to our attention away up in the Ozark Mountains. We believe that this strain is the very best of all the strains.

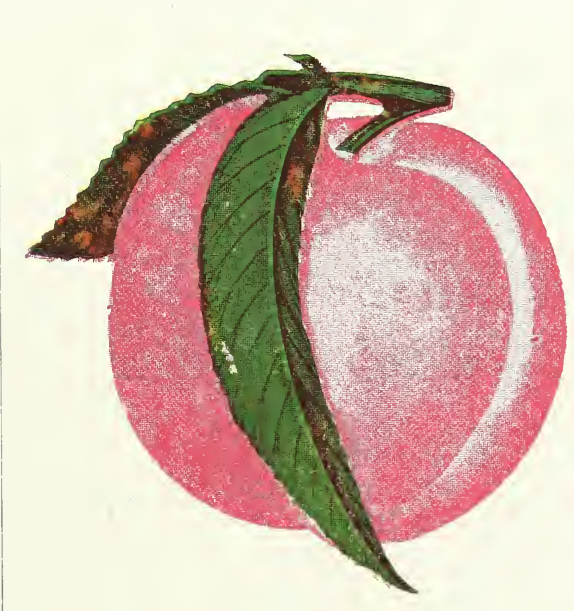




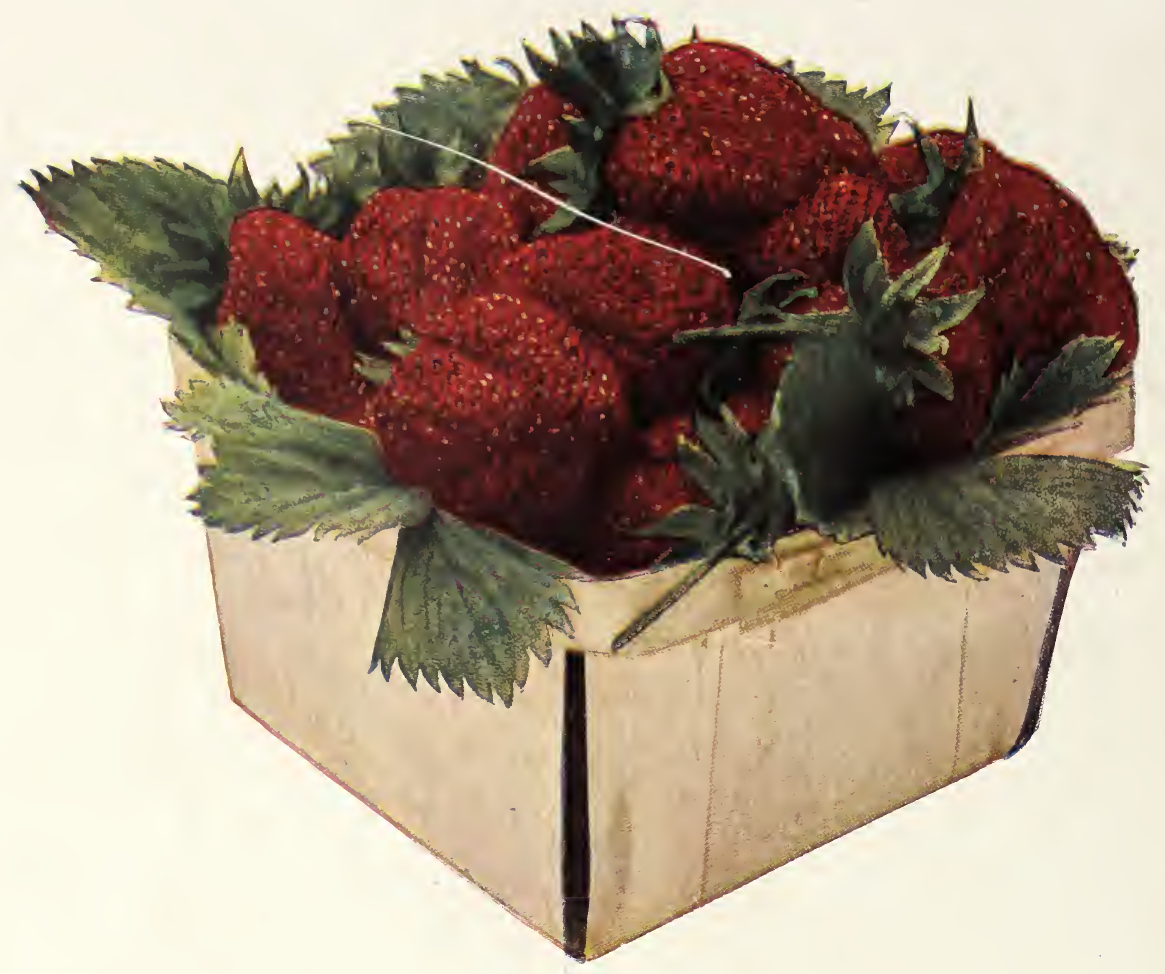

\section{Progressive Everbearing Strawberry}

Wouldn't it be nice to be able to pick Strawberries all summer? Well, that is just what varieties, will produce an abundant crop in Jt is just as easy to grow as the common you can do if you plant this new variety. Iune and then keep right on bearing all sum. mer on the young plants. You can pick ripe Strawberries in increasing quantities from June until October. Of superior quality and the only variety that will produce a crop the first year.

25 for $\$ 1.00 ; 100$ for $\$ 2.00 ; 1,000$ for $\$ 15.00$

\section{Arkansas Beauty Apple}

5 Choice Trees Free with $\$ 15.00$ Order; or 10 Trees Free with $\$ 25.00$ Order

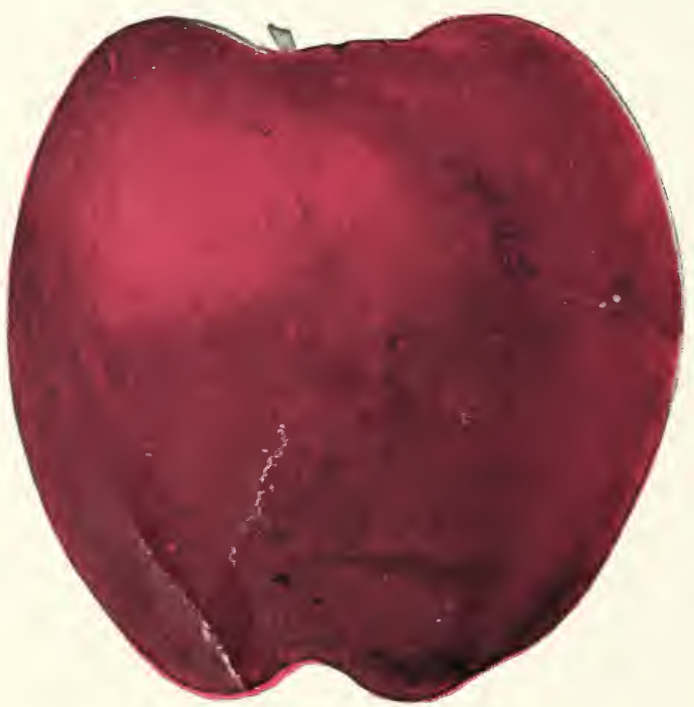

\section{A Fine New Apple}

This famous apple-grown in Arkansas for thirty years, is acknowledged to be superior in many ways to the Jonathan. It ripens earlier and at a time when the demand for a high-class eating apple is greatest. Fine flavored, medium sized, solid red color. This apple is a fine grower and hardy. We have grown a few thousand of these trees this season. Send in your order early, as this offer expires when our limited number of trees are gone.

Price, each, for first class trees, 50c.

"An Apple a Day Keeps the Doctor Away." 